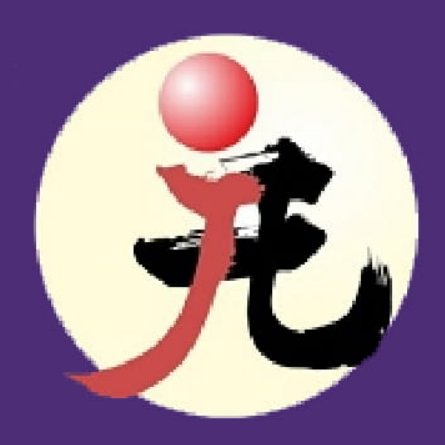

E-ISSח: 2528-5548

Jumal Pendidifean dan Pengajaran Bahasa Jepang

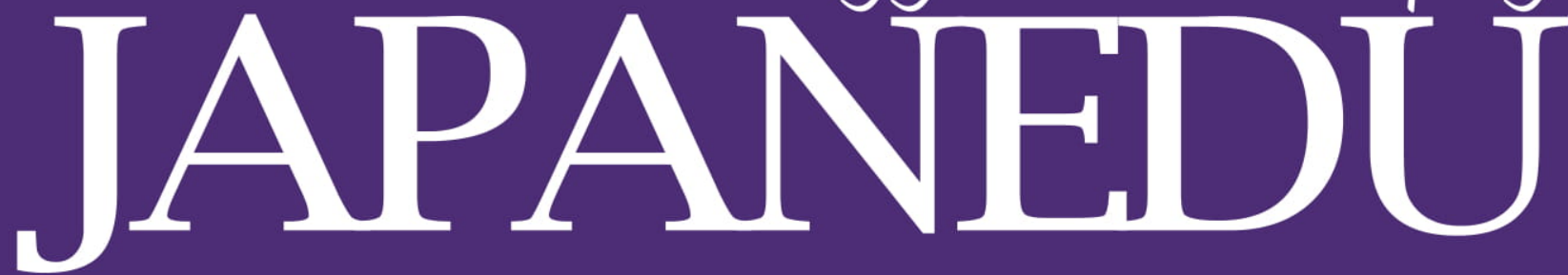

Diterbitkan oleh:

DEPARTEMEN PENDIDIKAN BAHASA JEPANG FAKULTAS PENDIDIKAN BAHASA DAN SASTRA UNIVERSITAS PENDIDIKAN INDONESIA

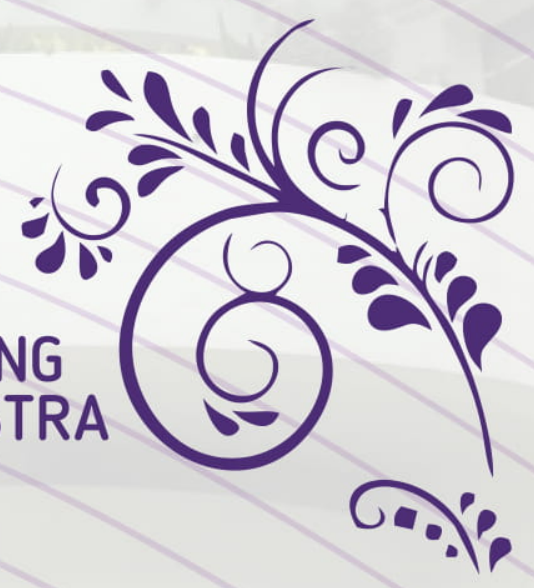




\section{JAPANEDU}

\section{Jurnal Pendidikan dan Pengajaran Bahasa Jepang e-ISSN 2528-5548}

Volume 5, Issue 1, June 2020

JAPANEDU: Jurnal Pendidikan dan Pengajaran Bahasa Jepang is an online, open access peer reviewed journal, which is published twice year every June and December. This journal is for all contributors who are concerned with a research related to Japanese language education studies.

JAPANEDU: Jurnal Pendidikan dan Pengajaran Bahasa Jepang provides a forum for publishing the original reserach articles, paper-based articles and review articles from contributors, related to Japanese culture, Japanese literature and Japanese language teaching/learning, which have never been published before.

\section{Editorial Team}

Editor in Chief

Associate Editor

Advisory

Boards

Editorial Boards and Reviewers
: Nuria Haristiani (Universitas Pendidikan Indonesia)

: Herniwati (Universitas Pendidikan Indonesia)

Via Luviana Dewanty (Universitas Pendidikan Indonesia)
: Didi Sukyadi (Universitas Pendidikan Indonesia)

Ari Arifin Danuwijaya (Universitas Pendidikan Indonesia-University of Adelaide)

\author{
: Kumiko Sakoda (Hiroshima University) \\ Dian Bayu Firmansyah (Universitas Jenderal Soedirman) \\ Nagata Ryota (Hiroshima University) \\ Levent Toksoz (Namik Kemal University) \\ Ishizawa Toru (Tokyo University of Foreign Studies) \\ Syahrur Marta Dwisusilo (Universitas Airlangga) \\ Ismatul Khasanah (Universitas Brawijaya) \\ Lkhagava Ariunjargal (Mongolian National University of Education) \\ Ni Nengah Suartini (Universitas Pendidikan Ganesha) \\ Chevy Kusumah Wardhana (Universitas Negeri Semarang) \\ Inu Isnaeni Sidiq (Universitas Padjajaran) \\ Sudjianto (Universitas Pendidikan Indonesia) \\ Noviyanti Aneros (Universitas Pendidikan Indonesia)
}

\section{Editorial Office:}

Fakultas Pendidikan Bahasa dan Sastra, Universitas Pendidikan Indonesia

J1. Dr. Setiabudhi 229 Bandung 40154 Bandung, Jawa Barat, Indonesia

Email

: japanedu@upi.edu

Website $\quad$ http://ejournal.upi.edu/index.php/japanedu/index 


\section{JAPANEDU}

\section{Jurnal Pendidikan dan Pengajaran Bahasa Jepang}

e-ISSN 2528-5548

Volume 5, Issue 1, June 2020

\section{TABLE OF CONTENTS}

What Makes Difficult to Keep Learning Japanese? Demotivational Factors Affecting on

Indonesian University Students

Junko Yamashita, Hiroshima University

Implementation of Active Knowledge Sharing Strategy in Intermediate Level Dokkai through

Scientific Approach

Feny Oktaviany, Frida Philiyanti, Viana Meilani Prasetio, Universitas Negeri Jakarta

Embbed Dajare Word Play Process in "Shirokuma Cafe"

Talin Salisah, Nani Sunarni, Universitas Padjajaran

Interactive Learning Medium Development for Learning Hiragana and Katakana

Desak Made Sri Mardani, I Wayan Sadyana, Putu Hendra Suputra, Universitas Pendidikan Ganesha

Speech Act Realization on Handbook Mitigation Disaster in Japan

Rd. Januar Radhiya, Asteria Permata Martawijaya, Chou University, STBA YAPARI-ABA Bandung

Chungi Bushido Value in Animation Movie "Sengoku Musou" by Kojin Ochi

Ruditya Yogi Wardana, Ely Triasih Rahayu, Dian Bayu Firmansyah, Hartati, Universitas Jenderal Soedirman 


\title{
What Makes Difficult to Keep Learning Japanese? Demotivational Factors Affecting on Indonesian University Students
}

\author{
Junko Yamashita \\ Graduate School of Education, Hiroshima University, Hiroshima, Japan \\ junko.ymsht@gmail.com
}

\begin{abstract}
A B S T R A C T
Demotivation can negatively influence the learner's attitudes and behaviors, and result in negative learning outcomes. This paper investigates factors contributing to demotivation in learning Japanese as a foreign language in Indonesia, and the relationship between demotivating factors and present proficiencies. A seventeen-item questionnaire was completed by 157 Indonesian university students. As the result of exploratory factor analysis, questionnaire items consequently grouped to four categories: Course difficulty, Speaking anxiety, Devalued learning, and Boredom. The validity of the four-factor structure was verified by the confirmatory factor analysis method. In addition, two-way ANOVA was performed to investigate the relationship between demotivational factors and proficiency level. As a result, statistically significant differences were found between Low and High groups in all the factors, and between Middle and High groups in the factors expect for Devalued learning. In addition, the scores of Speaking anxiety and Boredom consistently scored the highest among the four factors. However, the degree of demotivation was decreased as the learners' Japanese proficiency improved. Findings from this study indicated that teachers should strive to make classes not only less anxious but also more interesting. Moreover, teachers should scaffold learners, especially low proficient beginners to prevent or minimize their demotivation.
\end{abstract}

K E Y W O R D S

Demotivation; Japanese language learning; Learning difficulties; Motivation; Second language learning

First received: 15 May 2020

A R T I C L E I N F O

Available online: 20 June 2020 Final proof accepted: 16 June 2020

\section{INTRODUCTION}

Interest in learning Japanese language grew dramatically in 1980s and it has still kept its popularity over four decades all over the world. According to the result of binary survey conducted by The Japan Foundation (2019), Indonesia ranked the second highest country in number of students who study Japanese in 2018, with more than 700 thousand learners.
Despite the great numbers of Japanese learners, little attention has been given to the factors regarding individual difference in the context of Indonesia. Moreover, in terms of learner's motivation, most of ID researchers only investigate positive aspects and pay little attention to negative ones.

However, Falout, Elwood, and Hood (2009, p.403) believe that language teachers realize "how one highly motivated learner can positively influence the classroom experience and how one 
demotivated learner can have an opposite effect". Demotivation often causes a longer term of negative effect such as low proficiency, less confidence, dissatisfaction, and in the worst cases, a termination of learning (e.g. Gorham \& Christophel, 1992; Kikuchi, 2014; Rose \& Harbon, 2013; Yang, 2011). Thus, it is necessary to clarify the negative effects in order to prevent learners from suffering demotivation when learning a language. Therefore, in this paper, the author attempts to characterise the factors of learning difficulties within Japanese learning and validate a questionnaire item by means of factor analysis, especially focused on the Indonesian context.

\section{LITERATURE REVIEW}

In the field of second language (L2) learning, research on individual differences has had a rich history, starting with Gardner's pioneer work of motivation (e.g. Gardner, 1985). However, only fairly recently researchers begin focusing on negative impacts on language learning such as demotivation. In early study on L2 demotivation, Dörnyei (2001, p.143) defined it as "specific external forces that reduce or diminish the motivational basis of a behavioural intention or an ongoing action". According to Dörnyei (2001), he developed 9 demotivational factors: 1) Teachers' personalities, commitments, competence, and teaching methods. 2) Inadequate school facilities such as large class sizes, unsuitable level of classes or frequent change of teachers. 3) Reduced selfconfidence due to their experience of failure or lack of success. 4) Negative attitude toward the foreign language studied. 5) Compulsory nature of the foreign language study. 6) Interference of another foreign language that pupils are studying. 7) Negative attitude toward the community of the foreign language spoken. 8) Attitudes of group members. 9) Course books used in class. However, Sakai and Kikuchi (2009) claimed a necessity to redefine Dörnyei's original definition as Dörnyei included internal factors such as reducing one's self-confidence or a negative attitude toward the foreign language, which are derived from learners themselves. Later on, most researches include both internal and external forces as a demotivating factor.

Historically, demotivational research has been mainly focused on English learners. For example, Falout, Elwood, and Hood (2009) and Kikuchi (2014) investigated the demotivation of English learning that Japanese university students face, categorizing factors by means of factor analysis. Their results showed that a variety of demotivational factors may affect students' language learning, providing an evidence for reinforcement of Dörnyei's taxonomy.

In the context of Japanese learning, Xu (2018) and Yang (2011) investigated demotivational factors that Japanese learners face by using a quantitative method. They conducted a questionnaire survey with Taiwanese university students (Yang, 2011) and Chinese university student (Xu, 2018). Their results also support Dörnyei's categories, extracting commonly found factors such as inadequate school facilities and reduced self-confidence.

However, these studies were subjected to learners whose native language has a similar writing system to Kanji (Japanese written characters). For example, the factor "unexpected difficulties in Japanese learning" was extracted from the result of $\mathrm{Xu}$ (2018), and it consisted of items such as "I could not expect that Japanese was such a difficult language to learn." This came from the assumption of Chinese learners that Japanese learning is not difficult because Japan also uses Chinese characters. As mentioned in Rose and Harbon (2013), it is widely known that Japanese foreign language learners struggle to master kanji, particularly if their first language uses alphabetical writing system. Thus, it is necessary to increase research of demotivation for countries that use non-Chinese characters.

Moreover, the degree of demotivation is affected by other factors. For instance, Xu (2018) divided learners into two groups by whether they were willing to make Japanese learning their main major before entering to the university, assuming that the degree of willingness to study Japanese affects the perception of demotivation. Although $\mathrm{Xu}$ failed to examine its effect in her research, Sakai \& Kikuchi (2009) uncovered that lessmotivated learners easily feel demotivated, especially in the factor "lack of intrinsic motivation" than more-motivated learners.

At another level, the study from Falout, Elwood, and Hood (2009) revealed that learners' proficiency also affects their perception of demotivation, concluding that those at lower level feel more demotivated regarding English learning compared to middle or high proficiency learners. In this respect, we have to consider the effect of learners' proficiency when examining L2 learning demotivation. 
To sum up, demotivational research on Japanese learning has mainly investigated in countries that use Chinese characters. In order to further explore factors contributing to student demotivation, it is important to elicit data from various learners of Japanese. Thus, this study focuses on Indonesia, which has the highest number of students among countries using nonChinese characters. In addition, as proficiency level also has an effect on demotivation, this study also attempts to specify the difference between high, middle, and low proficiency learners.

\section{RESEARCH METHODS}

\section{Participants}

Participants for this study were 157 Indonesian learners from six universities in Bandung, Yogyakarta, Surabaya, and Malang in Java Island, Indonesia. The students' average age was 20 years and 8 months; 142 were undergraduate students and 15 are graduate students. Among them, more than 90 percent of students took Japanese language or cultural studies as their major subject. According to their response of Japanese Language Proficiency Test (JLPT) acquirement, their proficiency ranged from beginning to advanced levels, as listed in Table 1.

Table 1: Number of students with JLPT acquirement.

\begin{tabular}{|c|c|}
\hline N1 & 5 \\
\hline N2 & 28 \\
\hline N3 & 60 \\
\hline N4 & 32 \\
\hline N5 & 21 \\
\hline N/A & 11 \\
\hline Total & 157 \\
\hline
\end{tabular}

\section{Research Instruments}

Based on the previous studies on demotivation in second language learning (Falout, Elwood, \& Hood, 2009; Kikuchi, 2014; Xu, 2018; Yang, 2011), 30 items were selected to characterize learning demotivation. As mentioned in the previous section, items asking about external factors (e.g. teacher, class size or classroom facility) are excluded from the survey.
The final version of the questionnaire used in the research consisted of 35 items, of which 30 were 7-point Likert-scale items that aimed to measure the factors in learning difficulties, and the rest were questions asking students' background concerning the languages they use on a daily basis, their age, their academic major, their proficiency of Japanese (JLPT), and the length of studying Japanese.

Since the questionnaire items in previous studies were written in Japanese expect for Falout, Elwood, and Hood (2009), they were translated into Bahasa Indonesia. Two Indonesian graduate students (N1 acquired) helped for the translation.

\section{Research Procedures}

The questionnaire survey was administered online. Teachers of the class distributed a URL to the students via social media, mentioning that the participation for the survey was anonymous and voluntary. The online website was set as free access from August to the end of September, 2019. The data from 157 learners was collected during this period.

\section{Data Analysis}

Before analysing the collected data, descriptive statistics were carried out to describe the main features of each item. During this process, 7 items were excluded from the scale because they did not show any distinguishing features among participants in terms of the measured behavior.

The data was analysed in the following steps. At first, in order to explore the characteristic of demotivational factors, an exploratory factor analysis was performed. In addition, internal consistencies of the instruments were examined with the value of Cronbach's alpha.

Next, a confirmatory factor analysis was conducted to measure the validity of the factor structure that was obtained from the previous analysis. To assess whether the data fit the structured model, the following fitting indexes were used: the goodness of fit index (GFI), incremental fit index (IFI), normed fit index (NFI), the Tucker-Lewis coefficient (TLI), the comparative fit index (CFI), and root mean square error of approximation (RMSEA).

Lastly, a two-way analysis of variance (ANOVA) was conducted to examine the effect of proficiency level on four demotivational factors. The subscale scores of each factor were calculated 
for the analysis. Based on their responce, students were devided into three groups: Low, Middle, and High proficiencies. N4 or N5 holders and eleven students with no requirement were grouped as Low $(n=64)$, N3 holders as Middle $(n=60)$, and $\mathrm{N} 2$ or N1 holders as High $(n=33)$. The "no requirement" answer that eleven participants responded with means that they have learned Japanese for less than one year and their proficiency level was adequate to beginner. Therefore, they were categorized in the Low group.

The computer programs used for each data analysis were R (version 3.5.0), SPSS AMOS (version 26), and SPSS (version 26), respectively.

\section{RESULTS}

\section{Characteristics of Demotivational Factors}

An exploratory factor analysis was carried out using a maximum likelihood estimation with promax rotation. A four-factor-solution was imposed, based on the scree plot and theoretical conceptualizations. The four-factor structure explained approximately $70 \%$ of the total variance, which was quite high, to characterize demotivational factors in L2 Japanese learning. Table 2 indicates the pattern structure of the factor analysis with item loadings (See Appendix for items written in Japanese and Bahasa Indonesia).

Items loading on Factor 1 concern the inappropriate level of the learning content and pace of the courses, and was therefore named Course difficulty, a common factor of demotivation found in the L2 learning field (Falout, Elwood, \& Hood, 2009; Kikuchi, 2014; Xu, 2018).

Factor 2 was labeled as Speaking anxiety, reflecting perceived anxiety and nervousness, being afraid of speaking Japanese, and being afraid of making mistakes in front of teachers or classmates. Yang's (2011) study also described this factor as demotivator to learning Japanese.

Factor 3 was composed of items describing the negative consequence toward studying Japanese, or losing the value of studying, therefore it was named Devalued learning. Fatmawati (2016) stressed the importance of learners finding the

Table 2: Factor loading (17 items).

\begin{tabular}{|c|c|c|c|c|c|c|c|c|}
\hline & & $F 1$ & $F 2$ & $F 3$ & F4 & $h 2$ & $M$ & $\overline{S D}$ \\
\hline \multicolumn{9}{|c|}{ Factor 1 Course difficulty $(\alpha=.89)$} \\
\hline 1 & I often find it difficult to understand the content of the class. & .93 & -.07 & -.02 & -.01 & .41 & 3.51 & 1.49 \\
\hline 2 & The teacher's speaking speed is too fast to understand. & .92 & .02 & -.24 & -.08 & .22 & 2.99 & 1.53 \\
\hline 3 & I often find it difficult to keep up with the pace of classes. & .84 & -.01 & .08 & .00 & .21 & 2.96 & 1.51 \\
\hline 4 & I can't complete homework or assignments because I have a lot of them. & .69 & -.08 & .03 & -.01 & .56 & 2.82 & 1.43 \\
\hline 5 & I feel that my grades do not improve even if I try hard. & .55 & .04 & .09 & .10 & .51 & 3.41 & 1.56 \\
\hline 6 & When I attempt a difficult task, I soon get tired and quit trying. & .52 & .04 & .12 & .12 & .50 & 3.18 & 1.44 \\
\hline \multicolumn{9}{|c|}{ Factor 2 Speaking anxiety $(\alpha=.90)$} \\
\hline 7 & When speaking Japanese, I get nervous and can't speak well. & -.05 & .96 & -.04 & .00 & .28 & 4.12 & 1.61 \\
\hline 8 & I get nervous when speaking Japanese in front of everybody. & -.15 & .91 & -.05 & .09 & .17 & 4.06 & 1.52 \\
\hline 9 & I am embarrassed making mistakes in my classes. & .06 & .79 & .04 & -.20 & .39 & 3.93 & 1.61 \\
\hline 10 & I am afraid of being asked questions from teachers or Japanese people. & .25 & .66 & .04 & -.01 & .30 & 3.67 & 1.60 \\
\hline \multicolumn{9}{|c|}{ Factor 3 Devalued learning $(\alpha=.88)$} \\
\hline 11 & I often find it meaningless to study Japanese. & -.04 & -.10 & .96 & -.05 & .26 & 2.20 & 1.39 \\
\hline 12 & I lost my goals or purposes of studying Japanese. & -.08 & .02 & .92 & -.03 & .27 & 2.50 & 1.52 \\
\hline 13 & I don't think that Japanese would be useful in the future. & -.06 & .09 & .74 & .13 & .45 & 2.05 & 1.34 \\
\hline 14 & I am less interested in studying Japanese. & .19 & -.04 & .67 & -.08 & .32 & 3.03 & 1.64 \\
\hline \multicolumn{9}{|c|}{ Factor 4 Boredom $(\alpha=.88)$} \\
\hline 15 & I got tired of every day's monotonous study. & -.04 & -.04 & -.05 & .97 & .18 & 3.76 & 1.53 \\
\hline 16 & I feel that language learning is monotonous and boring. & .00 & -.04 & .00 & .96 & .11 & 3.55 & 1.55 \\
\hline \multirow[t]{7}{*}{17} & I soon get tired when I am doing Japanese homework and assignments. & .09 & .16 & .07 & .58 & .42 & 3.96 & 1.67 \\
\hline & eigenvalues & 7.82 & 2.04 & 1.55 & 1.26 & & & \\
\hline & $\%$ of variance & 21.4 & 16.9 & 16.8 & 13.5 & & & \\
\hline & factor correlations $F 1$ & - & - & - & - & & & \\
\hline & $F 2$ & -.37 & - & - & - & & & \\
\hline & $F 3$ & .56 & -.55 & - & - & & & \\
\hline & $F 4$ & .60 & -.49 & .63 & - & & & \\
\hline
\end{tabular}


value of learning Japanese, described as "investment" in her research, which affect their motivations. Meanwhile, results from Xu (2018) and Yang (2011) did not contain this factor.

The last factor, Factor 4 included items describing learners' perception of having lost the interests to learn Japanese or getting bored of Japanese study, therefore was labeled as Boredom. Although prior works also mentioned feeling of boredom with class in the field of educational psychology (e.g. Gorham \& Christophel, 1992), no study categorized it as a factor in L2 learning. The values of Cronbach's alpha coefficients were quite high.

\section{Validity of the Factor Structure}

In order to measure the validity of the factor structure obtained from the previous analysis, a confirmatory factor analysis was performed (See Figure 1). The analysis provided a satisfactory validity for measuring Indonesian university learners' demotivation regarding L2 Japanese learning $\left(\chi^{2}=190.914, d f=105, \mathrm{GFI}=.878\right.$, IFI $=.954, \mathrm{NFI}=.902, \mathrm{TLI}=.939, \mathrm{CFI}=.953$, RMSEA = .072). Although the GFI index indicated a less adequate fit, other indexes (i.e. IFI, NFI, TLI, and CFI) indicated a good model fit. The RMSEA value was 0.072 which is larger than an adequate value at 0.05 , but still meets the acceptance level of less than 1.00. Overall, these statistical results suggest that the structured model explain the data well. In other words, L2 Japanese learners' demotivation is composed of the four factors of Course difficulty, Speaking anxiety, Devalued learning, and Boredom.

\section{Comparison on Proficiency Level}

Two-way ANOVA was performed to investigate the relationship between proficiency level and demotivational factors. As mentioned in the data analysis section, the participants were grouped into three categories regarding proficiency: Low $(n=64)$, Middle $(n=60)$, and High $(n=33)$. The mean scores and standard errors of items loading on each four-factor are shown in Table 3. Overall, the mean scores of Factor 2 are relatively high $(4.28,3.94,3.30$, respectively), followed by Factor 1 and 4 . The mean scores of Factor 3 were the lowest in all groups $(2.73,2.38,2.04$, respectively).

The result of ANOVA showed statistically significant differences in the main effect of groups, the main effect of demotivational factors, and the interactional effect between the groups and the factors. A post-hoc analysis with Bonferroni adjustments revealed statistically significant differences of scores among three groups in all of the factors.

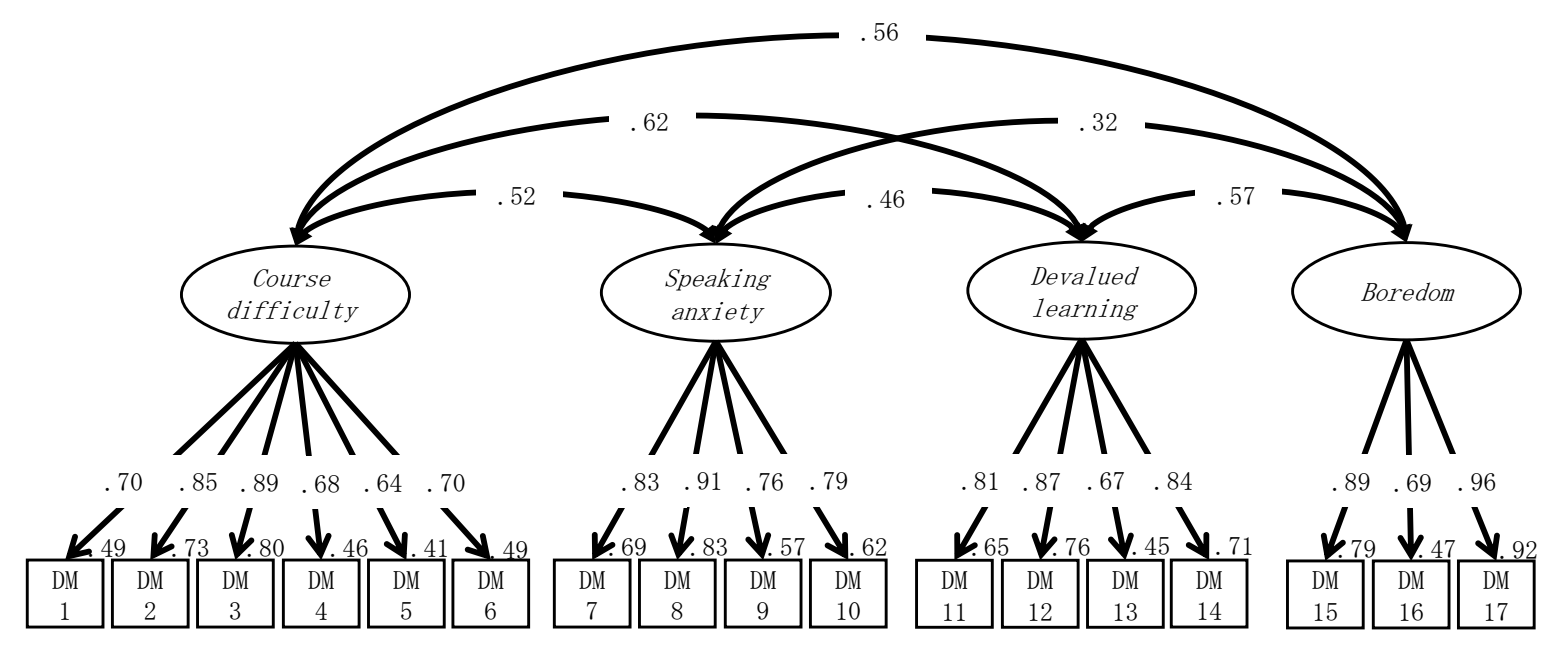

Figure 1: The final model of the demotivational structure on L2 Japanese learning. 
First, statistically significant differences were found between Low and High for all of the factors. As Table 3 indicates, the factors which incurred the largest difference in means, with statistical significance at the $p<.005$ level, was Factor 1: Course difficulty. This factor showed the largest difference at 1.20 between low and high proficiency learners.

Table 3: Means and Standard Deviations of 4 Japanese learning demotivational factors.

\begin{tabular}{lccc}
\hline & $\begin{array}{c}\text { Low } \\
(n=64)\end{array}$ & $\begin{array}{c}\text { Middle } \\
(n=60)\end{array}$ & $\begin{array}{c}\text { High } \\
(n=33)\end{array}$ \\
\hline $\begin{array}{l}\text { Course difficulty } \\
(k=6)\end{array}$ & 3.50 & 3.24 & 2.30 \\
$(1.19)$ & $(1.01)$ & $(1.16)$ \\
$\begin{array}{l}\text { Speaking anxiety } \\
(k=4)\end{array}$ & 4.28 & 3.94 & 3.30 \\
$\begin{array}{l}\text { Devalued learning } \\
(k=4)\end{array}$ & $(1.48)$ & $(1.14)$ & $(1.41)$ \\
$\begin{array}{l}\text { Boredom } \\
(k=3)\end{array}$ & $(1.43)$ & 2.38 & 2.04 \\
\hline & 3.80 & 4.03 & $(0.89)$ \\
& $(1.43)$ & $(1.27)$ & $(1.55)$ \\
\hline
\end{tabular}

In addition, there were also significant differences between Middle and High for Factor 1, Factor 2, and Factor 4. In other words, there is a huge difference in the perception of Japanese learning demotivation between low, middle proficiency learners and high proficiency learners. For Factor 3, there was no significant difference between Middle and High. In this respect, their sense of value on Japanese learning does not change depending on proficiency level compared to other factors.

Furthermore, as illustrated in Figure 2, there were no statistically significant differences between Low and Middle group. In other words, the pattern in both Low and Middle group have a similar tendency, except for Factor 4. In Factor 4 , the score in Middle group was higher than Low, whereas Low groups got lower scores for the rest of factors. Therefore, intermediate level learners feel less stimulated and become bored when learning Japanese, while beginners tend to feel bored with their study less often.

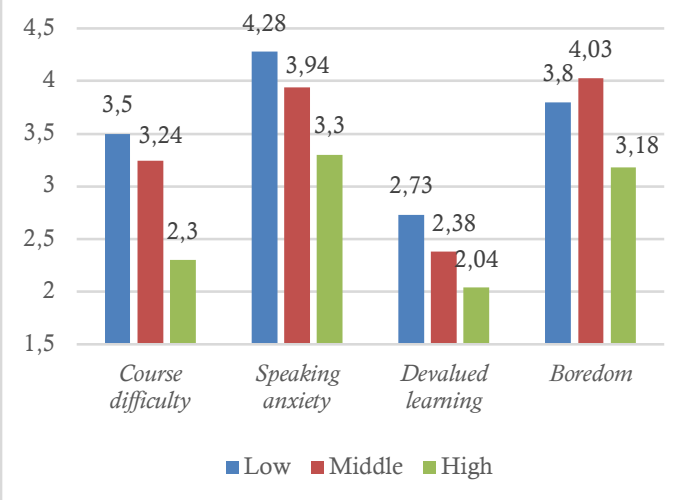

Figure 2: Means of each demotivational factor in three groups.

\section{CONCLUSIONS}

The aim of this study was to investigate demotivational factors with regarding to learning Japanese in Indonesia, and the relationship between demotivating factors and present proficiencies. As a result of exploratory factor analysis, the four-factor structure was extracted: Course difficulty, Speaking anxiety, Devalued learning, and Boredom. This structure explained approximately $70 \%$ of demotivational factors in L2 Japanese learning. From the analysis, the structure has satisfactory values of reliability and validity, which reinforces a confirmation of the results.

Comparing the previous researches (Xu, 2018; Yang, 2011) in the context of L2 Japanese learning, some new factors (Devalued learning, and Boredom) have been added. Although the former factor was extracted from the analysis, the score was the lowest among the demotivational factors. As mentioned in Fatmawati (2016), learning Japanese has a strong value on one's career, compared to English which has become a global language. Japanese learners seem to make a clear vision and ascribe high value to Japanese learning when majoring in Japanese studies in universities. However, if students find it meaningless to study Japanese, it can negatively influence their attitudes or behaviors, and sometimes it results in giving up and quitting learning. From pedagogical perspectives, teachers should provide opportunities to make students think about the reasons why they started learning Japanese or long term goals such as a 
career with Japanese language skill. By making students more responsible for their own learning, students may be less likely to blame their shortcomings on teachers or other external forces (Peters, 2013). The latter factor, Boredom, has also been recognized as a demotivational factor. During the long-term process of learning, students may easily feel bored of learning as they get accustomed to it, particularly intermediatelevel students. However, the degree of boredom incrementally decreased as they become to an advanced level. Although teachers need to make classes more interesting, understanding the feature of demotivation and scaffold learners enable an increase of continuity in L2 leaning.

Among the four factors, results showed statistically significant differences among the three proficiency groups, especially the scores in Factor 2 and Factor 4 which were higher when compared to the other two factors. This finding suggests that students find it more difficult to maintain their motivation when facing anxiety and boredom throughout their studies. Thus, in order to prevent or minimize their demotivation, it is necessary for teachers to pay more attention to students' perceptions of classes and devise each class in not only 'less-anxious' but also 'more-interesting' way.

Considering the various findings presented above, the influence of demotivation is too significant to ignore. Although Indonesian university students take Japanese as a major study, when being faced with inappropriate level of learning courses, feeling anxious in speaking in class, losing the values of learning Japanese, or feeling bored of classes, they are at risk of becoming demotivated. Teachers need to think of learner attitudes and their impact on Japanese learning, and at the same time, need to find various of ways to prevent or minimize learners' demotivation.

\section{REFERENCES}

Dörnyei, Z. (2001). Teaching and researching motivation. Harlow: Longman.

Falout, J., Elwood, J., \& Hood, M. (2009). Demotivation: Affective states and learning outcomes. System, 37(3), 403-417.

Fatmawati, D. (2016). 高等教育機関における日本語 学習の 動機づけの変化に関する一考察—イン ドネシア人日本語学習者の語りからー [A study on the motivational change of Japanese learning in higher educational institution: Narratives of Indonesian Japanese learners]. Transcommunication, 3(2), 211-231.

Gorham, J., \& Christophel, D. (1992). Students' perception of teacher behaviours as motivating and demotivating factors in college classes. Communication Quarterly, 40, 239-252.

Kikuchi, K. (2014). 英語学習動機の減退要因の探求 一日本人学習者の調査を中心に [Demotivators in English Language Learning: Perspectives from Japan]. Tokyo: Hitsuji Shobo.

Peters, R. (2013). Demotivation: A discussion of factors that affect the attitudes of Japanese postsecondary students of English. The Bulletin of St. Margaret's, 45, 41-48.

Rose, H., \& Harbon, L. (2013). Self-regulation in second language learning: An investigation of the kanji-learning task. Foreign Language Annals, 46(1), 96-107.

Sakai, H., \& Kikuchi, K. (2009). An analysis of demotivators in the EFL classroom. System, 37(1), 57-69.

The Japan Foundation (2019). Preliminary survey report on Japanese-language education abroad $2018 . \quad$ Retrieved from https://www.jpf.go.jp/j/about/press/2019/d1/20 19-029-02.pdf

Xu, Q. (2018). 中国における日本語専攻学習者の専 攻の振り分けによる動機減退要因の比較 [Japanese Language Learners in China: A comparison of demotivation factors between students who voluntarily choose japanese language and those who study through major transfers]. $日$ 本語教育[Journal of Japanese language teaching], 169, 46-61.

Yang, D. (2011). 台湾の日本語主専攻学習者の学習 困難度と継続ストラテジーとの関連 [The correlation between learning difficulties and perseverance strategies of japanese language majors in taiwan], 人間文化創成科学論叢[Journal of the Graduate School of Humanities and Sciences], 14, 147-155.

\section{APPENDIX}

Factor 1: Course Difficulty

1. I often find it difficult to understand the content of the class.

授業の内容が難しくて理解できないこ とがよくある

Sering tidak mengerti materi perkuliahan karena sulit.

2. The teacher's speaking speed is too fast to understand. 
先生の話すスピードが速くて理解でき ないことが多い

Sering tidak mengerti pelajaran karena cara bicara dosen yang cepat.

3. I often find it difficult to keep up with the pace of classes.

授業の進むスピードが速くてついてい けないことが多い

Sering tertinggal pelajaran kerena pembelajaran di perkuliahan sangat cepat.

4. I can't complete homework or assignments because I have a lot of them.

宿題や課題が多くて全て終わらせられ ないことが多い

Sering tidak bisa menyelesaikan tugas atau PR karena terlalu banyak.

5. I feel that my grades do not improve even if I try hard.

努力してもなかなか成績が上がらない と感じる

Merasa nilai tidak membaik padahal sudah berusaha.

6. When I attempt a difficult task, I soon get tired and quit trying.

宿題や課題に取り組んでも，難しかっ たらすぐに諦めてしまう

Meskipun berusaha mengerjakan tugas atau $P R$, tetapi mudah menyerah jika menemukan kesulitan.

Factor 2: Speaking anxiety

7. When speaking Japanese, I get nervous and can't speak well.

日本語を話すときは，緊張して思った ように上手く話せない

Ketika berbicara Bahasa Jepang, saya gugup sehingga tidak bisa berbicara dengan lancar.

8. I get nervous when speaking Japanese in front of everybody.

他の学生や先生の前で日本語を話さな ければならないと緊張してしまう

Saya gugup jika harus bicara Bahasa Jepang di depan guru dan mahasiswa yang lain.

9. I am embarrassed making mistakes in my classes.

クラスのみんなの前で間違えることが 恥ずかしい

Saya malu jika salah di depan teman-teman sekelas.

10. I am afraid of being asked questions from teachers or Japanese people.
先生や日本人に日本語で質問されると, とても不安になる

Saya merasa khawatir jika ditanya dalam Bahasa Jepang oleh orang Jepang atau dosen.

Factor 3: Devalued learning

11.I often find it meaningless to study Japanese.

日本語を学ぶ必要性が分からなくなっ た

Saya jadi tidak paham apa pentingnya belajar Bahasa Jepang.

12. I lost my goals or purposes of studying Japanese.

私には日本語を勉強する目標や理由が 無い

Saya tidak memiliki alasan dan target dalam belajar Bahasa Jepang.

13. I don't think that Japanese would be useful in the future.

日本語を学んでも将来日本語を使わな いと思う

Saya merasa meskipun saya belajar Bahasa Jepang, tidak akan terpakai di masa depan.

14. I am less interested in studying Japanese. 日本語の学習に対する興味が薄くなっ てきた

Minat untuk belajar Bahasa Jepang semakin menipis.

Factor 4: Boredom

15. I got tired of every day's monotonous study.

毎日の単調な学習に飽きてしまった Bosan dengan pembelajaran setiap hari yang monoton.

16. I feel that language learning is monotonous and boring.

言語の学習は，毎日単調でつまらな いと感じる

Merasa pembelajaran bahasa sangat monoton tiap harinya sehingga membosankan.

17. I soon get tired when I am doing Japanese homework and assignments.

日本語の課題や勉強に取り組んでも, すぐ飽きてやめてしまう

Meskipun berusaha mengerjakan tugas atau $P R$, tetapi cepat merasa bosan. 


\title{
JAPANEDU: \\ Jurnal Pendidikan dan Pengajaran Bahasa Jepang \\ http://ejournal.upi.edu/index.php/japanedu/index
}

\section{Implementation of Active Knowledge Sharing Strategy in Intermediate Level Dokkai through Scientific Approach}

\author{
Feny Oktaviany, Frida Philiyanti, Viana Meilani Prasetio \\ Program Studi Pendidikan Bahasa Jepang, Universitas Negeri Jakarta, Rawamangun, Jakarta Timur, Indonesia \\ fenyo210@gmail.com
}

\begin{abstract}
A B S T R A C T
This study aims to determine the effectiveness and to find out the advantages and disadvantages of the Active Knowledge Sharing strategy through a scientific approach in the Dokkai. In learning Japanese, learners often encountered difficulties in reading comprehension or Dokkai. Based on a questionnaire, the difficulties including reading kanji, followed by vocabulary competence and grammar competence. On the other hand, the time limitation in class cause problems of learning method which teacher rarely provide an introduction step to students in the form of questions or vocabulary exercises related to the reading material they will deal with. To overcome this problem, we need a learning strategy that emphasize the cooperative learning among students to achieve the objective of comprehending a reading. We chose the strategy initiated by Silberman (2013), namely Active Knowledge Sharing, as a good way to introduce students to the subject matter that will be learned. In addition, by monitoring how students solving each other's problems in team, teacher can evaluate how much knowledge they have. In this study a scientific approach is complemented to support the active learning in this strategy. The study conducted using an experimental method with pretest and posttest design. The sample are 38 students of fifth semester students who take Dokkai III course. Based on the analysis of research data, it found that the Active Knowledge Sharing strategy through a scientific approach is effective in learning Dokkai III. The advantages are that students who are initially passive become actively participate in learning and students can also answer the meaning of vocabulary without depending on dictionary or smartphones, and students are encouraged to help each other in solving problems which help students to comprehend the contents of reading easier and faster. However there are the disadvantages of this strategy such as inability to enhance student's critical thinking and less suitable for students who are more focused if studying alone.
\end{abstract}

\begin{tabular}{c}
$\frac{\text { K E Y W O R D S }}{\text { Active knowledge sharing strategy; Dokkai; Scientific approach }}$ \\
\hline A R T I C L E I N F O \\
First received: 22 March 2020 Available online: 20 June 2020 proof accepted: 11 June 2020
\end{tabular}

\section{PENDAHULUAN}

Dalam mempelajari bahasa asing, pembelajar sesekali menemukan kesulitan dalam memahaminya. Khususnya ketika belajar untuk memahami bacaan berbahasa asing di kelas. Karena bahasa Jepang merupakan bahasa asing, peneliti menemukan bahwa terdapat kendala atau kesulitan pada pembelajar bahasa Jepang, khususnya mahasiswa semester 6 yang mengikuti mata kuliah Dokbun IV. Kesulitan tersebut dapat diketahui dari hasil angket yang disebarkan pada 25 responden. Hasilnya adalah dalam tiga peringkat, kesulitan paling utama yang dialami mahasiswa adalah membaca kanji, diikuti kosakata, lalu tata bahasa. Dalam proses pembelajaran juga ditemukan kendala dari segi waktu, serta pengajar jarang memberikan pengantar kepada mahasiswa berupa pertanyaan-pertanyaan atau latihan kosakata yang terkait dengan bahan bacaan yang akan dipelajari.

Untuk mengatasi masalah tersebut, dibutuhkan suatu cara yang diharapkan dapat mempermudah 
mahasiswa saat mempelajari Dokkai serta membuat proses pembelajaran Dokkai menjadi efektif. Maka dari itu, peneliti beranjak dari pembelajaran model, pendekatan, strategi, metode, dan teknik dalam pembelajaran. Menurut Sagala (2010, p.175), model adalah "kerangka konseptual yang digunakan sebagai pedoman dalam melakukan kegiatan". Rusman (2014) menyampaikan perbedaan strategi dan metode, dimana strategi menunjukkan pada sebuah perencanaan untuk mencapai suatu tujuan. Sedangkan metode adalah cara yang dapat digunakan untuk melaksanakan strategi yang telah disusun dalam bentuk kegiatan. Dan yang terakhir, menurut Gerlach dan Ely (dalam Uno, 2008) teknik adalah jalan, alat, atau media yang digunakan oleh guru untuk mengarahkan kegiatan peserta didik ke arah tujuan yang ingin dicapai. Dari pendapatpendapat ahli di atas, peneliti mempertimbangkan untuk menggunakan strategi dan pendekatan untuk mata kuliah Dokkai III.

Strategi yang digunakan oleh peneliti adalah strategi Active Knowledge Sharing. Strategi ini pernah diujicobakan dalam penelitian terdahulu. Tidak hanya pembelajaran sejarah, seperti contoh yang disebutkan pada buku Silberman (2013), tetapi, ternyata dapat diterapkan pada pembelajaran bahasa. Zen (2014) mengujicobakan strategi ini pada pembelajaran kosakata bahasa Arab dan hasil menunjukkan bahwa terdapat efektifitas terhadap peningkatan kemampuan kosakata siswa. Penelitian ini pun pernah diujicobakan oleh Arini (2012) pada pembelajaran choukai (menyimak) bahasa Jepang di tahun 2012. Hasilnya terbukti efektif dalam pembelajaran choukai. Karena masalah yang ditemukan di lapangan adalah pembelajaran Dokkai, maka peneliti ingin mengujicobakan apakah strategi ini dapat memecahkan masalah pembelajaran Dokkai.

Strategi Active Knowledge Sharing termasuk dalam strategi pembelajaran aktif yang digagas oleh Silberman (2013). Menurut Silberman (2013), Active Knowledge Sharing adalah cara yang baik untuk mengenalkan siswa pada materi pelajaran yang akan diajarkan pada hari itu. Strategi ini juga dapat digunakan untuk menilai tingkat pengetahuan siswa sambil melakukan kegiatan pembentukan tim untuk saling membantu menyelesaikan masalah. Disebutkan pula bahwa cara ini cocok untuk segala ukuran kelas dengan materi pelajaran apapun.

Pendekatan yang digunakan peneliti adalah pendekatan saintifik. Pendekatan ini mulai sering digunakan sejak munculnya kurikulum 2013, kurikulum dengan tujuan membuat siswa lebih aktif dalam belajar. Menurut Hosnan (2014) pendekatan saintifik adalah proses pembelajaran yang dirancang agar peserta didik secara aktif mengkonstruk konsep, hukum atau prinsip melalui tahapan-tahapan mengamati, merumuskan masalah, merumuskan hipotesis, mengumpulkan data, menganalisis data, menarik kesimpulan dan mengomunikasikan konsep, hukum atau prinsip yang telah ditemukan.

Tingkat membaca mahasiswa semester 5 Program Studi Pendidikan Bahasa Jepang salah satu universitas negeri di Jakarta masuk ke dalam kategori membaca kritis. Karena indikator mata kuliah Dokkai adalah di dalam bacaan yang relatif panjang, mahasiswa diharapkan dapat mengumpulkan informasi mengenai isu-isu spesifik yang berkenaan dengan tema bacaan, dapat menemukan inti dari kalimat argumentatif, dan dapat menarik kesimpulan dari sebuah teks argumentatif. Dikaitkan dengan pendapat Tarigan dalam Pandawa (2009, p.9) bahwa kemampuan membaca kritis merupakan "kemampuan pembaca untuk mengolah bahan bacaan secara kritis dan menemukan keseluruhan makna bahan bacaan, baik makna tersurat, maupun makna tersirat." Oleh karena itu, dalam mata kuliah Dokkai III, mahasiswa sebagai pembaca melatih kemampuan membaca kritis supaya dapat memahami makna bacaan yang panjang, baik secara tersirat maupun tersurat. Istilah membaca untuk memaknai bacaan sesuai dengan makna dalam dokkai yang didefinisikan oleh Mizutani (2005, p.747)，「読解とは文字で書かれた情報を読んで 理解することである。(Dokkai towa moji de kakareta jouhou wo yonde rikai suru koto de aru )」, yang memiliki arti bahwa membaca pemahaman adalah membaca lalu memahami informasi yang tertulis pada huruf.

Dalam pelaksanakan membaca kritis dengan bacaan bahasa Jepang, ditemukan kendala seperti belum mengetahui arti kosakata. Ditambah lagi terdapat tulisan kanji. Seperti masalah yang telah dipaparkan diawal, bahwa permasalah mahasiswa dalam mempelajari Dokkai adalah Kanji dan kosakata. Kedua hal itu memiliki keterkaitan yang sejalan. Soedarso (1994) yang mengatakan bahwa jika membaca teks berbahasa asing, banyak pembaca yang seringkali membuka kamus untuk mengetahui artinya. Kegiatan ini sering terlihat di dalam kelas. Padahal, kegiatan tersebut menjadi masalah karena mengganggu konsentrasi dan membacanya pun jadi lambat karena sering membuka kamus. Cara tersebut dinilai kurang efektif dan kadang dari sudut pandang mahasiswa sebagai pembaca, walaupun mengetahui arti dari kosakata yang ada pada bacaan tersebut, masih merasa terkendala dalam memahami bacaan. Hal ini disebabkan penggunaan kosakata bahasa Jepang yang bervariasi, dipengaruhi oleh konteks tata bahasa dan kanji yang digunakan pada bacaan tersebut. Supaya mahasiswa tidak kesulitan sendiri dalam mempelajarinya, maka alangkah baiknya jika mahasiswa saling membantu untuk mencapai tujuan, yaitu memahami bacaan. Selain dapat memudahkan, 
hal ini dapat mengefisiensikan waktu pembelajaran di kelas. Dengan kerjasama yang dilakukan, seperti saling mengemukakan pendapat, mengkritisi isi bacaan, maka diharapkan seluruh mahasiswa dapat memahami bacaan dengan baik. Hal tersebut didukung oleh pendekatan saintifik, karena salah satu kegiatannya adalah menyampaikan hasil diskusi di kelas.

Oleh karena itu, dengan menggunakan strategi dan pendekatan tersebut, peneliti memiliki harapan untuk membuat siswa lebih aktif dalam menyampaikan ide-idenya dalam pembelajaran Dokkai. Karena kompetensi dasar yang harus dicapai adalah mahasiswa dapat membaca kritis, sehingga pendapat antar mahasiswa berpengaruh pada pembelajaran Dokkai. Kedua cara tersebut, Selain dapat memudahkan mahasiswa dalam mempelajari Dokkai dengan cara menyenangkan, mahasiswa juga dapat mengeksplor diri dalam tim maupun di dalam kelas.

\section{METODE PENELITIAN}

Penelitian ini menggunakan metode penelitian eksperimen. Untuk desain penelitian eksperimen, peneliti menggunakan true experimental design dengan bentuk desain penelitian Pretest-Posttest Control Group Design. Menurut Sugiyono (2013), pada desain ini terdapat dua kelompok yang dipilih secara random (kelompok eksperimen dan kelompok kontrol), kemudian diberi pre-test untuk mengetahui keadaan awal (sebelum penelitian), lalu setelah kelompok eksperimen diberikan perlakuan, kelompok eksperimen dan kelompok kontrol diberi post-test untuk mengetahui perbedaan antara kedua kelompok tersebut. Dengan kata lain, desain penelitian ini melaksanakan observasi sebanyak dua kali (pre-test dan post-test), sehingga hasil penelitian lebih akurat.

Populasi dalam penelitian ini adalah mahasiswa semester 5 Program Studi Pendidikan Bahasa Jepang di salah satu universitas negeri di Jakarta tahun akademik 2018/2019. Peneliti menggunakan teknik penyampelan purposif atau dapat juga disebut sampel bertujuan (purposive sample). Menurut Arikunto (2010) teknik ini dilakukan dengan cara mengambil subjek berdasarkan atas tujuan tertentu. Peneliti memilih teknik ini karena tujuannya adalah meneliti mata kuliah Dokkai III, maka sampel yang diambil adalah mahasiswa semester 5 yang mengambil mata kuliah Dokkai III, Program Studi Pendidikan Bahasa Jepang di salah satu universitas negeri di Jakarta tahun akademik 2018/2019. Peneliti memilih 2 kelas, yaitu kelas A sebagai kelas eksperimen dan kelas B sebagai kelas kontrol.
Instrumen Penelitian menurut Sutedi (2009, p.155) adalah "alat yang digunakan untuk mengumpulkan atau menyediakan berbagai data yang diperlukan dalam kegiatan penelitian." Instrumen yang akan digunakan dalam penelitian ini adalah instrumen tes, angket, dan wawancara bebas.

Kegiatan eksperimen dalam penelitian kali ini ada tiga langkah, yaitu pra-membaca, membaca, dan pasca-membaca. Langkah-langkahnya adalah sebagai berikut:

1. Pra-membaca: (1) Peneliti memberikan soal kosakata "Charenji Shimashou" dan mengarahkan mahasiswa untuk mengerjakan semampunya tanpa melihat kamus; (2) Mahasiswa diperbolehkan untuk bertanya pada teman di sekeliling kelas untuk melengkapi jawaban tanpa melihat kamus; (3) Peneliti meminta mahasiswa untuk kembali ke tempat semula. Lanjut dengan membahas kosakata bersama.

2. Membaca: (1) Mahasiswa diminta mengamati soal yang telah dikerjakan sebelumnya dan menebak tema dokkai hari ini; (2) Membuat kelompok belajar dengan anggota per kelompok sebanyak 2-3 orang; (3) Kelompok memulai diskusi. Sekaligus menuliskan hasil diskusi dan mencari kata kunci di setiap paragraf; (4) Mahasiswa dibebaskan untuk menuliskan kata kunci yang telah didiskusikan di papan tulis; (5) Peneliti membimbing mahasiswa untuk memilih kata kunci yang mewakili dari paragraf tersebut; (6) Mahasiswa mencoba untuk menyimpulkan paragraf melalui kosakata yang telah dituliskan di papan tulis. Mahasiswa bebas membuat kalimat dengan kata-kata sendiri; (7) Hasil kesimpulan dari beberapa kelompok dituliskan di papan tulis. Mahasiswa diminta untuk membacanya, lalu diperbolehkan untuk merevisi atau menyempurnakan kesimpulan yang telah dituliskan; (8) Peneliti memberikan penguatan terhadap kesimpulan yang sudah baik.

3. Pasca-membaca: (1) Mahasiswa diminta untuk membacakan kesimpulan dari awal sampai akhir; (2) Mahasiswa diminta untuk mengutarakan kesimpulan secara keseluruhan dengan versi sendiri secara bergantian.

\section{HASIL DAN PEMBAHASAN}

Sebelum dimulainya penelitian pada proses pembelajaran, peneliti melaksanakan pretest pada kelas eksperimen dan kelas eksperimen. Hasil nilai pretest tersaji dalam Tabel 1 sebagai berikut: 
Tabel 1: Hasil nilai pretest.

\begin{tabular}{|l|r|l|c|}
\hline \multicolumn{4}{|c|}{ NILAI PRETEST } \\
\hline Kelas Eksperimen & \multicolumn{2}{c|}{ Kelas Kontrol } \\
\hline Mean & 55,80 & Mean & 62,89 \\
\hline Min & 40 & Min & 44 \\
\hline Max & 72 & Max & 84 \\
\hline
\end{tabular}

Dari Tabel 1, dapat diketahui bahwa nilai ratarata kelas eksperimen lebih rendah dibandingkan dengan kelas kontrol. Setelah melaksanakan pretest, peneliti memulai proses pembelajaran.

Kelas eksperimen diberikan perlakuan dan kelas kontrol menggunakan metode ekspositori. Setelah empat kali pertemuan, kelas eksperimen dan kelas kontrol melaksanakan posttest supaya ditemukan apakah ada peningkatan atau tidak pada kelas eksperimen dan untuk mengetahui apakah strategi dan pendekatan yang digunakan di kelas eksperimen lebih efektif dibanding kelas kontrol. Hasilnya dapat dilihat dalam Tabel 2.

Tabel 2: Hasil nilai pretest.

\begin{tabular}{|l|l|l|l|}
\hline \multicolumn{4}{|c|}{ NILAI POSTTEST } \\
\hline \multicolumn{2}{|c|}{ Kelas Eksperimen } & \multicolumn{2}{c|}{ Kelas Kontrol } \\
\hline Mean & 79,80 & Mean & 71,11 \\
\hline Min & 52 & Min & 52 \\
\hline Max & 96 & Max & 84 \\
\hline
\end{tabular}

Berdasarkan Tabel 2, dapat disimpulkan bahwa rata-rata kelas eksperimen lebih tinggi daripada ratarata kelas kontrol. Dari nilai rata-rata tersebut dapat terlihat bahwa kemampuan mahasiswa kelas eksperimen meningkat dibandingkan dengan hasil pretest.

Selanjutnya, sebelum melakukan uji hipotesis, terlebih dahulu melakukan uji prasyarat, yaitu uji normalitas dan uji homogenitas. Setelah itu melakukan uji efektifitas. Hasil uji normalitas adalah seperti pada Tabel 3 .

Tabel 3: Hasil uji normalitas.

\begin{tabular}{|l|l|c|}
\hline \multicolumn{3}{|c|}{ One-Sample Kolmogorov-Smirnov Test } \\
\hline \multicolumn{2}{|c|}{} & Nilai Pretest \\
\hline \multirow{2}{*}{$\mathrm{N}$} & Mean & 38 \\
\hline \multirow{2}{*}{$\begin{array}{l}\text { Normal } \\
\text { Parameters }{ }^{\mathrm{a}, \mathrm{b}}\end{array}$} & Std. Deviation & 59,1579 \\
\hline \multirow{2}{*}{$\begin{array}{l}\text { Most Extreme } \\
\text { Differences }\end{array}$} & Absolute & 11,12709 \\
\cline { 2 - 3 } & Positive & 0,131 \\
\cline { 2 - 3 } & Negative & $-0,131$ \\
\hline \multicolumn{2}{|l|}{ Kolmogorov-Smirnov Z } & 0,811 \\
\hline \multicolumn{2}{|l|}{ Asymp. Sig. (2-tailed) } & 0,527 \\
\hline \multicolumn{2}{|l|}{ a. Test distribution is Normal. } \\
\hline \multicolumn{2}{|l|}{ b. Calculated from data. } \\
\hline
\end{tabular}

Uji normalitas digunakan untuk mengetahui apakah data sudah terdistribusi dengan normal atau tidak. Uji normalitas dilakukan terhadap nilai pretest. Hasilnya adalah sebagai berikut.Hasil yang diperoleh adalah 0,527 >0,05, maka dapat ditarik kesimpulan bahwa data kelas eksperimen dan kelas kontrol berdistribusi normal.

Uji prasyarat selanjutnya adalah uji homogenitas. Uji homogenitas digunakan untuk menguji apakah rata-rata antara kelas eksperimen dan kelas kontrol yang independen memiliki varian yang sama atau tidak. Hasilnya tersaji dalam Tabel 4 berikut.

Tabel 4: Hasil uji homogenitas.

\begin{tabular}{|c|c|c|c|}
\hline \multicolumn{4}{|c|}{ Test of Homogeneity of Variances } \\
\hline Nilai_Pretest \\
\hline Levene Statistic & df1 & df2 & Sig. \\
\hline 0,422 & 1 & 36 & 0,520 \\
\hline
\end{tabular}

Karena 0,520 > 0,05 maka $\mathrm{H}_{0}$ diterima. Jadi, dapat disimpulkan bahwa nilai pretest kelas eksperimen dan kelas kontrol memiliki varian yang sama sebelum diberi perlakuan atau dapat disebut homogen. Karena data sudah homogen, maka langkah selanjutnya adalah uji hipotesis.

Uji efektivitas adalah menguji hipotesis dengan Independent Samples T-Test yang digunakan untuk mengetahui ada tidaknya perbedaan rata-rata antara dua kelompok sampel yang tidak berhubungan atau bebas (independent). Hasil uji efektivitas dapat dilihat dalam Tabel 5.

Tabel 5: Hasil uji efektivitas.

\begin{tabular}{|c|c|c|c|c|c|c|c|}
\hline & & Inde & ependen & Sampl & es Test & & \\
\hline & & t-te & st for $\mathrm{Eq}$ & uality o & Means & & \\
\hline & & $\mathrm{T}$ & 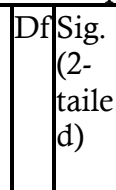 & $\begin{array}{l}\text { Mean } \\
\text { Diffe- } \\
\text { rence }\end{array}$ & \begin{tabular}{|l} 
Std. \\
Error \\
Diffe- \\
rence
\end{tabular} & $\begin{array}{l}95 \% \\
\text { Confic } \\
\text { Interv } \\
\text { the } \\
\text { Differ }\end{array}$ & $\begin{array}{l}\text { dence } \\
\text { al of } \\
\text { ence }\end{array}$ \\
\hline & & & & & & Lower & $\begin{array}{l}U p- \\
\text { per }\end{array}$ \\
\hline $\begin{array}{l}\text { Nilai } \\
\text { Post- } \\
\text { test }\end{array}$ & \begin{tabular}{|l|} 
Equal \\
varian- \\
ces \\
assumed
\end{tabular} & $\begin{array}{l}2, \\
547\end{array}$ & $36\left[\begin{array}{l}0, \\
015\end{array}\right.$ & 8,689 & 3,411 & 1,770 & $\begin{array}{l}15, \\
608\end{array}$ \\
\hline
\end{tabular}

Dari tabel 5, diperoleh thitung sebesar 2,547 dan $d f$ yang didapatkan sebesar 36 , jadi tabel yang diperoleh adalah 2,028. Dengan demikian 2,547 > 2,028 yang berarti thitung lebih besar daripada $\mathrm{t}_{\text {tabel, }}$ maka $\mathrm{H}_{0}$ ditolak. Dapat disimpulkan bahwa terdapat efektivitas strategi Active Knowledge Sharing dalam pembelajaran Dokkai dengan pendekatan saintifik pada mahasiswa.

Lalu, peneliti menyebarkan angket dan wawancara bebas dengan tujuan untuk mengetahui 
kelebihan dan kekurangan dari strategi ini. Kelebihannya adalah sebagai berikut: (1) Membuat mahasiswa lebih mudah dan cepat dalam memahami isi bacaan; (2) Mahasiswa saling membantu dalam menyelesaikan suatu masalah sehingga dapat mengatasi kesulitan-kesulitan dalam mempelajari dokkai; (3) Dapat meningkatkan daya ingat pada memori jangka panjang sehingga dapat menguatkan pemahaman teks bacaan yang telah dipelajari dalam jangka waktu yang lama. Dan kekurangannya adalah: (1) Kurang cocok dengan karakter mahasiswa yang lebih suka belajar sendiri; (2) Kurang cocok bagi mahasiswa yang tidak suka berpindah tempat duduk; (3) merasa terbebani jika mengerjakan soal di awal (seperti pretest).

Jadi, dapat dipahami bahwa strategi Active Knowledge Sharing dengan pendekatan saintifik sudah dapat mengatasi masalah mahasiswa dalam memahami bacaan berbahasa Jepang. Dengan kerjasama antar teman satu tim dan kerjasama dari seluruh kelompok, maka seluruh siswa di kelas dapat mencapai tujuan bersama dalam memahami dokkai. Soal kosakata yang diberikan di awal pembelajaran dapat membantu mahasiswa mengenal kosakata yang akan dipelajari sebelum masuk ke bahan bacaan. Soal kosakata tersebut dilengkapi dengan cara baca kanji, sehingga mempermudah mahasiswa dalam membaca sambil melihat huruf kanji. Setelah mengerjakan soal tersebut sendiri, akan diberikan waktu untuk saling berbagi pengetahuan dengan berkeliling kelas. Gerakan ini dapat membuat siswa bersemangat dibandingkan dengan duduk terus menerus.

\section{SIMPULAN}

Berdasarkan hasil analisis data di atas, dapat disimpulkan bahwa strategi Active Knowledge Sharing dengan pendekatan saintifik memiliki efektifitas dalam pembelajaran Dokkai tingkat menengah. Jika dibandingkan dengan pendekatan ekspositori, cara ini cukup baik diterapkan di dalam kelas. Dalam penelitian ini juga ditemukan kelebihan dan kekurangan. Beberapa kelebihan yang ditemui sebagian besar sama seperti yang ada pada teori, yaitu strategi ini dapat membuat mahasiswa lebih aktif dalam belajar, berani untuk mencoba mengemukakan pendapat di depan kelas, aktif dalam bekerja sama dan bersosialisi dengan melakukan tanya-jawab. Hal baru yang ditemukan dalam penelitian ini adalah mahasiswa tidak bergantung pada kamus elektronik, dapat memprediksi bacaan dengan baik walaupun belum mempelajari tata bahasanya, dan dapat menyimpulkan suatu paragraf maupun bacaan dengan kalimat yang disusun sendiri tanpa mengikuti struktur kalimat yang ada di teks. Namun, kekurangan yang ditemukan dari strategi ini dalam pembelajaran Dokkai III (Dokkai tingkat menengah) adalah alangkah baiknya jika jalannya pembelajaran lebih ditekankan kepada membaca kritis, tidak hanya pemahaman kanji dan kosakata saja. Soal sebelum mulai pembelajaran, lebih baik ditambahkan pertanyaan $5 \mathrm{~W}+1 \mathrm{H}$, supaya dapat melatih mahasiswa untuk berpikir kritis sesuai dengan tema bacaan yang akan dipelajari.

Karena Strategi Active Knowledge Sharing dengan pendekatan saintifik dinilai efektif digunakan untuk pembelajaran dokkai semester lima, maka dapat diimplikasikan ke pembelajaran bahasa Jepang, khususnya untuk mata kuliah dokkai (tingkat menengah) maupun mata kuliah yang terdapat dokkai di dalamnya. Strategi Active Knowledge Sharing dengan pendekatan saintifik dapat menjadi salah satu alternatif pengajaran dokkai, supaya langkah-langkah pembelajaran lebih variatif dan memudahkan mahasiswa dalam memahami bacaan berbahasa Jepang. Strategi ini pun dapat divariasikan dengan metode lain (fleksibel). Selain itu, mahasiswa diberi kesempatan untuk aktif dan ikut berperan dalam pembelajaran. Dapat melatih mahasiswa dalam menyampaikan ide-ide, pendapat, berani untuk mencoba (karena dapat ikut berperan dalam pembelajaran).

\section{DAFTAR PUSTAKA}

Arikunto, S. (2010). Prosedur Penelitian Suatu Pendekatan Praktik. Jakarta: Rineka Cipta.

Arini, A. (2012). Efektivitas Strategi Active Learning Model Active Knowledge Sharing pada Pembelajaran Jitsuyou Choukai I. (Skripsi, Universitas Penddikan Indonesia). Diakses http://repository.upi.edu/id/eprint/10835

Zen, F. M. (2014). Efektifitas Strategi Pembelajaran Active Knowledge Sharing dalam Peningkatan Kemampuan Kosakata. (Skripsi, Universitas Pendidikan Indonesia). Diakses http://repository.upi.edu/id/eprint/11258

Hosnan, M. (2014). Pendekatan Saintifik dan Kontekstual dalam Pembelajaran Abad 21. Bogor: Ghalia Indonesia.

Mizutani, O. 2005. Shinpan Nihongo Kyouiku Jiten (Kamus Pendidikan Bahasa Jepang Edisi Revisi). Tokyo: Taishuukan Shoten.

Rusman, R. (2014). Model-Model Pembelajaran: Mengembangkan Profesionalisme Guru. Jakarta: PT Raja Grafindo Persada.

Sagala, S. (2010). Konsep dan Makna Pembelajaran. Bandung: Alfabeta.

Silberman, M. L. (2013). Active Learning 101: Cara Belajar Siswa Aktif. (R. Muttaqien, Trans.). Bandung: Nusa Cendikia. 
Soedarso, S. (1994). Sistem Membaca Cepat dan Efektif. Jakarta: Gramedia Pustaka Utama.

Sugiyono, S. (2010). Metode Penelitian Kuantitatif, Kualitatif, dan $R \& D$. Bandung: Alfabeta.

Sugiyono, S. (2013). Metode Penelitian Kombinasi (Mixed Method). Bandung: Alfabeta.
Sutedi, D. (2009). Penelitian Pendidikan Bahasa Jepang. Bandung: Humaniora Utama Press.

Uno, H. B. (2008). Model Pembelajaran: Menciptakan Proses Belajar Mengajar yang Kreatif dan Efektif. Jakarta: Bumi Aksara. 


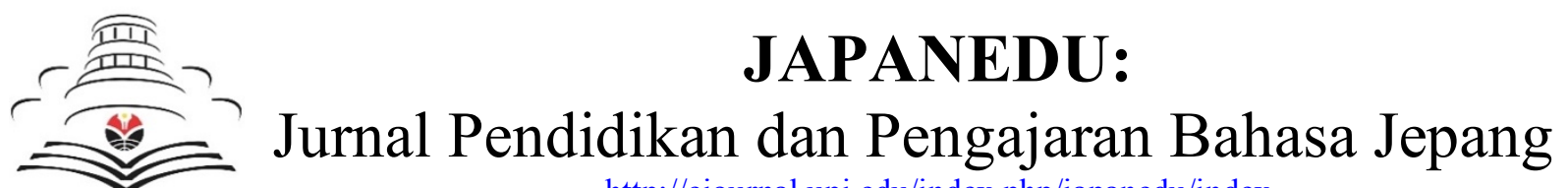

\title{
Embbed Dajare Word Play Process in "Shirokuma Cafe"”
}

\author{
Talin Salisah*, Nani Sunarni \\ Linguistic Program, Faculty of Humanities, Universitas Padjadjaran, Bandung, Indonesia \\ talinsalisah@gmail.com*
}

\begin{abstract}
Pun, in English, is a word play that is very suitable for Japanese, which has many homonyms. The name of word play in Japanese is called dajare. Many experts mention the types of dajare, and one of the researchers mentioned that there are three types of dajare. These three of types are homophonic dajare, near-homophonic dajare, and embbed dajare. One of the three types of dajare is the main focus of research. This research explained the analysis of embbed dajare in an animated show titled "“Shirokuma Café"”, the show that has a lot of dajare in conversations between Shirokuma and his friends which is seen from the vocabularies are used. The purpose of this research was to study how the embbed dajare word play process is used in the conversation between Shirokuma and the person he is talking to. The research method used is a descriptive qualitative method. The results of this research showed that the same or similarity of sound and form of dajare does not guarantee the similarity of meaning between the referent word and the target word.

$$
\text { K E Y W O R D }
$$
\end{abstract}

Dajare; Embbed; Pun; Shirokuma Cafe

First received: 7 February 2020

Available online: 20 June 2010

Final proof accepted: 15 May 2020

\section{PENDAHULUAN}

Bahasa menjadi sebuah media dalam membantu proses komunikasi antar individu. Di dalam bahasa, fungsi-fungsi penting hadir agar penyampaian serta penerimaan informasi dapat berjalan dengan lancar. Kenneavy (dalam Chaer \& Agustina, 2014) mengungkapkan bahwa bahasa memiliki lima fungsi, yaitu ekspresi (expression), informasi (information), eksplorasi (exploration), ajakan (persuasion), dan hiburan (entertainment). Namun, ketika proses komunikasi lisan yang terjadi, bunyi yang serupa kadangkala terdengar dari pembicara. Menurut Otake (2010), hal tersebut merupakan sebuah kejadian yang tidak bisa dihindari karena bahasa lisan terbentuk dari bunyi-bunyi yang terbatas sehingga bentuk komunikasi secara lisan menggunakan kata-kata yang bunyinya serupa. Fenomena tersebut kemudian dimanfaatkan menjadi sesuatu yang menarik bahkan mengundang tawa yang disampaikan melalui humor sebagai alternatif lain dalam memberikan suatu pesan. Menurut Berger (2011), teknik-teknik humor yang diaplikasikan ke dalam suatu karya seperti buku, permainan, komik, dan hal lainnya digunakan untuk menciptakan situasi yang lucu serta menghibur orang-orang. Berger (2011) pun menjelaskan 
empat kategori dasar yang ada di dalam humor. Keempat kategori tersebut adalah sebagai berikut.

a. Humor melibatkan identitas;

b. Humor melibatkan bahasa;

c. Humor melibatkan logika;

d. Humor melibatkan aksi atau fenomena secara visual.

Jika melihat kategori-kategori di atas, humor memiliki kaitan yang erat dengan bahasa serta identitas, di mana humor tidak jauh dari percakapan atau pertukaran informasi antar individu. Humor memiliki ciri khas masingmasing dari setiap bahasa yang ada di dunia.

Humor memiliki bagian-bagian, salah satunya adalah jokes dan jokes sendiri memiliki beberapa jenis yang di dalamnya terdapat permainan kata. Dalam bahasa Inggris, permainan kata disebut dengan istilah "pun" atau paronomasia.

Di dalam aplikasi Kamus Besar Bahasa Indonesia edisi lima, paronomasia adalah permainan kata yang memanfaatkan polisemi atau homonimi. Lalu, Kamus Oxford daring menjelaskan bahwa paronomasia diartikan sebagai "a play on a words; a pun". Apabila dihubungkan dengan definisi pada Kamus Oxford daring, Cambridge Advanced Learner's Dictionary (dalam Dybala, Rzepka, \& Sayama, 2012) mendefinisikan istilah pun sebagai permainan kata yang merupakan penggunaan kata-kata menarik yang memiliki beberapa makna atau terdengar seperi kata-kata yang lain. Dari definisi tersebut, pun dapat diartikan sebagai permainan yang memanfaatkan kata-kata yang memiliki bunyi yang sama/mirip, namun makna antar kata memiliki memiliki perbedaan tersendiri.

Menurut Leppihalme (dalam Giorgadze, 2014) permainan kata memiliki beberapa bentuk dasar yang berbeda-beda. Bentuk-bentuk tersebut adalah cara pengucapan, ejaan, morfologi, kosakata, dan sintaksisnya. Pun memiliki klasifikasi tersendiri. Salah satu ahli, Delabastita (dalam Giorgadze, 2014) menyatakan bahwa pun memiliki empat kategori, yaitu homonim (ejaan dan bunyi yang mirip), homofon (bunyinya mirip, tetapi ejaannya berbeda), homografi (bunyinya berbeda, tetapi ejaannya mirip), dan paronim (ada sedikit perbedaan di dalam bunyi mau pun ejannya). Giorgadze (2014) menyimpulkan dari beberapa pendapat termasuk Delabastita mengenai klasifikasi pun, bahwa pun mempunyai tiga klasifikasi yaitu pun dengan makna leksikal, pun dengan struktur sintaksis, dan pun dengan makna struktural.
Tidak hanya di dalam bahasa Inggris, bahasa Jepang pun tidak luput menggunakan permainan yang berhubungan dengan kata. Shinohara (2009) menyebutkan dua permainan tradisional yang ada di dalam bahasa Jepang, yaitu shiritori dan dajare. Dajare merupakan padanan kata dari “ $d a$ ”(駄) dan "share" (酒落) yang memiliki makna 'buruk' dan 'candaan, pun'.

Di sisi lain, Kamus Super Daijirin (dalam Dybala, Rzepka, \& Sayama, 2012) menyebutkan dajare adalah 'Hetana share. Tsumaranai share'. Apabila diartikan, dajare merupakan share yang buruk atau membosankan. Sedangkan istilah share jika dilihat dalam kamus The Wisdom EnglishJapanese (dalam Dybala, Rzepka, \& Sayama, 2012) merupakan sebuah joke atau pun. Jika disimpulkan, dajare merupakan candaan atau permainan kata yang buruk (hambar).

Melihat pendapat-pendapat mengenai dajare dan pun yang sudah disebutkan sebelumnya, permainan tersebut mengandalkan kata-kata yang memiliki sifat homonim atau homofon. Untuk mengaplikasikannya ke dalam percakapan maupun pembelajaran, seorang individu membutuhkan jumlah kosakata yang memadai. Jika permainan kata seperti dajare dapat dikuasai oleh seseorang, maka kesempatan pembendaharaan kata yang dimiliki akan bertambah serta bervariasi. Viera (2017) menyatakan pengetahuan mengenai kosakata dilihat sebagai alat yang esensial untuk menguasai kemampuan bahasa apapun. Ia menyebutkan pula bahwa kosakata adalah aspek yang berkontribusi dalam memahami teks tertulis atau percakapan. Kesulitan-kesulitan dalam mengumpulkan berbagai kosakata dapat diminimalisir dengan berbagai alternatif pula, salah satunya adalah dajare yang diperuntukkan bagi pembelajar bahasa Jepang.

\section{KLASIFIKASI $D A J A R E$}

Keberadaan pun atau dajare dalam bahasa Jepang yang menjadi bagian dari proses berbahasa, menggerakkan para peneliti melakukan suatu penelitian yang memiliki kaitannya dengan dajare. Dimulai dari bunyi, pembentukan, serta hal lainnya. Seorang peneliti bernama Otake (2010) melakukan penelitian tentang permainan kata bahasa Jepang, dajare. Di dalam penelitian tersebut, dajare terbagi menjadi tiga jenis, yaitu homophonic dajare, near-homophonic dajare, dan 
embbed dajare. Berikut ini penjelasan tentang tiga klasifikasi dajare.

\section{A. Homophonic Dajare}

Posisi homophonic dajare setara dengan dengan pun yang berhomofonik. Di sana tidak ada manipulasi secara fonologi dan memiliki bunyi yang identik. Contoh kalimat yang ber-homophonic dajare adalah sebagai berikut.

$[$ Koosoku $] \quad n i \quad[$ koosoku $] \quad$ sareru
'peraturan sekolah'
'Diikat oleh peraturan sekolah'

Kalimat tersebut memiliki dua kata yang memiliki bunyi yang sama (douongo), akan tetapi memiliki makna yang berbeda, di mana kata koosoku yang pertama (menunjukkan referensi) adalah peraturan sekolah. Lalu, koosoku yang kedua (menunjukkan kata target) memiliki makna mematuhi. Makna "dipatuhi" dalam kalimat di atas dikarenakan adanya imbuhan (setsuji) yang menujukkan kata pasif (ukemi).

\section{B. Near-homophonic Dajare}

Hampir mirip dengan homophonic dajare, nearhomophonic dajare memiliki bentuk yang sedikit lebih rumit. Pada klasifikasi ini, dajare dibagi lagi menjadi dua bagian, yaitu, segmental manipulation dan durational manipulation.

\section{a. Segmental manipulation}

Dalam klasifikasi ini, terdapat manipulasimanipulasi bunyi, seperti manipulasi konsonantal dan manipulasi vokal. Contoh kalimat-kalimat segmental manipulation adalah sebagai berikut.

a) Daisu[ke] daisu[ki].

'Daisuke' suka'

'(aku) suka Daisuke.'

b) [Ha]shimoto, [a]shimoto ga abunai!

'Hashimoto' 'langkah' 'berbahaya'

'Hashimoto, hati-hati dengan langkahmu!'

b. Durational manipulation

Untuk klasifikasi ini, manipulasi panjang atau pendeknya bunyi terjadi. Contoh kalimat-kalimat durational manipulation adalah sebagai berikut.

a) Haiteku no sekaini haitteku.

'Teknologi 'dunia' 'masuk'

tinggi'

'Masuk ke dalam dunia teknologi modern.' b) [Herushii] ni taijuu ga [herushi]. 'sehat' 'berat badan' 'turun'

'Menurunkan berat badan dengan sehat.'

\section{Embbed Dajare}

Klasifikasi ini memiliki ciri berbeda dengan dua klasifikasi sebelumnya. Embbed dajare mempunyai sistem dasar yang sama dengan pun. Contoh kalimat-kalimat embbed dajare adalah sebagai berikut.

$\begin{array}{lll}\text { a) [Sake] } & g a \quad \text { [sake]nda. } \\ \text { 'ikan salmon' } & \text { 'teriak' }\end{array}$

'Ikan salmon berteriak.'

b) A[komu] wa [komu]. 'perusahaan Acom' 'penuh'

'Di dalam perusahaan Acom penuh'.

c) [Baiku] wa gasorin o [bai] [ku]u. 'motor' 'gas' 'dua kali' 'memakan' 'Motor (ini) mengonsumsi dua kali lipat sama seperti gas.'

Dilihat dari ketiga klasifikasi di atas, maka perubahan makna dan pembentukan kata pun muncul ke permukaan walaupun di antara katakata di atas memiliki bunyi yang sama atau yang serupa. Di sisi lain, semantik menurut Leech (2003) adalah tentang makna, di mana adanya pemikiran sistematik tentang dasar makna. Lalu, Bloomfield (dalam Leech, 2003) menyatakan bahwa untuk mendefinisikan makna, maka lihat hubungan makna tersebut dengan benda bersangkutan dan kita memiliki pengetahuan tentang benda itu. Di dalam proses pembentukan kata pun, perubahan bunyi dapat terjadi. Fenomenta tersebut bernama hen'on genshou. Human Academy (2014) menyatakan ketika pembentukan kata sedang diproses, terjadi sebuah perubahan bunyi. Ada delapan perubahan bunyi menurut buku tersebut. Tabel 1 berikut menunjukkan perubahan-perubahan bunyi yang terjadi pada saat pembentukan kata. 
Tabel 1: Gejala perubahan bunyi (Hen'on genshou).

\begin{tabular}{|c|c|c|}
\hline $\begin{array}{l}\text { Hen'on } \\
\text { Genshou }\end{array}$ & Penjelasan & Contoh \\
\hline Rendaku & $\begin{array}{l}\text { Perubahan bunyi } \\
\text { menjadi bunyi } \\
\text { yang bersuara }\end{array}$ & $\begin{array}{l}\text { Hon }+\underline{\tan } a= \\
\text { Hon } \underline{\operatorname{dan} a}\end{array}$ \\
\hline $\begin{array}{l}\text { Ten'on } \\
\text { (Bouin } \\
\text { koutai) }\end{array}$ & $\begin{array}{l}\text { Perubahan bunyi } \\
\text { vokal }\end{array}$ & $\begin{array}{l}\text { Sake }+y a \\
=\text { Sa } \underline{k a y a}\end{array}$ \\
\hline Onbin & $\begin{array}{l}\text { Perubahan bunyi } \\
\text { menjadi bunyi [i], } \\
{[\mathrm{u}], \text { sokuon }} \\
\text { (ッ), hatsuon }[\mathrm{n}]\end{array}$ & $\begin{array}{l}\text { Buchinaguru } \\
\rightarrow \text { Bunnaguru }\end{array}$ \\
\hline On'in tenka & $\begin{array}{l}\text { Fenomena di mana } \\
\text { bunyi yang tidak } \\
\text { ada di elemen asli } \\
\text { ditambahkan ke } \\
\text { dalam kata-kata } \\
\text { yang dibentuk }\end{array}$ & $\begin{array}{l}\text { Haru + ame } \\
=\text { Harusame }\end{array}$ \\
\hline $\begin{array}{l}\text { On'in } \\
\text { datsuraku }\end{array}$ & $\begin{array}{l}\text { Fenomena di mana } \\
\text { bunyi yang ada di } \\
\text { elemen asli dalam } \\
\text { kata yang dibentuk } \\
\text { dihilangkan }\end{array}$ & $\begin{array}{l}\text { Ara }+ \text { iso } \\
=\text { Ariso }\end{array}$ \\
\hline $\begin{array}{l}\text { On'in } \\
\text { yungou }\end{array}$ & $\begin{array}{l}\text { Fenomena di mana } \\
\text { bunyi di akhir } \\
\text { elemen kata } \\
\text { pertama dan bunyi } \\
\text { awal pada kata } \\
\text { kedua bergabung }\end{array}$ & $\begin{array}{l}\text { Kari }+\underline{u} d o \\
=\overline{\text { Karyuud }}\end{array}$ \\
\hline Ren'on & $\begin{array}{l}\text { Fenomena yang } \\
\text { terjadi di mana } \\
\text { bunyi }[\mathrm{n}],[\mathrm{m}],[\mathrm{t}] \\
\text { pada bunyi akhir } \\
\text { kata pertama } \\
\text { mempengaruhi } \\
\text { deret bunyi [a], } \\
\text { [ya], [wa] yang } \\
\text { berada di awal kata } \\
\text { kedua, } \\
\text { menghasilkan } \\
\text { bunyi deret [ta], } \\
\text { [na], [ma] }\end{array}$ & $\begin{array}{l}\text { In }+e n \\
=\text { Innen }\end{array}$ \\
\hline $\begin{array}{l}\text { Handakuon } \\
\mathrm{ka}\end{array}$ & $\begin{array}{l}\text { Fenomena di mana } \\
\text { bunyi [ha] berubah } \\
\text { menjadi [pa] }\end{array}$ & $\begin{array}{l}\text { Ake + hiroge } \\
=\text { Ageppiroge }\end{array}$ \\
\hline
\end{tabular}

Fadilah (2017) meneliti pembentukan dan makna kontekstual dajare dengan sumber data serial kartun Doraemon. Penelitian tersebut menyimpulkan bahwa terdapat tujuh dari dua belas klasifikasi dajare yang dinyatakan oleh Dybala, Rzepka, dan Sayama (2012). Dajare tersebut antara lain muncul dengan beberapa pembentukan kata seperti derivasi, afiks, compounding, clipping, reduplikasi, dan borrowing. Tujuh klasifikasi tersebut yaitu, homophony, mora addition (initial, internal, final), mora omission (initial), mora transformation (vowel), kanji readings change, mix of languanges, dan pause transference. Setelah itu terdapat makna yang menunjukkan kata benda, kata kerja, kata keterangan, dan beberapa ungkapan. Namun penelitian tersebut menitikberatkan kepada pola kalimat lengkap, sedangkan penelitian ini memfokuskan pada kata dasar yang menghasilkan beberapa kosakata lain yang memiliki bunyi yang sama atau serupa berdasarkan proses hen'on genshou.

Namun demikian, dalam penelitian ini ruang lingkup analisis hanya berada pada klasifikasi embbed dajare saja. Penelitian ini bertujuan untuk melihat proses permainan klasifikasi embbed dajare pada animasi " "Shirokuma Café"” dengan melihat hubungan antara bunyi serta makna kata referen dan kata target.

\section{METODE PENELITIAN}

Sumber data diambil dari animasi Jepang " "Shirokuma Café"” yang tayang pada tahun 2012-2013, dengan keseluruhan jumlah penayangan yaitu 50 (lima puluh) episode dengan durasi per episode sepanjang 24 (dua puluh empat) menit. "Shirokuma Café" diadaptasi dari komik dengan judul sama yang ditulis oleh Aloha Higa. "Shirokuma Café" menceritakan kehidupan sehari-hari para binatang yang bertindak serta berbicara layaknya manusia dan melakukan interaksi pula dengan manusia di sekitarnya. Namun, latar tempat yang sering diperlihatkan di dalam cerita merupakan sebuah kafe yang dimiliki oleh beruang kutub bernama Shirokuma. Di dalam animasi tersebut terdapat proses permainan dajare yang dilakukan Shirokuma dengan lawan bicaranya.

Proses pengumpulan data dilakukan melalui metode simak (Mahsun, 2017). Selanjutnya, proses mencatat kalimat atau kosakata yang berhubungan dengan dajare dilakukan. Setelah data didapatkan, proses analisis diawali oleh tahap pengklasifikasian berdasarkan teori menurut pandangan Otake (2010) mengenai tiga jenis dajare dan mengambil data klasifikasi embbed dajare sebagai bahan analisis. Setelah pengklasifikasian data, analisis difokuskan terhadap perubahan pembentukan dari kata pada setiap kelompok dengan melihat perubahan bunyi. Kemudian, menganalisis perubahan makna dari kata referen dan kata target, lalu membandingkan apakah 
makna-makna yang ada saling berhubungan. Lalu, menyimpulkan hasil analisis.

\section{HASIL DAN PEMBAHASAN}

"Shirokuma Café" memiliki total 50 (lima puluh) episode dengan percakapan-percakapan antar tokoh yang dihiasi permainan kata (dajare). Fenomena dajare yang muncul pada tayangan tersebut dilakukan oleh tokoh bernama Shirokuma. Shirokuma sering terpancing oleh satu kata spesifik yang dilontarkan oleh lawan bicara, lalu memeragakan setiap kata yang bunyinya mirip dengan kata sebelumnya (kata referen). Akibatnya, lawan bicara Shirokuma harus menyebutkan katakata yang diperagakan. Dajare yang diucapkan rata-rata berada di hampir di setiap episode serta di satu episode tersebut memiliki dua atau tiga kelompok permainan kata, bahkan jumlahnya dapat lebih dari biasanya. Shirokuma adalah tokoh yang menyukai dajare dan akan merasa kesepian ketika tidak ada yang merespon perilakunya tersebut.

Data-data yang didapatkan dari tayangan tersebut hanya menunjukkan topik yang sedang diperagakan atau yang dibicarakan saat itu. Datadata yang ditemukan berupa satu kelompok yang terdiri dari satu kata referensi utama dan satu hingga beberapa kata target. Namun, pola kata dajare pada tayangan ini tidak selalu bertumpu pada kata referensi utama yang disebutkan di awal. Pola permainan kata dapat diambil dari salah satu kata target, dan menjadikan kata tersebut sebagai kata referensi. Sehingga kata-kata lain keluar dengan bunyi yang serupa dari kata bersangkutan. Di bawah ini merupakan kelompok-kelompok yang masuk ke dalam klasifikasi embbed dajare, seperti yang tersaji dalam Tabel 2 .
Tabel 2: Percakapan yang mengandung embbed dajare.

\begin{tabular}{|c|c|}
\hline Episode & Kalimat percakapan \\
\hline \multirow{9}{*}{$\begin{array}{l}\text { Tujuh } \\
\text { belas }\end{array}$} & Panda: $A a$, nimotsu ooi ne. \\
\hline & 'Oh, banyak sekali barang bawaannya' \\
\hline & Penguin: Kyanpu dakara ne. \\
\hline & 'Karena kita akan berkemah.' \\
\hline & Panda: Kyanpu? \\
\hline & 'Berkemah?’ \\
\hline & Shirokuma: $e$ ? \\
\hline & 'Apa?' \\
\hline & $\begin{array}{l}\text { Penguin: Sore wa chanpu, sore wa suranpu, } \\
\text { sore wa bagupaipu, sore wa gooyachanpuru. } \\
\text { "Itu "menang", itu "kemerosotan", itu } \\
\text { "bagpipe", itu "gooyachanpuru*", }\end{array}$ \\
\hline \multirow{9}{*}{ Empat } & $\begin{array}{l}\text { Penguin: Shashin totte ii kana? } \\
\text { 'Apa boleh dipotret?' }\end{array}$ \\
\hline & $\begin{array}{l}\text { Panda: Shashin? Kamera motterunda. } \\
\text { 'Memotret? Oh, bawa kamera, ya' }\end{array}$ \\
\hline & $\begin{array}{l}\text { Penguin: Kamera tte iu ka sa. Kattanda, } \\
\text { sumafo. } \\
\text { 'Bukan kamera sih. Aku sudah beli } \\
\text { ponsel pintar' }\end{array}$ \\
\hline & Panda: Nani, sumafo tte? \\
\hline & 'Apa itu ponsel pintar?' \\
\hline & Shirokuma: (terpancing) \\
\hline & (Sambil melihat Shirokuma \\
\hline & $\begin{array}{l}\text { Penguin: Sore wa sumaki, sore wa chimaki, } \\
\text { hachimaki, hamaki, hamachi, kimuchi! }\end{array}$ \\
\hline & $\begin{array}{l}\text { "Itu "dibungkus tikar", itu "pembungkus } \\
\text { kue beras", itu "pengikat kepala", itu } \\
\text { "cerutu", itu "ikan Hamachi", itu } \\
\text { "kimchi"!' }\end{array}$ \\
\hline \multirow{11}{*}{ Empat } & (Melihat ban mobil kempes) \\
\hline & Panda: Kore tte.... \\
\hline & \\
\hline & $\begin{array}{l}\text { Penguin: Are da ne. (menunjukkan kata } \\
\text { panku) }\end{array}$ \\
\hline & 'Iya, memang itu' \\
\hline & $\begin{array}{l}\text { (sambil melihat Shirokuma } \\
\text { memperagakan diri) }\end{array}$ \\
\hline & Penguin: Sore wa danku. \\
\hline & 'Itu "dunk"' \\
\hline & $\begin{array}{l}\text { Panda: Sore wa inku. } \\
\text { "itu "tinta"" }\end{array}$ \\
\hline & $\begin{array}{l}\text { Penguin: Sore wa pinku. } \\
\text { "itu "warna merah muda", }\end{array}$ \\
\hline & $\begin{array}{l}\text { Panda: Sore wa sukanku. } \\
\text { "itu "musang"" }\end{array}$ \\
\hline
\end{tabular}


Gambar 1 berikut ini merupakan contoh pertama dari klasifikasi embbed dajare.

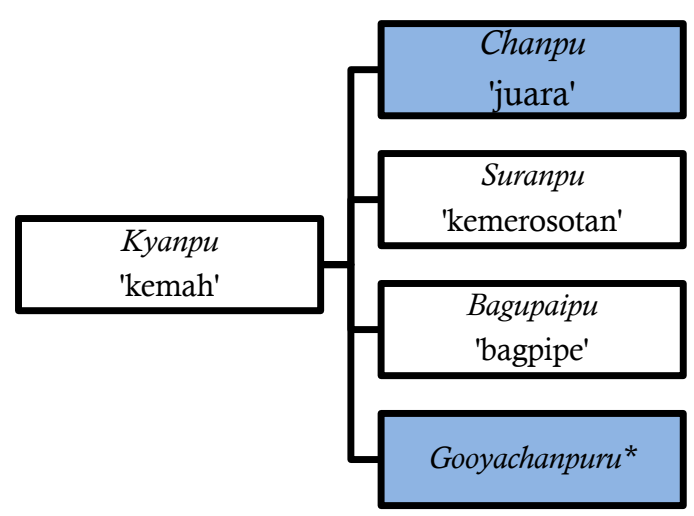

Gambar 1: Proses perubahan bunyi (hen'on) dajare pada episode tujuh belas.

Keempat kata dalam Gambar 1 memiliki bunyi-bunyi yang sama dan serupa. Kata referensi dari empat kata tersebut adalah kata kyanpu, berasal dari istilah bahasa Inggris, camp, yang bermakna berkemah. Proses pembentukan kata tersebut termasuk ke dalam gairaigo, di mana suatu istilah diambil atau diadaptasi dari kata bahasa lain.

Ciri khas dari kelompok kata ini terlihat dari persamaan bunyi mora [pu]. Kemudian, ciri khas lainnya yaitu kecenderungan bunyi konsonan hatsuon $[n]$ menghadapi mora pu pada kata chanpu, suranpu, gooyachanpuru dari kata referen kyanpu yang menghasilkan bunyi bilabial [m]. Walaupun keempat kata memiliki bunyi yang sama dengan kata referen, makna dari masing-masing katanya berbeda.

Kata referen kyanpu dapat berubah menjadi kata chanpu karena keduanya memiliki bunyi yang sama pada semi vokal, yaitu bunyi [ya]. Perbedaan yang terlihat terdapat bunyi konsonan plosif [k] yang kemudian berubah menjadi konsonan frikatif [t]. Selanjutnya, kata suranpu muncul. Yang membedakan dari kata kyanpu dan chanpu adalah perubahan konsonan jentik [r] dan penambahan mora [su]. Di sisi lain, kata bagupaipu hanya memiliki satu bunyi yang sama dengan tiga kata sebelumnya, yaitu bunyi mora [pu]. Kemudian, kata gooyachanpuru memiliki tiga bunyi mora yang sama dengan kata sebelumnya, yaitu chanpu. Perbedaan yang terlihat yaitu terdapat penambahan bunyi mora [go], vokal panjang [:], semi vokal [ya], dan mora [ru]. Namun, maknanya berbeda dengan kata chanpu.
Sudah disebutkan sebelumnya bahwa kata referen memiliki makna berkemah. Namun, kata chanpu yang berasal dari kata champion atau dalam kata bahasa Inggris champion yang bermakna juara atau pemenang. Selanjutnya, suranpu yang berasal dari istilah bahasa Inggris, slump, yang memiliki makna 'kemerosotan'. Bagupaipu pula berasal dari istilah bahasa Inggris pula, yaitu bagpipe. Bagpipe merupakan sebuah alat musik pipa yang dibunyikan oleh udara yang berasal dari tas yang ditekan oleh lengan pemain. Alat tersebut memiliki kaitan dengan negara Skotlandia. Chanpu, suranpu, dan bagupaipu termasuk ke dalam jenis gairaigo, di mana istilah-istilah tersebut mengambil dari istilah bahasa asing. Lalu, chanpu merupakan proses dari penyingkatan atau akronim dari kata chanpion. Terakhir, gooyachanpuru, adalah makanan khas Okinawa. Makanan tersebut merupakan "campuran" antara sayur, ikan, atau pun daging.

Ciri khas selanjutnya, embbed dajare dari kelompok di atas adalah yang diberi warna biru, yaitu kata referen chanpu dan kata targetnya mengambil dari bunyi kata referen menjadi kata gooyachanpuru. Di dalam kata gooyachanpuru sendiri tidak mengandung sama sekali makna 'juara' seperti yang sudah dijelaskan sebelumnya. Maknanya berbeda jauh dari kata referen.

Kelompok kata embed dajare selanjutnya dapat dilihat pada Gambar 2 berikut.

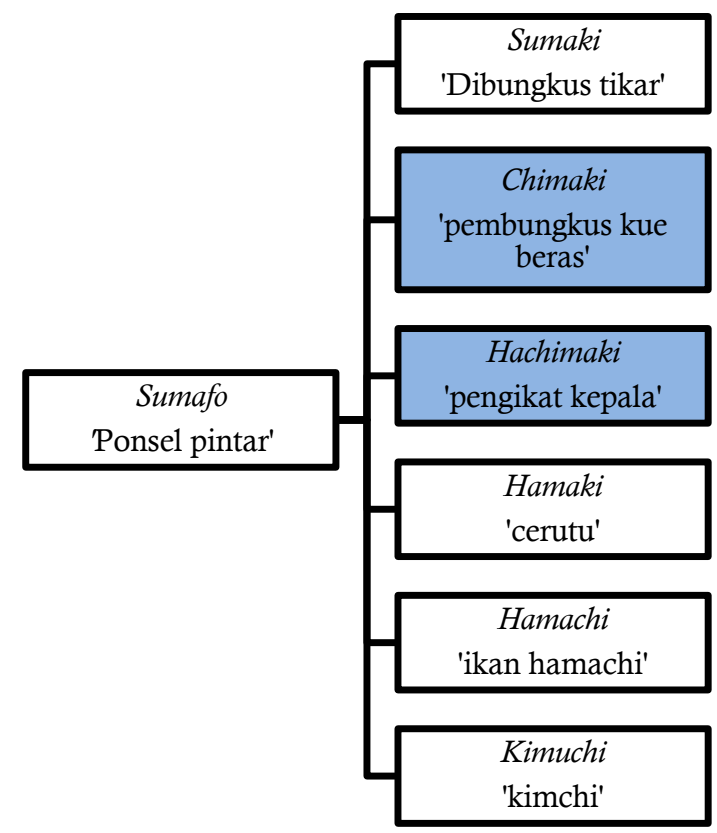

Gambar 2: Proses perubahan bunyi (hen'on) dajare pada episode empat. 
Gambar 2 merupakan contoh kedua dari klasifikasi embbed dajare. Keenam kata di atas memiliki bunyi-bunyi yang sama dan serupa. Kata referensi dari empat kata tersebut adalah kata sumafo, berasal dari istilah bahasa Inggris, smartphone, yang bermakna ponsel pintar. Kata sumafo termasuk ke dalam jenis kata gairaigo, di mana katanya diambil dari istilah bahasa asing serta mengalami proses penyingkatan dari kata sumaatofon menjadi kata sumafo.

Ciri khas dari kelompok kata ini terlihat dari persamaan bunyi konsonan bilabial nasal [m]. Kemudian, ciri khas selanjutnya yaitu kecenderungan bunyi mora [ma] dan [ki] Walaupun begitu, masing-masing kata memiliki maknya sendiri.

Kata referen sumafo dapat berubah menjadi kata sumaki karena keduanya memiliki bunyi yang sama pada dua mora, yaitu bunyi [su] dan [ma]. Perbedaan yang terlihat terdapat bunyi mora [fo] yang kemudian berubah menjadi mora [ki]. Selanjutnya, kata chimaki, hachimaki, dan hamaki muncul. Kata referen dari tiga kata tersebut adalah kata sumaki. Persamaan yang dimiliki oleh keempat kata tersebut adala bunyi mora [ma] dan [ki]. Perbedaan bunyi yang terlihat adalah perubahan dari bunyi mora [su] berubah menjadi mora [chi] pada kata chimaki, lalu ada penambahan bunyi mora [ha] pada kata sebelumnya menjadi hachimaki, kemudian penghilangan bunyi mora [chi] dari kata sebelumnya menjadi hamaki.

Kemunculan kata hamachi pun muncul dari kata referen hamaki. Perbedaan yang terlihat dari dua kata tersebut, yaitu adanya perubahan konsonan plosif [k] menjadi konsonan frikatif [t]]. Selanjutnya, muncul kata kimuchi. Kata tersebut berasal dari kata referen hamachi. Persamaan yang terlihat dari dua kata tersebut, yaitu adanya bunyi mora [chi]. Perbedaannya dari perubahan mora [ha] dan [ma] menjadi mora [ki] dan [mu]. Lalu, perubahan bunyi chimaki kepada hachimaki mengalami hen'on genshou, yaitu on'in tenka, bunyi yang tidak ada di elemen asli ditambahkan ke dalam kata-kata yang dibentuk, dengan menambahkan bunyi [ha]

Sudah disebutkan sebelumnya bahwa kata referen untuk lima kata target memiliki makna ponsel pintar. Namun, kata sumaki memiliki makna 'digulung atau dibungkus dengan tikar'. Zaman dahulu, istilah sumaki digunakan untuk membungkus seseorang, lalu membuangnya ke sungai sebagai sebuah hukuman. Chimaki memiliki makna 'kue yang dibungkus daun bambu'. Di sisi lain, hachimaki memiliki sedikit perbedaan dari kata chimaki. Kata tersebut memiliki makna 'ikat kepala'. Lalu, kata hamaki memiliki makna 'cerutu'. Hamachi bermakna 'sejenis ikan bersirip kuning'. Kemudian, yang terakhir adalah kata kimuchi, berasal dari kata kimchi yang merupakan makanan khas negara Korea, yaitu, acar kubis. Kimuchi termasuk ke dalam jenis kata gairaigo, karena istilah tersebut diambil dari kata bahasa asing.

Ciri khas selanjutnya, embbed dajare dari kelompok di atas adalah yang diberi warna biru, yaitu kata referen chimaki dan kata targetnya mengambil dari bunyi kata referen menjadi kata hachimaki. Di dalam kata chimaki dan hachimaki sendiri sama-sama memiliki makna untuk 'membungkus'. Hanya saja, chimaki digunakan untuk membungkus kue beras, sedangkan hachimaki diperuntukkan sebagai pengikat di kepala.

Lalu, kelompok kata embbed dajare selanjutnya terdapat pada gambar 3 yang merupakan contoh ketiga dari klasifikasi embbed dajare.

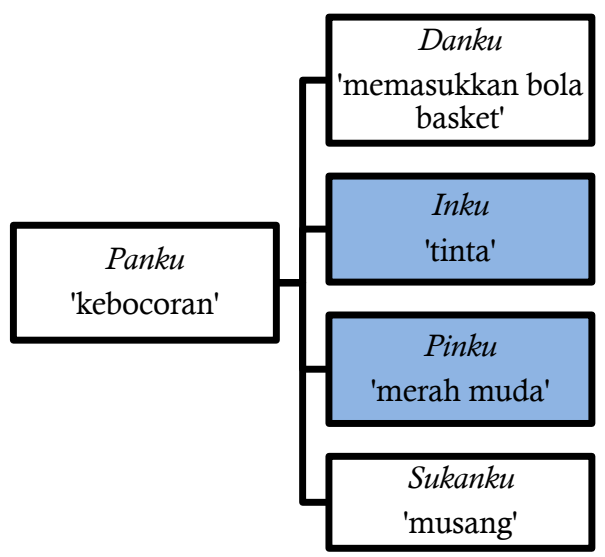

Gambar 3: Proses dajare pada episode empat.

Keempat kata di atas memiliki bunyi-bunyi yang serupa. Kata referensi dari empat kata tersebut adalah kata panku yang bermakna 'kebocoran'.

Ciri khas dari kelompok kata ini terlihat dari pertemuan bunyi hatsuon [n] dengan mora [ku] yang kemudian menghasilkan bunyi konsonan nasal ["].

Kata referen panku yang berubah menjadi kata danku dilihat dari perbedaan bunyi konsonan bilabial tak bersuara [p] menjadi bunyi konsonan plosif tak bersuara [d]. Selanjutnya, kata inku dan pinku muncul. Vokal [a] yang terdapat pada kata panku dan danku kini berubah menjadi vokal [i] dan 
menghilangkan konsonan [p] dan [d], yang akhirnya kata inku pun hadir. Lalu, kata pinku berasal dari bunyi kata inku dengan penambahan konsonan bilabial tak bersuara, yaitu bunyi [p]. Di sisi lain, kata sukanku memiliki bunyi yang sama seperti panku dan danku. Hanya saja, kata tersebut menambahkan bunyi mora [su] dan bunyi konsonan plosif tidak bersuara [k]. Lalu, perubahan bunyi inku kepada pinku mengalami hen'on genshou, yaitu on'in tenka, bunyi yang tidak ada di elemen asli ditambahkan ke dalam kata-kata yang dibentuk.

Sudah disebutkan sebelumnya bahwa kata referen dari empat kata target memiliki makna 'kebocoran'. Namun, kata danku berasal dari istilah bahasa Inggris, dunk, yang bermakna 'memasukkan bola basket'. Lalu, kata inku, pinku, dan sukanku pula berasal dari istilah bahasa Inggris yang memiliki makna 'tinta', 'merah muda', dan 'musang'. Istilah danku, inku, sukanku, dan pinku termasuk ke dalam jenis kosakata gairago, di mana keempatnya mengambil dari istilah bahasa asing (bahasa Inggris).

Ciri khas selanjutnya, embbed dajare dari kelompok di atas adalah dua kata di dalam kotak yang diberi warna biru, yaitu kata referen inku dan kata targetnya mengambil dari bunyi kata referen, yaitu pinku. Di dalam kata pinku sendiri tidak mengandung sama sekali makna 'tinta' seperti yang sudah dijelaskan sebelumnya. Maknanya berbeda dengan kata referen yang mengandung kata benda konkrit.

\section{SIMPULAN}

Dajare merupakan permainan kata yang mengandalkan bunyi-bunyi terkecil. Jika dari kata referen dan kata target memiliki bunyi yang berbeda maka makna yang terkandung dalam masing-masing target pun cenderung berbeda. Untuk embbed dajare sendiri, bunyi-bunyi yang dimiliki oleh kata target sama dengan bunyi kata referen tidak menjamin kesamaan makna. Maka kesamaan atau kemiripan bunyi serta bentuk tidak menjamin kesamaan makna dari kata referen dan kata target. Jika ada pun, hubungan makna antara kata referen dan kata target memiliki keterkaitan satu sama lain. Sebagai implikasi dari hasil penelitian, diharapkan hasil penelitian ini dapat membantu dalam pembelajaran bahasa Jepang di dalam berbagai aspek, seperti dalam kemampuan berbicara dan penambahan kosakata, serta pola permainan yang membantu dalam penguatan memori dalam mengingat kosakata apa saja yang sudah didapatkan atau dipelajari.

\section{REFERENSI}

Berger, A. A. (2011). The Art of Comedy Writing. New Jersey: Transaction Publishers.

Chaer, A., \& Agustina, L. (2014). Sosiolinguistik. Jakarta: Rineka Cipta.

Dybala, P., Rzepka, R., Araki, K., \& Sayama, K. (2012). Japanese puns are not necessarily jokes. AAAI Fall Symposium - Technical Report, FS-12-02, 7-13. Retrieved from AAAI.

Fadilah, N. (2017). Pembentukan Dan Makna Kontekstual Dajare Pada Serial Kartun Doraemon Episode 452 (ダジャレでやっつけろ！). Goken, 5(3), 1-8. Retrieved from Jurnal mahasiswa Unesa.

Giorgadze, M. (2014). Linguistic Features of Pun, Its Typology, and Classification. European Scientific Journal, 2 (special), 271-275. Retrieved from European Scientific Journal.

Human Academy. (2014). Nihongo Kyouiku Nōryoku Kentei Shiken Kanzen Kouryaku Gaido (3th ed., pp. 41). Retrieved from Google Book.

Leech, G. (2003). Semantik. Yogyakarta: Pustaka Belajar. Mahsun. (2017). Metode Penelitian Bahasa. Depok: PT. Rajagrafindo Persada.

Otake, T. (2010). Dajare is more Flexible than Puns: Evidence from Word Play in Japanese. Journal of the Phoetic Society of Japan, 14(1), 76-85. https://doi.org/10.24467/onseikenkyu.14.1_76

Shinohara, K. (2009). Designing Languange Games. Japanese Society for the Science of Design, 16-2(62). 4449.

Viera, R. T. (2017). Vocabulary Knowledge in The Production of Written Texts: A Case Study on EFL Language Learners. Revista Tecnologica ESPOL - RTE, 30(3). 89-105. Retrieved from Revista Tecnologica. 


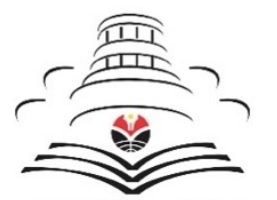

JURNAL UPI
JAPANEDU:

Jurnal Pendidikan dan Pengajaran Bahasa Jepang

http://ejournal.upi.edu/index.php/japanedu/index

\title{
Interactive Learning Medium Development for Learning Hiragana and Katakana
}

\author{
Desak Made Sri Mardani, I Wayan Sadyana, Putu Hendra Suputra \\ Japanese Language Department, Universitas Pendidikan Ganesha, Singaraja, Indonesia \\ desak.mardani@undiksha.ac.id
}

\begin{abstract}
A B S T R A C T
The ability of college students in X university to use Hiragana and Katakana letters is still weak due to the lack of practice in reading and using these letters in a word/sentence. The ability to use Hiragana and Katakana letters is not only about the ability to understand the order of writing and the differences in the strokes, but also to use Hiragana and Katakana in words/sentences. This research was a descriptive study using R \& D design based on the Four-D Model. In this study, three stages were carried out out of the four stages of the model. Questionnaires and interviews were used in this study as a method of data collection. Interviews also conducted to determine the needs of teachers and students, while questionnaire was used for expert judgement (expert appraisal) process consisting of learning media expert judgement and content expert judgement. The questionnaire data were analyzed descriptively to determine deficiencies in the media created. After going through the improvement phase, then a limited scale trial was conducted on 26 students. From the questionnaire data on the interactive media produced, it is known that overall, the media produced received excellent responses from students, wherein each assessment indicator also received a positive response as well. However, further studies are needed to find out how to implement the interactive media of Hiragana and Katakana in the learning process directly inside the classroom.
\end{abstract}

\section{K E Y W O R D S}

Expert appraisal; Hiragana; Interactive media; Katakana; R \& D design

First received: 16 August 2019

A R T I C L E I N F O

Available online: 20 June 2020

Final proof accepted: 4 March 2020

\section{PENDAHULUAN}

Media pembelajaran merupakan alat bantu dalam proses belajar mengajar yang memiliki fungsi untuk menyampaikan isi atau materi yang ingin disampaikan oleh pengajar, sehingga informasi/ilmu tersebut dapat dipahami oleh pembelajar. Dalam proses pembelajaran, penggunaan media pembelajaran merupakan salah satu faktor penentu keberhasilan pembelajar dalam menguasai materi pembelajaran. Hal tersebut dapat terlihat dari berbagai manfaat dalam penggunaan media pembelajaran yaitu: membuat konkret konsepkonsep yang abstrak, menghadirkan objek yang tidak mungkin dihadirkan di kelas, menampilkan objek yang terlalu besar atau terlalu kecil, serta 
memperlihatkan gerakan yang terlalu cepat atau lambat (Susilana \& Ruyana, 2009). Dengan demikian, media pembelajaran sebaiknya dikembangkan sesuai dengan materi/objek pembelajaran.

Pengembangan media pembelajaran dapat dilakukan oleh pengajar atau pengajar dapat menggunakan media yang telah dipasarkan di masyarakat. Pengajar merupakan kunci dalam peningkatan mutu pendidikan dan mereka berada di titik sentral dari setiap usaha reformasi pendidikan yang diarahkan pada perubahan-perubahan kualitatif. Seperti yang disampaikan oleh Elliot (2000) bahwa pengetahuan mendasar yang harus dikuasai oleh seorang pengajar adalah pengetahuan terkait bagaimana mengajar materi yang terbaik (Teaching (Pedagogical) Knowledge), tata cara dalam mengorganisasi dan strategi dalam menyampaikan materi (Subject Matter Knowledge) serta bagaimana materi ajar tersebut dapat dipahami oleh siswa (Teaching Subject Matter Knowledge). Oleh sebab itu seorang pengajar perlu memiliki kemampuan untuk menyediakan, mengolah dan mengatur pengetahuan agar tersampaikan dan diterima dengan baik oleh pembelajar, salah satunya dengan penggunaan media pembelajaran dalam proses belajar. Dengan penggunaan media pembelajaran, maka akan tercipta pembelajaran yang menarik. Media memberikan pengalaman belajar yang menarik melalui penyediaan akses yang lebih luas kepada pembelajar, salah satunya adalah media pembelajaran berbasis Teknologi Informasi dan Komputer (TIK). Media Berbasis TIK sudah banyak dikembangkan oleh pengajar dari segala bidang ilmu. Alessi dan Trollip (dalam Istiqlal, 2017) menyampaikan bahwa ratusan penelitian telah membuktikan bahwa penggunaan komputer pada pembelajaran lebih baik bila dibandingkan dengan penggunaan buku, pengajar, film, atau metode tradisional lainnya. Penelitian-penelitian tentang pendidikan telah membuktikan bahwa menggunakan komputer untuk mengajar lebih baik dari menggunakan buku, guru, film atau metode tradisional lainnya. Seperti yang disampaikan oleh Ghavifekr dan Rosdy (2015) bahwa integrasi TIK (proses belajar mengajar berbasis teknologi) efektif terhadap guru dan siswa dalam proses pembelajaran. Lebih lanjut Alessi dan Trollip (dalam Istiqlal, 2017) menyebutkan bahwa pengajar harus menggunakan berbagai macam bahan berbasis multimedia dan pendekatan dalam pembelajaran, serta menyediakan lingkungan belajar yang fleksibel sesuai dengan kebutuhan sebagian besar pembelajarnya. Oleh sebab itu, dengan bantuan komputer pengajar dapat menyediakan lingkungan belajar yang fleksibel sesuai dengan kebutuhan pembelajarnya.
Penguasaan pembuatan dan pemanfaatan media pembelajaran berbasis TIK sangat diperlukan terutama pada pembelajaran yang menekankan penjelasan proses. Program presentasi seperti Microsoft Power Point mampu menyajikan materi dengan instan dan mudah dengan berbagai template yang dimiliki, tetapi tidak mampu menunjukkan suatu materi yang mengandung sebuah proses (Mardani \& Suputra, 2016). Seperti misalnya dalam pembelajaran menulis huruf Jepang di Prodi Pendidikan Bahasa Jepang di salah satu universitas di Indonesia.

Kompetensi dalam menulis huruf Jepang di Prodi Pendidikan Bahasa Jepang tersebut sedikit berbeda bila dibandingkan dengan jurusan bahasa Jepang atau sastra Jepang yang ada di universitas lain. Menulis huruf Jepang khususnya Hiragana dan Katakana, diberikan pada mata kuliah Hyouki. Hyouki memiliki beban 2 sks dengan standar kompetensi agar mahasiswa memiliki kompetensi tentang keterampilan menulis huruf Jepang sesuai dengan aturan penulisan serta indah agar nantinya mampu mengajarkan siswa dengan baik dan benar pula, mengingat bahwa lulusan prodi merupakan calon pengajar.

Untuk mencapai kompetensi tersebut, dalam proses pembelajaran ditekankan penulisan huruf sesuai dengan aturan penulisan yang benar pada urutan penulisan huruf, serta keindahan huruf yang meliputi goresan huruf dan keseimbangan huruf. Dengan demikian penguasaan huruf Jepang tidak hanya menekankan pada penguasaan bentuk dan urutan penulisan huruf tetapi juga pada keindahan dari huruf itu sendiri (Mardani, 2012).

Untuk mencapai kompetensi seperti di atas maka penggunaan media pembelajaran berbasis TIK sangat membantu, seperti yang telah diperoleh dalam penelitian yang dilakukan oleh Mardani (2012) tentang penggunaan media visual berbasis TIK untuk meningkatkan kemampuan menulis huruf Hiragana dan Katakana. Dari hasil penelitian tersebut dapat diketahui bahwa media visual dapat membantu pembelajar dalam membedakan goresan dalam penulisan huruf Jepang, karena penggunaan media visual memungkinkan terlihatnya bentuk goresan dan urutan dalam penulisan. Pada penelitian tersebut digunakan warna yang berbeda pada goresan yang berbeda. Warna hitam untuk goresan yang ditulis berhenti di akhirnya (tomarimasu), warna biru untuk goresan yang ditulis lepas (haraimasu) serta warna hijau untuk goresan yang ditulis seperti percikan air (hanemasu). Selain media visual, pada penelitian tersebut digunakan pula metode tugas. Efektifitas media visual dan metode tugas tersebut terlihat dari peningkatan kemampuan menulis dan respon positif dari pembelajar terhadap penggunaan media visual. 
Penggunaan media visual dan metode tugas pada pembelajaran huruf Hiragana dan Katakana tersebut telah dilakukan secara berkesinambungan. Tidak hanya terbatas pada pembelajaran huruf Hiragana dan Katakana, namun juga digunakan pada pembelajaran huruf Kanji. Dalam hal penguasaan goresan dan urutan penulisan huruf, mahasiswa sudah tidak mengalami kendala. Tetapi ketika dihadapkan dengan pengaplikasian/penggunaan huruf dalam kata maupun kalimat, kemampuan mahasiswa masih kurang. Hal tersebut terlihat dari hasil pembelajaran huruf Hiragana dan Katakana pada mahasiswa tingkat satu di Prodi Pendidikan Bahasa Jepang, di salah satu universitas di Indonesia pada tahun ajaran 2018/2019. Dari tugas penulisan huruf yang menekankan pada keindahan dan urutan penulisan, dapat diketahui bahwa mahasiswa mampu melaksanakan dengan baik, begitu pula jika dimunculkan pada tes kecil di awal pelajaran. Tetapi, ketika mahasiswa dihadapkan pada penulisan huruf dalam sebuah kata maupun kalimat terlihat beberapa mahasiswa kurang menguasai huruf.

Pengajar merasakan kekurangan dalam penggunaan media visual sehingga memerlukan media yang lainnya. Media pembelajaran dapat dikelompokkan menjadi tiga kategori yaitu (1) media penyaji; (2) media objek; (3) media interaktif. Media pembelajaran interaktif dapat didefinisikan sebagai kombinasi dari berbagai media yang dikemas (diprogram) secara terpadu dan interaktif untuk menyajikan pesan pembelajaran tertentu (Purwanto \& Kusnandar dalam Lia, 2015). Media interaktif menuntut pembelajar untuk berinteraksi dengan media tersebut selama proses pembelajaran. Susilana dan Riyana (2009) mengungkapkan terdapat tiga jenis interaksi dalam penggunaan media interaktif, meliputi:

a. Pembelajar berinteraksi dengan sebuah program, contoh ketika mengisi blanko pada bahan belajar terprogram;

b. Pembelajar berinteraksi dengan mesin, contoh mesin pembelajaran, simulator, laboratorium bahasa, komputer atau kombinasi yang berbentuk video interaktif;

c. Mengatur interaksi antara pembelajar secara teratur tapi tidak terprogram, contoh pada permainan pendidikan atau simulasi yang melibatkan pembelajar dalam kegiatan atau masalah yang mengharuskan mereka untuk membalas serangan lawan atau bekerjasama dengan teman sekelompok dalam memecahkan masalah.

Purwanto dan Kusnandar (dalam Lia, 2015) menjelaskan bahwa program multimedia interaktif memiliki sejumlah kelebihan dibanding dengan media lainnya, yaitu:
1) Fleksibel, artinya pemberian kesempatan untuk memilih isi setiap bidang yang disajikan dan juga fleksibel dalam waktu dan penggunaannya.

2) Self-pacing, artinya bersifat melayani kecepatan belajar individu.

3) Content-rich, artinya program menyediakan informasi yang cukup banyak.

4) Interaktif, artinya program memberikan kesempatan kepada pengguna untuk memberikan respon yang akhirnya akan direspon oleh multimedia.

5) Individual, artinya program sudah dirancang dan disediakan untuk memenuhi minat kebutuhan individu.

Dengan memahami berbagai kelebihan dari media pembelajaran interaktif tersebut, pengembangan media pembelajaran interaktif dapat dilakukan untuk memfasilitasi pembelajaran seperti halnya pembelajaran huruf Hiragana dan Katakana.

Media interaktif yang diperlukan oleh pengajar adalah media yang mampu digunakan dalam proses penguasaan huruf Hiragana dan Katakana, yang bukan hanya memunculkan urutan dan goresan tulisan. Media pembelajaran interaktif yang bukan hanya sekedar pengenalan huruf dan cara penulisannya saja (seperti dilakukan sebelumnya dengan media visual) tetapi mengarah pada contoh penggunaan huruf tersebut serta latihan-latihan yang mampu merangsang kemampuan pembelajar untuk mengingat huruf dengan tepat dan cepat. Oleh sebab itu, sangat penting dilakukan pengembangan media pembelajaran interaktif untuk penguasaan huruf Hiragana dan Katakana.

Terkait pengembangan media pembelajaran interaktif sudah banyak dilakukan oleh peneliti lain pada segala bidang ilmu. Seperti misalnya pembuatan media interaktif pembelajaran bahasa Inggris dalam mengenalkan huruf dan membaca untuk anak SD yang dilakukan oleh Maesaroh dan Malkiah (2015). Media tersebut diketahui mampu menambah pengetahuan dan kemampuan dalam berbahasa Inggris dalam level anak kelas satu sekolah dasar. Terkait pembelajaran bahasa Inggris di tingkat $\mathrm{SD}$, sebelumnya telah dikembangkan pula media interaktif pembelajaran bahasa Inggris untuk jenjang kelas dua SD oleh Sari dan Sasongko (2013). Pengembangan media interaktif ini untuk memudahkan penyampaian materi atau pelajaran kepada siswa kelas dua SD.

Dari hasil pengembangan tersebut dapat diketahui bahwa dengan media pembelajaran interaktif, pembelajaran lebih menarik dan pesan/materi dapat tersampaikan dengan baik. Dengan melihat betapa pentingnya penguasaan huruf Hiragana dan Katakana bagi pembelajar pemula, maka diperlukan sebuah media interaktif 
yang mampu membantu pembelajar agar dapat menguasai huruf tersebut dengan benar dan cepat sesuai dengan aturan penulisan huruf Jepang. Hal tersebut menjadi sangat penting mengingat penguasaan huruf Jepang dalam hal menulis yang sesuai dengan aturan menjadi keunggulan di Prodi Pendidikan Bahasa Jepang di salah satu universitas di Indonesia yang menjadi sampel dalam penelitian ini. Pengembangan media ini dirasa sangat membantu dalam proses pembelajaran huruf Hiragana dan Katakana baik dari pihak pengajar maupun pembelajar. Dengan penelitian ini, maka salah satu kompetensi yang ingin dimiliki oleh lulusan Prodi Pendidikan Bahasa Jepang tersebut akan tercapai.

\section{METODE PENELITIAN}

Penelitian ini merupakan penelitian deskriptif dengan menggunakan rancangan R \& D yaitu Four$D$ Model dari Thiagarajan, S., dkk (1974). Menurut Sutedi (2009) penelitian deskriptif dilakukan untuk menggambarkan, menjabarkan, suatu fenomena yang terjadi saat ini dengan menggunakan prosedur ilmiah untuk menjawab masalah secara aktual. Berdasarkan Four-D Model maka dilakukan beberapa tahapan dalam penelitian.

Pada tahap pertama (tahap Define) dilakukan analisis kebutuhan dari sisi pengajar dan pembelajar. Dari hasil analisis diketahui bahwa diperlukan media yang bukan saja mampu memperlihatkan urutan penulisan dan goresan tetapi juga memberikan contoh penggunaan huruf pada sebuah kata.

Setelah tahap pertama selesai dilanjutkan dengan tahap kedua (tahap Design), dimana pada tahap ini hasil analisis pada tahap satu direalisasikan menjadi media pembelajaran yang memang dibutuhkan oleh dosen pengampu mata kuliah Hyouki yang disesuaikan pula dengan tuntutan universitas yaitu penggunaan teknologi informasi dalam pembelajaran. Dilakukan pembuatan prototipe dari media interaktif huruf Hiragana dan Katakana. Pada proses pembuatan dipergunakan Adobe Flash CS6.

Pada tahap ketiga (tahap Develop) dilakukan uji ahli (Expert appraisal) yang terdiri dari uji ahli media pembelajaran dan uji ahli isi. Feedback dari ahli digunakan untuk memperbaiki agar bahan pembelajaran lebih tepat, efektif, bermanfaat, serta memiliki teknik yang berkualitas. Setelah dilakukan uji ahli, media yang sudah diperbaiki berdasarkan masukan ahli memasuki tahap Developmental testing. Pada tahap ini dilakukan ujicoba pada skala terbatas kepada mahasiswa agar mengetahui respon mereka terhadap media yang dibuat. Tahap ketiga (tahap
Develop) ini merupakan tahap pengukuran efektivitas media pembelajaran interaktif huruf Hiragana dan Katakana.

Pada penelitian ini, tahap ke empat (Disseminate/penyebaran) tidak dilakukan mengingat keterbatasan waktu penelitian.

Dalam penelitian ini, subjek penelitian adalah dosen pengampu mata kuliah Hyouki di Prodi Pendidikan Bahasa Jepang, di salah satu universitas di Indonesia, serta mahasiswa. Sedangkan objek penelitian ini adalah media pembelajaran interaktif huruf Hiragana dan Katakana.

Dalam hal teknik penelitian, pada tahap pertama dilakukan wawancara terhadap pengajar mata kuliah Hyouki serta beberapa mahasiswa untuk mengetahui media seperti apa yang dibutuhkan oleh pengajar dan pembelajar. Pada tahap ketiga (tahap Develop) yaitu uji ahli (Expert appraisal) yang terdiri dari uji ahli media pembelajaran dan uji ahli isi, dua orang ahli akan diberikan angket terkait penilaian terhadap media yang dihasilkan. Data angket tersebut dianalisis secara deskriptif untuk mengetahui kekurangan dalam media yang dibuat. Setelah melewati tahap perbaikan, dilakukan ujicoba dalam skala terbatas terhadap 26 orang mahasiswa, Mahasiswa diberikan angket untuk melihat respon mereka terhadap media yang dihasilkan, terbatas pada tampilan media dan kejelasan goresan huruf. Data dari angket tersebut kemudian dianalisis. Adapun tahapan yang dilakukan dalam analisis data angket adalah sebagai berikut.

Menghitung interpretasi skor pada masingmasing pernyataan dengan penghitungan sebagai berikut:

$$
\text { Interval }(I)=\frac{\text { Jumlah total skor pertanyaan }}{\text { Jumlah total skor maksimal pertanyaan }} \times 100 \%
$$

Menentukan kategori respon pembelajar (lihat Tabel 1) terhadap media dengan menggunakan kriteria respon yang diungkapkan oleh Khabibah (dalam Yamasari, 2010).

Tabel 1: Kategori respon pembelajar.

\begin{tabular}{|l|l|}
\hline \multicolumn{1}{|c|}{ Persentase } & \multicolumn{1}{c|}{ Kategori } \\
\hline $\mathrm{I} \geq 85 \%$ & Sangat Positif \\
\hline $70 \% \leq \mathrm{I} \leq 85 \%$ & Positif \\
\hline $50 \% \leq \mathrm{I} \leq 70 \%$ & Kurang Positif \\
\hline $\mathrm{I}<50 \%$ & Tidak positif \\
\hline
\end{tabular}




\section{HASIL DAN PEMBAHASAN}

\section{Pengembangan Media Interaktif}

Dari hasil penelitian diketahui bahwa dalam pengembangan media interaktif perlu penambahan kosakata sebagai bahan latihan untuk pembelajar dalam belajar huruf Hiragana dan Katakana.

Pada pembuatan media pembelajaran interaktif ini digunakan Adobe Flash CS6, hal ini untuk memudahkan pembuatan urutan penulisan huruf. Mengacu pada hasil penelitian Mardani (2012), penggunaan warna yang berbeda pada goresan pembentuk huruf dapat membantu pembelajar menghasilkan huruf yang indah, maka pada pengembangan media ini juga digunakan warna yang berbeda pada masing-masing goresan. Adapun goresan dasar yang terdapat pada huruf Hiragana dan Katakana meliputi haraimasu (goresan dengan melepas pada akhir tulisan), tomarimasu (goresan dengan menghentikan tangan), hanemasu (goresan seperti percikan air). Goresan-goresan tersebut menggunakan warna berbeda seperti Gambar 1.

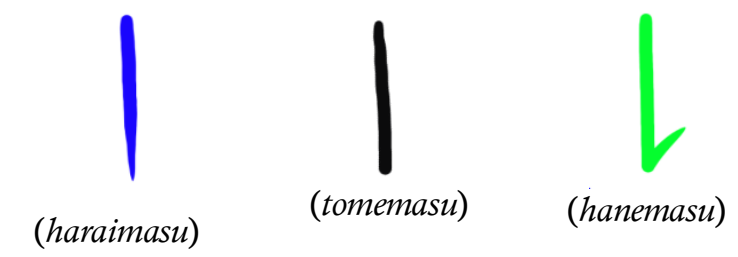

Gambar 1: goresan dasar yang terdapat pada huruf Hiragana dan Katakana.

Setelah prototipe media dihasilkan, dilakukan uji ahli media dan ahli isi, di mana diperoleh beberapa masukan. Adapun masukan yang diberikan oleh ahli lebih pada contoh kosakata yang digunakan serta tata letak kosakata tersebut dalam tampilan layar. Berdasarkan masukan dari ahli tersebut maka kosakata yang digunakan lebih banyak menggunakan kata benda dan merupakan kosakata yang berada di lingkungan pembelajar/mahasiswa. Hal ini untuk memudahkan pembelajar dalam memahami kosakata yang diberikan sehingga mereka dapat secara langsung menghubungkan antara tulisan dan makna kosakata tersebut. Untuk beberapa kosakata digunakan kosakata dari kata kerja. Kata kerja yang digunakan terbatas pada kata kerja yang sering dilakukan/digunakan oleh pembelajar, sehingga pemaknaan kata pun akan lebih mudah. Dalam hal tata letak kosakata, pada setiap tampilan layar dimunculkan beberapa kosakata dengan pemberian jarak yang sesuai agar pembelajar dapat melihat dengan baik contoh kata yang diberikan. Dengan memberikan hanya beberapa kosakata dalam satu tampilan layar diharapkan pembelajar tidak merasa terbebani.

Adapun media interaktif yang dihasilkan dalam pengembangan ini seperti terlihat pada penjelasan berikut.

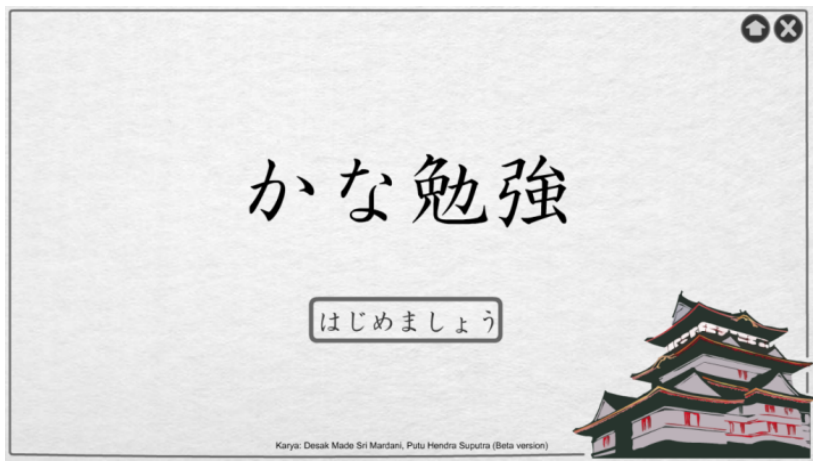

Gambar 2: Desain latar yang sederhana.

Pada media digunakan desain latar yang sederhana (Gambar 2). Hal ini dimaksudkan agar pembelajar menjadi fokus terhadap huruf Hiragana dan Katakana dalam pembelajaran, tanpa gangguan dari latar belakang yang berlebihan. Letak judul, silabel ataupun contoh kosakata dan kalimat disesuaikan dengan jumlah kemunculannya di satu layar. Hal tersebut untuk memanfaatkan ruang dengan baik, sehingga tampilan layar terlihat rapi dan memudahkan pembelajar untuk melihat dan membedakan huruf yang muncul. Mengingat banyaknya huruf Hiragana dan Katakana yang mirip satu dengan lainnya sehingga menyebabkan pembelajar kesulitan dalam membedakannya. Seperti yang ditunjukkan dalam penelitian yang dilakukan oleh Listriani, Lispridona, dan Silvia (2018) bahwa pembelajar kesulitan dalam membedakan huruf Hiragana yang mirip bentuknya.

Setelah tombol ‘はじめましょう' diklik maka akan muncul tampilan Gambar 3. Masing-masing bagian 書き方，ひらがな dan かたかな akan dijelaskan lebih lanjut.

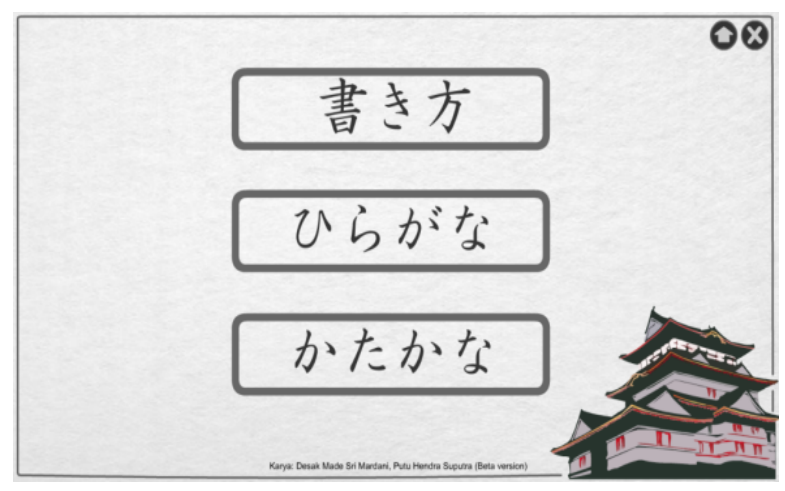

Gambar 3: Tampilan layar. 


\section{1. 書き方 (Kakikata)}

Pada 書き方 dijelaskan penggunaan warna yang berbeda pada masing-masing goresan pembentuk huruf yang digunakan pada media ini. Warna biru digunakan untuk goresan haraimasu, warna hitam untuk goresan tomarimasu, sedangkan warna hijau untuk goresan hanemasu. Dengan penjelasan tersebut, maka pengajar dan pembelajar dapat menggunakan media tersebut dengan mudah.

\section{2. ひらがな (Hiragana)}

Padaひらがな terdapat semua materi terkait huruf Hiragana meliputi silabel dasar, Dakuon, Handakuon, You'on, Chou'on, Sokuon dan penggunaan huruf Hiragana sebagai partikel. Contoh tampilan materi Hiragana seperti terlihat pada Gambar 4.

a. Silabel dasar

Pada bagian silabel dasar dimunculkan keseluruhan huruf dari a sampai n, dimana masing-masing silabel akan ditunjukkan urutan serta goresan pembentuk huruf tersebut.

b. Dakuon, Handakuon dan You'on

Urutan penulisan dan goresan diberikan pada setiap silabel dasar, sedangkan pada Dakuon, Handakuon, dan You'on tidak diberikan lagi. Pada tampilan layar dimunculkan silabel-silabel apa saja yang termasuk dalam kelompok Dakuon, Handakuon, dan You'on.

c. Chou'on dan Sokuon

Pada materi Chou'on, Sokuon, serta contoh kosakata langsung diberikan dalam satu tampilan layar. Hal ini berbeda dengan Dakuon, Handakuon, dan You'on yang terdiri dari banyak silabel sehingga contoh kata dimunculkan pada tampilan layar yang berbeda.

d. Penggunaan huruf Hiragana sebagai partikel

Seperti halnya Dakuon, Handakuon, You'on, Chou'on, dan Sokuon, pada tampilan huruf Hiragana sebagai partikel juga tidak dimunculkan urutan penulisan dan goresan huruf. Pada tampilan layar dimunculkan huruf Hiragana yang menjadi partikel beserta transliterasinya dalam huruf latin (bagian kiri layar), serta penggunaannya dalam sebuah kalimat (bagian kanan layar).

e. Contoh penggunaan huruf dalam kosakata dan kalimat

Pada masing-masing materi (silabel dasar, Dakuon, Handakuon, You'on, Chou'on, Sokuon dan penggunaan huruf Hiragana sebagai partikel) diberikan contoh kosakata dan kalimat. Hal ini memungkinkan untuk melatih pembelajar dalam mengingat huruf melalui kegiatan membaca. Tampilan contoh kosakata dan kalimat berbeda pada masing-masing materi seperti yang sudah dijelaskan pada masing-masing materi. Untuk kosakata dan kalimat yang dimunculkan tidak berbarengan dengan silabel yang dimaksud.

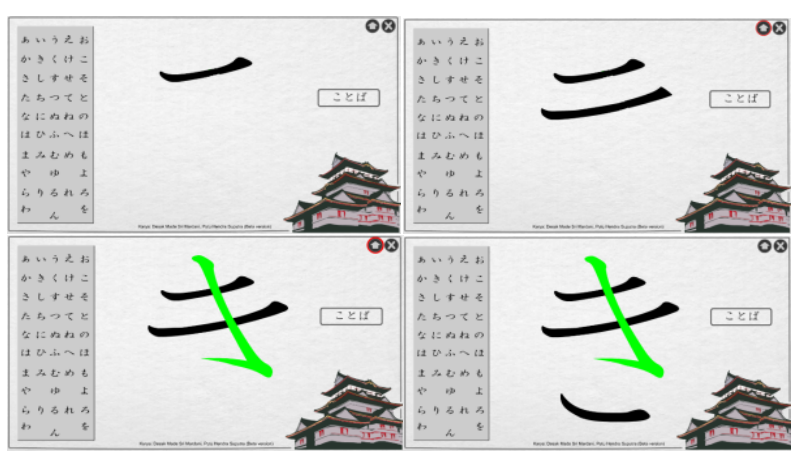

Gambar 4: Contoh tampilan huruf Hiragana

\section{3. かたかな (Katakana)}

Pada かたかな sama halnya seperti ひらがな, terdapat semua materi terkait huruf Katakana meliputi silabel dasar, Dakuon, Handakuon, You'on, Chou'on, dan Sokuon. Contoh tampilan materi Katakana seperti terlihat pada Gambar 5.

a. Silabel dasar

Pada materi silabel dasar, ditampilkan sama seperti pada Hiragana, dimana masing-masing huruf akan ditampilkan urutan penulisan serta goresan yang membentuk huruf tersebut.

b. Dakuon, Handakuon dan You'on

Seperti pada huruf Hiragana, hal yang sama juga dilakukan pada materi Dakuon, Handakuon dan You'on pada huruf Katakana, di mana tidakdiberikan kembali urutan penulisan dan goresan.

c. Chou'on dan Sokuon

Pada materi Chou'on dan Sokuon huruf Katakana sama seperti pada huruf Hiragana, di mana contoh kosakata langsung diberikan dalam satu tampilan layar. Hal ini disebabkan jumlah Chou'on dan Sokuon yang sedikit.

d. Silabel Tambahan

Terdapat kelompok silabel tambahanuntuk mengelompokkan silabel selain silabel dasar, Dakuon, Handakuon, You'on, Chou'on, dan Sokuon. Pada kelompok ini diberikan pula contoh kosakata yang sebagian besar adalah nama orang.

e. Contoh penggunaan huruf dalam kosakata

Pada silabel dasar, Dakuon, Handakuon, You'on, Chou'on, Sokuon dan silabel tambahan diberikan contoh kosakata. Melalui contoh ini pengajar dapat memberikan latihan kepada pembelajar dalam mengingat huruf melalui kegiatan membaca. Selain materi Chou'on, Sokuon, dan silabel tambahan, contoh kosakata diberikan secara terpisah pada layar karena 
jumlah silabel dari masing-masing materi tersebut banyak.
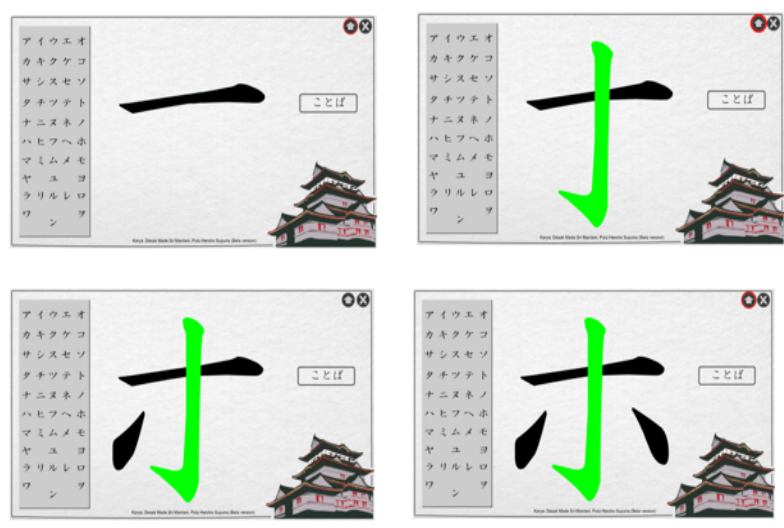

Gambar 5: Contoh tampilan huruf Katakana.

\section{Uji Coba Media Interaktif}

Setelah prototipe dari media disempurnakan, kemudian dilakukan uji coba lapangan dalam skala terbatas terhadap 26 orang mahasiswa yang terdiri dari angkatan yang berbeda (tingkat dua sampai tingkat lima) untuk mengetahui respon pembelajar terbatas pada tampilan media dan kejelasan goresan huruf. Ujicoba terkait efektivitas penggunaan media dalam membantu mahasiswa dalam proses pembelajaran belum dapat dilaksanakan. Adapun hasil analisis data angket seperti terlihat pada Tabel 2 .

Berdasarkan Tabel 2 dapat diketahui bahwa masing-masing indikator yang terdapat dalam penilaian dari media yang dihasilkan mendapat respon sangat positif dari mahasiswa. Berdasarkan tabel juga terlihat bahwa aspek yang paling tinggi mendapatkan respon dari mahasiswa adalah aspek isi dengan respon $95,85 \%$ berada pada kategori sangat positif. Sehingga secara keseluruhan pun media tersebut memperoleh respon yang sangat positif pula dengan nilai 93,24.

Tabel 2: Hasil analisis data angket.

\begin{tabular}{|l|c|l|}
\hline Indikator & Interval & Kategori Respon \\
\hline Aspek Pemrograman & & \\
\hline Kemudahan penggunaan program & $95 \%$ & Sangat Positif \\
\hline Kemudahan memilih menu program & $92 \%$ & Sangat Positif \\
\hline Kemudahan masuk dan keluar dari program & $92 \%$ & Sangat Positif \\
\hline Ketepatan reaksi button (tombol) & $89 \%$ & Sangat Positif \\
\hline Total Respon aspek pemrograman & $\mathbf{9 2 . 3 1 \%}$ & Sangat Positif \\
\hline Aspek Isi & & \\
\hline Goresan pada huruf terlihat jelas & $98 \%$ & Sangat Positif \\
\hline $\begin{array}{l}\text { Penggunaan warna sangat membantu dalam membedakan } \\
\text { Goresan }\end{array}$ & $98 \%$ & Sangat Positif \\
\hline Urutan goresan huruf terlihat jelas & $98 \%$ & Sangat Positif \\
\hline Contoh kosakata sesuai dengan materi & $91 \%$ & Sangat Positif \\
\hline Kejelasan tulisan (huruf Jepang) yang digunakan & $95 \%$ & Sangat Positif \\
\hline Total Respon aspek isi & $\mathbf{9 5 . 8 5 \%}$ & Sangat Positif \\
\hline Aspek Tampilan & & \\
\hline Tata letak huruf dan contoh kata baik & $90 \%$ & Sangat Positif \\
\hline Kesesuaian pemilihan background & $89 \%$ & Sangat Positif \\
\hline Kesesuaian pemilihan ukuran dan jenis huruf & $93 \%$ & Sangat Positif \\
\hline Kesesuaian warna & $\mathbf{9 7 \%}$ & Sangat Positif \\
\hline Kemenarikan tampilan tombol & $\mathbf{9 1 . 3 8 \%}$ & Sangat Positif \\
\hline Total Respon aspek tampilan & $\mathbf{9 3 , 2 4 \%}$ & Sangat Positif \\
\hline Respon keseluruhan & & \\
\hline
\end{tabular}




\section{KESIMPULAN DAN SARAN}

Berdasarkan hasil penelitian, diketahui bahwa media pembelajaran interaktif yang dihasilkan sudah memuat semua materi tentang Huruf Hiragana dan Katakana meliputi: silabel dasar, Dakuon, Handakuon, You'on, Chou'on, Sokuon, penggunaan huruf Hiragana sebagai partikel, serta silabel tambahan pada huruf Katakana. Media juga dilengkapi dengan pemberian kosakata yang masih berada di lingkungan pembelajar, sehingga pembelajar dapat lebih mudah mengaitkan antara huruf dan makna dari suatu kata. Berdasarkan hasil angket terkait respon mahasiswa terhadap media pembelajaran interaktif yang dihasilkan, diketahui bahwa secara keseluruan respon dari mahasiswa tergolong sangat positif. Pada penelitian ini baru sampai pada tahap uji coba lapangan dalam skala terbatas, oleh sebab itu uji coba implementasi dalam pembelajaran sangat penting untuk dilaksanakan.

\section{DAFTAR PUSTAKA}

Elliott, Stephen N. (2000). Educational Psychology: Effective Theaching, Effective Learning, The Mc. Graw-Hill Companies, Inc.: USA.

Ghavifekr, S. \& Rosdy, W.A.W. (2015). Teaching and learning with technology: Effectiveness of ICT integration in schools. International Journal of Research in Education and Science (IJRES), 1(2), 175-191. https://doi.org/10.46328/ijres.v1i2.79

Istiqlal, M. (2017). Pengembangan multimedia interaktif dalam pembelajaran matematika. Jurnal Ilmiah Pendidikan Matematika, 2(1). http://dx.doi.org/10.26877/jipmat.v2i1.1480

Lia, L. (2015). Multimedia interaktif sebagai salah satu alternatif pembelajaran dalam bidang pendidikan sains. Jurnal Inovasi dan Pembelajaran Fisika, 2(2). https://doi.org/10.36706/jipf.v2i2.2614
Listriani, Lispridona, D., \& Silvia, N. (2018). Analysis of difficulties student of class XI IPS SMA Taruna Nusantara in reading Hiragana. CHI'E: Journal of Japanese Learning and Teaching, 6(2), 64-67. https://doi.org/10.15294/chie.v6i2.22595

Maesaroh, S., \& Malkiah, N. (2015). Media pembelajaran interaktif bahasa Inggris pengenalan huruf dan membaca berbasis multimedia untuk Sekolah Dasar. Jurnal Sisfotek Global, 5(1). http://dx.doi.org/10.38101/sisfotek.v5i1.71

Mardani, D.M.S. (2012). Pemanfaatan media visual untuk meningkatkan kemampuan menulis huruf Hiragana dan Katakana. Jurnal Pendidikan dan Pengajaran, 45(3). http://dx.doi.org/10.23887/jppundiksha.v45i3.1836

Mardani, D.M.S., \& Suputra, P.H. (2016, Nopember). Meningkatkan kompetensi guru bahasa Jepang di kabupaten Buleleng melalui pelatihan pembuatan media pembelajaran penulisan huruf Jepang menggunakan animasi flash. Prosiding Seminar Nasional Pengabdian kepada Masyarakat (Senadimas), Sanur, Bali. Diakses dari http://eproceeding.undiksha.ac.id/index.php/senadi mas/article/view/380/267.

Sari, L.K., \& Sasongko, D. (2013). Media pembelajaran interaktif bahasa Inggris untuk siswa Sekolah Dasar kelas II. Seruni-Seminar Riset Unggulan Nasional Informatika dan Komputer, 2(1). http://dx.doi.org/10.0809/seruni.v2i1.583

Susilana, R., \& Riyana, C. (2009). Media Pembelajaran: Hakikat, Pengembangan, Pemanfaatan dan Penilaian. Bandung: Wacana Prima.

Sutedi, D. (2009). Penelitian Pendidikan Bahasa Jepang. Bandung: Humaniora Utama Press.

Thiagarajan, S., Semmel, D., \& Semmel, M. (1974). Instructional Development for Training teacher of Exceptional Children. Indiana: ERIC.

Yamasari, Y. (2010, Agustus). Pengembangan media pembelajaran matematika berbasis ICT yang berkualitas. Seminar Nasional Pascasarjana X-ITS, Surabaya. Diakses dari https://mathmagicedu.wordpress.com/2018/03/15/ pengembangan-media-pembelajaran-matematikaberbasis-ict-yang-berkualitas/. 


\title{
JAPANEDU: Jurnal Pendidikan dan Pengajaran Bahasa Jepang http://ejournal.upi.edu/index.php/japanedu/index
}

\section{Speech Act Realization on Handbook Mitigation Disaster in Japan}

\author{
Rd. Januar Radhiya ${ }^{1,2}$, Asteria Permata Martawijaya ${ }^{1}$ \\ ${ }^{1}$ Program Studi Bahasa Jepang, STBA YAPARI-ABA Bandung, Bandung, Indonesia \\ ${ }^{2}$ Faculty of Policy Studies, Chou University, Tokyo, Japan \\ rjradhiya@stba.ac.id
}

\begin{abstract}
A B S T R A C T
This study investigates speech act strategies used in earthquake mitigation handbooks in Japan, and focuses on finding the type of communicative functions of the speech act strategies used. The government of Japan has provided online and printed handbooks for the people, to reduce risks to a minimum level regarding the disaster so people can prepare beforehand. The data in this study were collected from online leaflet and handbook regarding earthquake mitigation provided by 9 government city's websites, the Ministry of Foreign Affairs of Japan, and by collecting actual handbook and leaflets from Indonesian lives in Japan. The data were analysed using descriptive qualitative method. Collected data then categorized into assertive and directive speech acts, negative and positive politeness based on Brown and Levinson's politeness theory, and focusing on expression of consideration (hairyo hyougen). This study found that there are 659 statements related to earthquake disaster mitigation collected from the data. Also, the findings showed that there are 179 assertive and 480 directives speech acts, with more of imperative directive speech than prohibition directive speech. Moreover, Japanese government tend to use hairyou hyougen on their leaflet and handbook disaster mitigation to show respect to the reader.
\end{abstract}

K E Y W O R D S

Disaster mitigation; Earthquake; Hairyou hyougen; Japanese; Speech act

$\begin{array}{lcc}\text { A R T I C L E } & \text { I N F O } \\ \text { First received: } 16 \text { April 2020 } & \text { Final proof accepted: } 11 \text { June } 2020\end{array}$

\section{INTRODUCTION}

Japan lies between the four world plates and the Pacific Ring of Fire. The plates form 80 percent of the Japan's land, which are also volcanoes. The movement of the earth's plates in the Pacific Ring of Fire area makes Japan frequently having earthquakes and tsunamis. Therefore, disaster response education in Japan has been taught since primary school. Disaster response training is also carried out periodically in schools, offices and even in rural areas. The city and regional governments make this manual and guidelines for disaster mitigation education and information that is sustainable. It makes Japanese people sensitive to the threat of disasters and ready to face disasters that may happen. Advance technology and systems support also established in Japan as 
disaster response information. Every time a disaster happens in Japan, the notification of disaster can be directly accessed by the Japanese people through the device they use, such as smartphone, tablets, etc. The Japanese government provides information on disaster mitigation. This information is given free to the public in the form of leaflets, handbooks, and checklist directly or through the website.

Japan has good preparedness in disaster mitigation in Japan. It can be seen from the number of counselings about disaster preparedness, the use of technology and technological development in predicting and making disaster warnings, evacuation drills in order to deal with disasters, and leaflets about disaster preparedness with unique and interesting writing and design.

According to the Law Number 24 of 2007, Chapter I General Provisions, Article 1 number 9 and the Governemnt Regulation Number 21 of 2008, Chapter I General Provisions, Article 1 number 6 , mitigation means an effort that aims to reduce the impact of disasters. It is a series of efforts to reduce disaster risk, both through physical development and awareness and increase ability to face the threat of disaster.

The Japanese government made a scheme for sustainable mitigation of natural disasters using leaflets or handbooks as a form of sustainable mitigation in dealing with natural disasters. They are needed as written information that are easily stored to remind people about disaster preparedness. As an initial hypothesis, efforts to increase awareness and increase the ability to deal with disaster threats can be done by distributing leaflets and handbooks. In addition, Japanese culture highly respects the feelings of the interlocutors and expressions of attention to the face of the speech partner (hairyo hyougen) to create good communication (Radhia, 2013). That way, the community will feel comfortable when reading and paying attention to the contents of the leaflet/ handbook.

According to Pen (2005), hairyo hyougen in communication is used based on two important factors in the expression used, which are: 「相手 の心が傷つかない」 (aite no kokoro ga kizutsukanai) means 'not hurting the feelings of the speech partner', and 「相手に好ましい印象を与える」 (aite ni konomashii inshou o ataeru) which means 'gives a good impression to the speech partner'.
This expression of hairyo hyougen by Pen (2005) is divided into four types, each of which has a method and strategy for its formation:

(1) Kanwa Hyougen (gentle expression),

(2) Jueki Hyougen (expression of receiving kindness),

(3) Purasu Kachi Fuka Hyougen (Expression to add a positive value). What is meant by this expression is the use of expressions that try to show a good image to the speech partner.

(4) Kokochi Yoi Hyougen (Pleasing expression). What is meant by this expression is, an expression that makes the feelings of the speech partner comfortable, does not interfere with the comfort of the speech partner or an expression that can melt the tense feelings of the speech partner.

The use of leaflets/handbooks as an effort of mitigation of natural disasters considers it as one of the written information and easily stored for disaster preparedness. With leaflets, efforts can be made to increase awareness and increase capacity to face the threat of disaster. Japanese culture highly respects the feelings of the interlocutors and expressions of consideration/attention to the face of the speech partner (hairyou hyougen), which aims to create good communication. That way the community will feel comfortable when reading and paying attention to the contents of the leaflet.

Leaflets are one form of speech is written and installed in public area. There are sentences such as declarative, suggestions, commands, prohibitions, etc. The written sentences can become speech acts that are made with certain strategies and politeness. This statement is supported by Leech (1993) who declared that speech acts consider five aspects of the speech situation, including (1) the speaker and the speech partner; (2) speech context; (3) the purpose of speech; (4) speech act as an action; and (5) speech as a verbal act.

The producers of the leaflets can be considered as speakers, and the reader is the hearer. Every sentence written in the appeal (written medium) is utterance. Speech has a specific purpose and takes place in a context that binds and underlies the speech. Based on this explanation, the speech strategy and politeness of an appeal can be seen from the written sentence by referring to the speech act theory. Speeches in leaflets distributed in public places have a certain function and purpose to produce influence on the reader and listener. 
Speech acts research in writing has been widely researched. Pratiwi, Kristianto, and Carniasih (2018), Riyadi (2019), and Windiatmoko (2019) examine speech acts in writing that can be read by the public like tourism brochure, advertising banner and election banner. The speech act that they found on the data is that it uses commissure speech act such as promises, directive speech acts such as commanding, requesting, and prohibiting, and assertive speech acts strategies such as stating, notifying, etc. In addition, sometimes, acts of gratitude that are included in the expressive speech act category are found. The imperative meaning of the appeal in the research was analyzed with politeness such as Brown and Levinson (1987) theory as well as the principle of cooperation between Grice (1989) and Leech (1983). In previous studies the use of directive speech acts is more widely used in the realization of speech strategies contained in writing (appeal).

Researches on speech acts on the appeal or announcement above discusses the speech acts of written language in announcements or appeals posted in public places about environmental conservation activities or efforts. However, this study is different. The difference is in the data source that will be used as research material which are Japanese-language leaflets for disaster mitigation. The focus of this research is also different, which focuses on Japanese government's speech acts in the disaster mitigation leaflet delivered to the public. This study also analyze strategies in written form that strongly consider readers' taste in disaster mitigation leaflets. In this study the discussion focuses on speech strategies and politeness of language related to hairyou hyougen in the disaster mitigation leaflets. The results can be used as reference material in making perfect leaflets based on examples of speech act strategies that are found with language curiosity in disaster mitigation. So the novelty in this study is the speech act strategy, politeness and taste balance expression in the disaster mitigation leaflet.

Therefore, it helps us to learn how the Japanese convey disaster mitigation information in leaflets about disaster preparedness, as well as strategies in conveying information in the leaflet in linguistic and speech acts. This study aims to identify the realization of Japanese speech and politeness strategies in leaflets/handbooks as a form of disaster mitigation in Japan. This study discusses two things, namely the realization of the speech strategy in the leaflet and the politeness of the Japanese language contained in the leaflet.

\section{RESEARCH METHOD}

The method of the study is descriptive qualitative. A descriptive qualitative was used in this study because it suitable for this theme of the research and data of this research is textual data.

This study used an instrument in the form of a study sheet on the use of language in disaster mitigation leaflets in Japan. The data was collected from nine cities in nine areas in Japan. In nine handbooks or leaflets, the data were classified based on preparations for dealing with earthquake disasters, when there is an earthquake and postearthquake disaster.

The handbooks were obtained online through the city's website of 9 regions of Japan. The 9 regions were Hokkaidou-Sapporo, TouhokuIwate, Kantou-Tokyo, Chuubu-Shizuoka, KinnkiOsaka, Chuugoku-Hiroshima, Shikoku-Kagawa, Kyuushuu-Fukuoka, and Okinawa.

The steps in analyzing the data started by collecting handbook and leaflet about mitigation disaster from 9 areas to know the forms of speech and written language. The data then identified and classified, and then calculated based on the speech act strategies types based on theories used in this study. Lastly, conclusion were drawn based on the existing data and analysis.

\section{FINDINGS AND DISCUSSION}

The data consisted of examples of leaflets/ handbooks containing information on natural disaster migrations that are made and distributed in Japan. This study grouped them into several categories of regions using leaflets and then analyzed the speech acts used based on the theory of Searle (2005)'s speech acts, Brown \& Levinson (1987)'s politeness, and Pen (2005)'s hairyou hyougen.

From 9 handbooks/leaflets, there were 659 data found. The data were categorized based on earthquake preparedness, when an earthquake occurs and after an earthquake occurs. In the leaflet when there is an earthquake there are several places such as home, apartments, tall buildings, in crowded places, in shops and even the ground. 


\section{Speech Acts in Leaflets/Handbook of Natural Disaster Mitigation in Japan}

From the data, there are types of speech acts namely assertive and directive speech acts, that appeared in earthquake disaster mitigation in 9 cities in 9 regions in Japan in preparation situations.

\section{Assertive Speech Acts with Illocution Stating Information}

The data contains 179 assertive speech acts with the illocutionary-meaning stating information. In situations of preparation for facing disasters, the data includes following examples.

(1) 震度 6 弱 立っているのが困難になる。 Shindo 6 yowa tatteiru no ga konnan ni naru. Seismic intensity less than 6 makes it difficult to stand.

(2) 地下鉄は比較的安全と言われている。 Chikatetsu wa hinkakuteki anzen to iwareteiru. The subway is relatively safe.

(3) 高層階では、摇れが数分続くことがある。 Kousokai dewa, taore ga suufun tsudukukoto ga aru. On higher floors, shaking may last for several minutes.

(4) 家の周囲の安全対策。

Ie no shui no anzen taisaku.

Safety measures around the house.

In preparing for an earthquake, the handbook/leaflet of mitigation in Japan contains important information about disaster preparedness such as: (1) It states that when an earthquake is on 6 Richter scale, people will have difficulty standing up, (2) Information about being safer on the ground than to stand on the surface, (3) A high building will shake sometime after the earthquake, and (4) Statements about making mitigation plans in their own families.

When a disaster occurs, the assertive type of speech with illocution states the information as follows.

(5) わが家でも、オフィスでも、基本的な心得は 同じです。

Wa ga ie demo, ofisu demo, kihontekina kokoroe wa onajidesu.

The basics are the same whether you are at home or in the office.
(6) 地震でドアや空 が変形すると開かなくなる可 能性があります。

Jishin de doa ya mado ga henkei suru to akanakunaru kanosei ga arimasu.

If the door or window is deformed due to an earthquake, it may not open.

(7) 急ブレーキは事故の原因となります。 Kyuu bure-ki wa jikou no genin to narimasu. Sudden braking may cause an accident.

(8) 落ち着いて、冷静に行動することが脱出のポ イントです。

Ochitsuite, reisei ni koudou suru kotoga dasshutsu no pointo desu.

Being calm and acting calmly is the key to escape.

When an earthquake happens, they state that no matter where you are, the risk of an earthquake disaster is the same. Statement (6) states there is a possibility that doors and windows will move and cannot be opened due to an earthquake. When there is an earthquake on the road, statement (7) provide information one of the causes of traffic accidents that occur is to brake suddenly. According to statement (8), the importance of knowing to acting calm is the best thing.

The local government conveys many information conveyed by using the illocution states (assertive).

(9) 家の内外は、割れたガラスなどで危険です。 Ie no naigai wa, wareta garasu nado de kiken desu. Broken glass inside and outside the house is dangerous.

(10)あなただけでなく周りも全員被災者です。 Anata dake denaku mawarimo zen'in hisaisha desu. Not only you but everyone around you is a victim.

(11)正しい情報 確かな行動。

Tadashii jouhou tashika na koudou.

Correct information Certain actions.

(12)しばらくはごみの回収はできません。 Shibaraku wa gomi no kaishuu wa dekimasen. Garbage cannot be collected for a while.

Statement (9) informs about the dangers of broken glass inside and outside the house. Statement (10) stated that during an earthquake, all people affected by the earthquake and everyone is victims. Statement (11) inform that to get the correct information and take a certain action. 
Statement (12) stated that the collection of waste will not be conducted during earthquake disaster.

The illocutions are found in many preparations during and after disasters.

\section{Directive Speech}

From the data, 480 speech acts with the meaning of directive illocution found. Including the strategy of indirect imperative, direct rule, prohibition, and questions.

It can be seen from Table 1 that the directive speech were dominated by the meaning of commanding. To reduce the risk of disaster, it must be firmly conveyed or ordered.

Table 1: Number of illocutionary meanings in directives.

\begin{tabular}{|c|l|c|}
\hline No & \multicolumn{1}{|c|}{ Illocutions } & Speeches \\
\hline 1 & Imperative & 426 \\
\hline 2 & Interrogative & 13 \\
\hline 3 & Prohibition & 41 \\
\hline & Total & $\mathbf{4 8 0}$ \\
\hline
\end{tabular}

\section{Direct Imperatives}

From the data, the direct speech command strategies were also found. In Japanese sentences, the form of direct command is often using the form of te kudasai or uses an exclamation mark.

（13）徹底したごみの少量化と 分別を行ってくだ さい。

Tetteishita gomi no shouryouka to bunbetsu o itte kudasai.

Thoroughly reduce the amount of waste and separate it.

(14) テーブルなど頑丈なものの下で、身体の安 全を確保してください。

Te-buru nado kanjouna mono no shita de, shintai no anzen o kakuhoshite.

Keep yourself safe under a sturdy object such as a table.

（15）地震火災を防ぐ!

Jishin kasai o fusegu!

Prevent earthquake fire!

Data (13) and (14) are direct imperatives with the form te kudasai. Statement (13) orders to separate waste, while statement (14) orders to save themself by hiding under the table when an earthquake occurred, and (15) is an order to prevent earthquake fire.

\section{Indirect Imperratives}

In addition, there are also indirect imperatives found as directive utterances, including the following examples.

（16）地震が発生したときには、あわてず落ち着 いて、身を守る行動をしましょう。

Jishin ga hasseishita toki niwa awatezu ochituite, shin o mamoru koudou o shimashou.

When an earthquake occurs, stay calm and take actions to protect yourself.

（17）運転中は、ゆっくり減速し道路の左側に駐 車しましょう。

Untenchuu wa, yukkuri heisoushi dourou no migi gawa ni shuusha shimashou.

Slow down slowly and park on the left side of the road while driving.

(18) 可能であれば、空やドアを開けて出口を確 保する。

Kanoudeareba, mado ya doa wo akete deguchi o kakuho suru.

If possible, open windows and doors to secure exits.

(19) 先生や校内放送の指示に従う。

Sensei ya kounai housou no shiji ni shitagau.

Follow instructions from teachers and school broadcasts.

Statement (16) and (17) are indirect imperatives because they use the mashou form. In ordinary situations, its function is to invite. In the leaflets or handbooks, it becomes indirect imperative to reduce disaster risk. Statement (18) and (19) used narrative form instead of ordering, but if we look at the illocutionary meaning of the two utterances, it instructs readers to secure a way out and follow teacher's direction.

\section{Interrogatives}

There are also direct interrogatives that use question marks and the particle $-k a$ at the end of the sentence as follows.

(20) 地震 だ ! そのときどうする ? Jishin da! Sono toki dousuru? An earthquake! What would you do then?

(21) 避難時の服装はどうするか。 Hinan toki no fukusou wa dousuruka? What to do when evacuating? 
(22) 家族は大丈夫か

Kazoku wa daijoubuka?

Are your family okay?

(23) 地震って何?

Jishintte nani?

What is an earthquake?

Data (20) and (23) show that the question mark is used to ask questions and what to do. While data (21) and (22) used particle $-k a$ to ask.

\section{Direct and Indirect Prohibition}

The leaflets and handbooks also contain the speech of prohibitions. Indirect prohibition is the most common type. The data include the following examples.

（24）ビルなどの頑丈な建物 の中にいる場合は、 あわてて外に出ない。

Biru nado no kanjona tatemono no nakani iru baaiwa, awatete soto ni denai.

If you are inside a sturdy building, do not rush out.

(25) 門や塀には近寄らない。 Mon ya hei niwa chikayoranai.

Stay away from gates and fences.

(26) 勝手に車外一出るのは危険。

Katte ni shagai e deru no wa kiken

It is dangerous to get out of the car in rush.

(27) 火に近づくな。

Hi ni chikadzukuna.

Don't approach the fire.

Data (24) and (25) contain negative form of sentence, which forbid to carry out an activity that is considered life-threatening. Number (26) does not use the negative form but the word kiken means dangerous to get out when an earthquake occurs when you were on a vehicle. Number (27) uses the dictionary form $n a$ to prohibit directly.

\section{Politeness in Leaflets/Handbook of Natural Disaster Mitigation in Japan}

This study use Brown \& Levinson (1987)'s politeness theory with the expression of consideration (hairyo hyougen).

There are 3 categories of politeness in the speech acts. They are bald on-record (395 data), negative politeness (100 data), and positive politeness (162 data).
The following are the examples of bald onrecord.

(28) 固定していない家具のほとんどが移動した り倒れる。

Koteishite inai kagu no hotondo ga idoushitari taoreru.

Most unfixed furniture moves or falls.

（29）公園などの広い場所、丈夫な建物の中など に避難する。

Kouen nado no hiroibasho, joubu na tatemono no naka nadoni hinan suru.

Evacuate in a large area such as a park or in a sturdy building.

(30) 津波から避難。

Tsunami nara hinan.

Evacuation from tsunami.

(31) エスカレーター、エレベーターは利用しな い。

Esukare-ta, erebe-ta- wa riryoushinai.

Do not use escalator or elevator.

Data (28), (29), (30), and (31) show that the information content is important and there is no further ado when delivering it. Preparation and knowledge about earthquakes is important.

\section{Positive Politeness Strategies}

This strategy is used to show intimacy to the speech partner. To facilitate interaction, the government tries to give the impression of being in the same boat as the speech partner (community). This strategy is used to protect the partners' (or readers') positive face, and to reflect government's solidarity and effort to emphasis togetherness as they all in the same condition.

The following are the examples of positive politeness strategy found from the data.

(32) 家族や近所に知らせて、落ち着いて初期消 火しましょう。

Kazoku ya kinjou ni shirasete, ochitsuite shokishouka shimashou.

Let your family and neighbors know and calm down the fire.

(33) まずはあわてず落ち着きましょう。 Mazu wa awatezu ochitsuite kimashou. Let's calm down first. 
（34）ドアや空を開けて非常口を確保しましょ う。

Doa ya mado wo akete hijouguchi wo kakuhoushimashou.

Open the doors and windows to secure the emergency exit.

There is mashou behind the sentence to smooth the form of the command. So they use the form of inviting whereas it means governing to calm down and secure a way out when an earthquake occurs.

\section{Negative Politeness Strategies}

Negative politeness strategy is an action taken to redeem the negative face of the speech partner and the desire of the speaker to be free from the burden with the intention that the actions and intent are not disturbed and not constrained. This action is nothing but the basis of valuing behavior, which is also found in positive politeness strategies.

The difference is that this strategy is more specific and more focused because the speaker displays support functions to minimize certain burdens as something that cannot be avoided by the interlocutor. The main focus of using this strategy is to assume that the speaker is most likely to put the burden or disturbance on the speaker because he has entered the opposite speaker area. It is assumed that there are certain social distances or certain obstacles in the situation.

(35) マンション特有の被害はマンション防災パ ンフレットをご覧ください。

Mashon tokuyu no higai wa mashon bosai panpuretto o goran kudasai.

For damages specific to condominiums, please see the condominium disaster prevention brochure.

(36) みんなが被災者という状況で、地域で協力 しながら不自由な生活を乗り越えなければ なりません。

Minna ga bousaisha to iu joukyou de, chiiki de kyouryoku shinagara fujiyuu na seikatsu o norikoenakerebanarimasen.

We must overcome the inconvenient life by cooperating in the community in the situation that everyone is a victim.

(37) 子どもやお年寄りの話し相手や手伝いなど も立派な支援です。

Kodomo ya otoshiyori no hanashiaite ya tetsudai nadomo rippana shien desu.

Children and elderly people also have great support from talking to people and helping.
(38) 車、オートバイ、自転車などの使用は大変 危険で、緊急車両通行の妨げにもなります。 Kuruma, o-tobai, jitensha nado shiyou wa taihen kikende, kinkyuusharyoutsuukou no samatage nimo narimasu.

The use of cars, motorcycles, bicycles, etc. is very dangerous and may obstruct the passage of emergency vehicles.

(39) 絶対に裸足では歩き回らないようにし、必 ずスリッパなどを履いてください。

Zettai ni rasoku dewa arukimawaranai younishi, kanarazu surippa nado o kutsuite kudasai.

Never walk around barefoot, and always wear slippers.

Data (35) used the form of delivering information to read and pay attention to disaster mitigation in the apartment building. This data implies that readers who are dated in the apartment prepare themselves and know the handling of the earthquake disaster. Politeness used is negative politeness shown by the absence of coercion from the speaker to read or follow the mitigation written on the handbook. Data (36) and (37) asked the readers to work together in order to get through the post disaster situation together with examples of activities is to invite to chat and pay attention to each other especially for children and parents. In this speech comes a negative politeness because it has asked people to do what is appealed to the appeal that was disseminated.

Data (38) is negative politeness because it asks people not to use cars, motorbikes or bicycles for personal gain because it will interfere with disaster emergency cars. The government indirectly prohibits using private vehicles. Requests to speech partners will certainly slightly tarnish the face of the speech partners.

Data (39) used a straightforward politeness strategy with negative politeness. The word zettai and te kudasai form characterize the use of negative politeness in this speech. Speakers in this case the government asks the people not to walk or walk around without sandals even though they are at home because there are many broken glasses that endangers the community.

\section{Hairyo Hyougen}

From the data, it was found that there are only three types of hairyo hyougen used. They are kanwa hyougen, purasu kachi fuka hyougen, and kokochi yoi hyougen. 


\section{Kanwa Hyougen}

In this softening expression, most of the data that uses the form of noise and change certain vocabulary into this category.

(40) 強い摇れが来る前に、テレビ、ラジオなど で地震をお伝えします。

Yowai yure ga kuru maeni, terebi, rajio nado de jishin wo otsutaemasu.

We will inform you of the earthquake on TV, radio, etc. before the strong shaking comes.

(41) 家屋の耐震診断を受け、必要な補強をして おく。

Kaoku no taishin shindan o uke, hitsuyouna houkyo shite oku.

Receive the earthquake resistance diagnosis of the house and make necessary reinforcements.

(42) 被災後の生活はどうなるか。

Hisai ato no seikatsu wa dounaruka.

What will happen to life after the disaster?

In data (40), masu form was used to give a soft impression on the statement, as well as data (41) which use te oku to soften the statement, while data (42) used question form to soften statement.

\section{Purasu Kachi Fuka Hyougen}

This expression adds a sense of calm and courtesy to the speech. The following are the examples.

(43) 家にいる家族の 安否を確認しましょう。 Ie ni iru Kazoku no anbi o kakunin shimashou. Check the safety of your family at home.

(44) 協力して消火活動を行いましょう。 Kyouryokushite shouka katsudou wo okonaimashou. Let's cooperate in fire fighting.

Data (43) and (44) used mashou as indirect requests or orders. They can have subtle meanings as order and add familiarity.

\section{Kokochi Yo Hyougen}

The utterance is to calm readers. In this study, the data also contain some expressions that can calm readers. The examples are as follows.

(45) みんなが被災者という状況で、地域で協力 しながら不自由な生活を乗り越えなければ なりません。
Minna ga hisaisha to iu joukyoude, chiiki de kyouryoku shinagara fujiyuu na seikatsu o norikaenakereba narimasen.

In the situation that everyone is a victim, we must overcome the inconvenient life while cooperating in the area.

(46) 助け合いの心が大切。壊れた家には入らな い。

Tsukeai no kokoro ga taisetsu. Kowareta ie niwa hairanai.

It is important to help each other. And don't enter a broken house.

(47) 可能なら駐車場等一移動・駐車する。 Kanou nara shuushajou tou e idou- chuusha suru. Move/park to a parking lot if possible.

Data (45) and (46) emphasizes the importance to help each other during disaster to give sense of peace to the readers. Data (47) used the word kanou that is a possibility to calm the readers as well.

In term of politeness, the leaflets and handbooks will not be inversely proportional to the politeness of Brown and Levinson. The data analysis mainly conducted based on Searle (2005) theory by classifying the data into directive speech with an imperative strategy. This shows that speech acts on disaster mitigation materials such as handbook/leaflet considering the readers' feelings by using expression of consideration (hairyou hyougen) (Pen, 2005) with 395 politeness bald onrecord, 162 positive politeness strategies, and 100 negative politeness strategies.

From the data and analysis it can be seen the difference between bald on-record and positive politeness strategies which used more frequently than negative politeness strategies. This means that statements in this disaster mitigation handbook takes the feelings of the reader into consideration by using hairyou hyougen.

\section{CONCLUSION}

This study concludes that Japanese culture, as a culture with indirect communication, disguises commands in every writing or utterance in the disaster mitigation leaflets and handbooks. The findings showed that speech acts found from the data were directives imperatives with 426 statements. Therefore, readers or interlocutors do not feel to be patronized or ordered to do something directly. The data also showed that the government give a high consideration on how the 
readers feel when they read the handbook or leaflet disaster mitigation especially earthquake.

\section{ACKNOWLEDGEMENT}

This research was funded by a grant from the Ministry of Research, Technology and Higher Education through LLDIKTI Region IV with the Beginner Lecturer Research program for a period of one year, taking Japanese language specialties and disaster mitigation.

\section{REFERENCES}

Brown, P. \& Levinson, S.C. (1987). Politeness Some Universals in Language Usage. New York: Cambridge University Press.

Grice, H. P. (1989). Studies in the Way of Words. Cambridge, MA: Harvard University Press.

Law of The Republic of Indonesia Number 24 of 2007 Concerning Disaster Management.

Leech, G. (1993). Prinsip-prinsip pragmatik. (M.D.D. Oka, Trans.). Jakarta: Universitas Indonesia Press.

Pen, F. (2005). Nihongo no "Hairyo Hyougen" ni Kansuru Kenkyuu -Chungokugo to no Hikaku Kenkyuu ni Okeru Shomondai -. Tokyo: Izumi Shoin.

Pratiwi, N. M. S., Kristianto, Y., \& Carniasih, N. P. S. E. (2019). The directive illocutionary acts in imperative sentences on the tourism attraction brochures. Litera: Jurnal Litera Bahasa Dan Sastra, 4(1), 13-21. Retrieved from https://jurnal.undhirabali.ac.id/index.php/litera/a rticle/download/592/519

Radhia, E. (2013). Strategi menyampaikan keinginan dalam bahasa Jepang: Kajian hairyo hyougen. Jurnal Arbiter, 1(1), 75-87. https://doi.org/10.25077/ar.1.1.75-87.2013

Riyadi, S. (2019). Jenis tindak tutur ilokusi dan implikaturnya dalam banner calon legislatif pemilu 2019. Literasi: Jurnal Penelitian, Pendidikan Bahasa, dan Sastra, 2(02), 29-42. Retrieved from http://jkqh.uniqhba.ac.id/index.php/literasi/articl e/download/90/50/

Searle, J. R. (2005). Expression and Meaning; Studies in The Theory of Speech Acts. Cambridge: Cambridge University Press.

Windiatmoko, D. U. (2018). Kajian pragmatik pada banner "Pitik cilik: beli dada gratis paha". Proceeding of SNP2M (Seminar Nasional Penelitian dan Pengabdian Masyarakat) UNIM (pp. 182-186). Mojokerto: Universitas Islam Majapahit. 


\title{
Chuugi Bushido Value in Animation Movie "Sengoku Musou" by Kojin Ochi
}

\author{
Ruditya Yogi Wardana, Ely Triasih Rahayu, Dian Bayu Firmansyah ${ }^{*}$, Hartati \\ Program Studi Sastra Jepang, Universitas Jenderal Soedirman, Purwokerto, Indonesia \\ *dbayuf@unsoed.ac.id
}

\begin{abstract}
A B S T R A C T
This research was based on one of the most popular Japanese cultural value called Bushido, especially chungi value in Sengoku Musou animated film by Kojin Ochi. The purposes of this research were: 1) Describing the implementation of chuugi value in bushido, 2) Describing the act of chuugi, and 3) Describing the act that deviate from chuugi. The method used in this research was a qualitative research method. The results of this study showed that there were 20 acts of chungi and 5 acts that deviate from chuugi in Sengoku Musou animated film. Moreover, this research indicated that the act of chuugi can be motivated by several factors such as the aspect of obedience with orders, the desire to stay together, and the will to sacrifice everything for their master. On the other hand, the deviation of chungi were occurred because of economic factor, depression factor, psychopathic factor, seeking a target for disappointment factor, and opposing social bonding factor.
\end{abstract}

\begin{tabular}{ll}
\hline K E Y W O R D S \\
\hline Bushido; Chuugi; Konsep perilaku; Sengoku Musou
\end{tabular}

First received: 12 February 2020

Available online: 20 June 2020

\section{PENDAHULUAN}

Budaya berasal dari bahasa Sansakerta budhayah yang merupakan bentuk jamak dari budhi yang memiliki arti budi atau akal manusia, sehingga budaya dapat diartikan segala hal yang berkaitan dengan akal manusia (Widyosiswoyo, 2004). Budaya sendiri merupakan suatu cara hidup yang berkembang dan dimiliki bersama oleh kelompok masyarakat/bangsa dan diwariskan dari generasi ke generasi. Budaya terbentuk oleh gagasan manusia yang meliputi unsur yang rumit yaitu pemahaman perasaan suatu bangsa yang kompleks, sistem agama, adat istiadat, karya seni, hukum, moral, dst. (Taylor dalam Sulaeman, 1998).

Budaya memiliki beberapa unsur abstrak, salah satunya merupakan nilai-nilai dari budaya. Nilai dari suatu budaya memiliki fungsi sebagai pedoman terhadap tindakan manusia (Koentjaraningrat dalam Sulaeman, 1998). Nilai dari suatu budaya mengakar kuat pada jiwa suatu masyarakat, sehingga suatu budaya dapat mencerminkan jati diri suatu masyarakat. Seperti di Indonesia terdapat salah satu budaya yaitu guyub rukun dan salah satu nilai yang terkandung di dalamnya yaitu gotong royong. Nilai tersebut dapat terlihat pada kegiatan masyarakat seperti 
kerja bakti di lingkungan tinggal. Berbeda dengan Indonesia, masyarakat di Jepang memiliki nilai budayanya sendiri. Salah satu contohnya tercermin pada sikap para samurai pada era Sengoku.

Era Sengoku merupakan satu era di mana terjadi konflik militer di negara Jepang. Era Sengoku dimulai pada sekitar tahun 1467 sampai sekitar tahun 1615. Perang Ōnin pada tahun 1467 merupakan titik permulaan dari era Sengoku yang memiliki tujuan untuk menggulingkan pemerintahan shogun Ashikaga. Kemudian era Sengoku diakhiri pada peristiwa pendudukan kastil Osaka oleh Tokugawa Ieyasu yang memiliki tujuan untuk meruntuhkan klan Toyotomi. Pada masa ini, samurai mengamalkan nilai-nilai bushido terutama nilai kesetiaan terhadap pemimpin. Para samurai pada masa ini bersumpah setia untuk mengikuti pemimpinnya. Hal tersebut sesuai dengan nilai chuugi yang terkandung dalam konsep bushido.

Bushido berasal dari tiga kanji yaitu kanji $B u$ (武 ) yang berarti militer, Shi (士) yang berarti kesatria, dan Dou (道) yang berarti jalan. Secara harafiah, bushido memiliki arti 'jalan kesatria'. Konsep bushido dipengaruhi oleh tiga ajaran yaitu ajaran Konfusius, Zen Buddhisme, dan Shintoisme. Ketiga ajaran tersebut melahirkan konsep bushido yang mengandung tujuh nilai, yaitu $g i$ (kebenaran), $y u$ (keberanian), jin (kebajikan), rei (hormat/sopan santun), makoto/shin (kejujuran), meiyo (harga diri), dan chuugi (loyalitas).

Nilai-nilai bushido tercerminkan pada salah satu film yaitu Sengoku Musou karya Kojin Ochi. Salah satu nilai bushido yang tercermin pada film ini adalah chungi (loyalitas) yang terlihat pada saat Hideyoshi mengatakan kalimat terakhirnya kepada jenderal terpercayanya, Ieyasu dan Mitsunari. Seperti dalam dialog (1):

\begin{tabular}{|c|c|}
\hline (Dialog 1) & \\
\hline 家康 & : 豊臣どの \\
\hline Ieyasu & $\begin{array}{l}\text { : Hideyoshi-dono } \\
\text { 'tuan Hideyoshi' }\end{array}$ \\
\hline 秀吉 & $\begin{array}{l}\text { : 豊臣の事...わが子、秀頼の事 } \ldots く \\
\text { れぐれを ...くれぐれを }\end{array}$ \\
\hline Hideyoshi & $\begin{array}{l}\text { :Toyotomi no koto... waga ko, Hideyori } \\
\text { no koto... kure gure o... kure gure o } \\
\text { 'tolong jaga... klan Toyotomi... dan } \\
\text { juga putraku, Hideyori...' }\end{array}$ \\
\hline & : お任せあれ \\
\hline Ieyasu & $: \frac{\text { Omakase are }}{\text { 'serahkan pada saya.' }}$ \\
\hline
\end{tabular}

$\begin{array}{ll}\text { 三成 } & \text { : 豊臣の家は必ずお守りします } \\ \text { Mitsunari } & \text { :Toyotomi no ie wa kanarazu } \\ & \frac{\text { omamorishimasu }}{\text { 'saya akan melindungi klan }} \\ & \underline{\text { Toyotomi.’ }}\end{array}$

(Sengoku Musou, episode 2, menit 02:40-02:05)

Pada potongan dialog (1) diceritakan Hideyoshi selaku pimpinan tertinggi klan Toyotomi meminta kedua panglimanya, Ieyasu dan Mitsunari untuk menjaga klan Toyotomi dan anaknya yaitu Hideyori. Kemudian disanggupi oleh kedua panglimanya. Dari potongan dialog di atas, sikap yang menunjukkan kesetiaan panglima kepada pemimpinnya yaitu pada jawaban Tokugawa Ieyasu「お任せあれ。」yang berarti "Serahkan pada saya" dan pada jawaban Ishida Mitsunari 「豊臣の家は必ずお守りします。」 yang berarti "Saya akan melindungi klan Toyotomi". Kedua jawaban tersebut menunjukkan nilai loyalitas yang sesuai dengan nilai chuugi.

Selain sikap yang mencerminkan nilai bushido, dalam film ini juga terdapat sikap yang tidak sesuai dengan nilai bushido. Salah satunya merupakan penyimpangan dari nilai chuugi (loyalitas) yang terlihat pada saat Yoshitsugu menjelaskan maksud perintah Mitsunari kepada Kiyomasa dan Masanori untuk pergi ke Kyushu. Seperti dalam dialog (2) berikut.

(Dialog 2)

清正 : おれはお前の命令にはしたがわな い。さらばだ、三成。

Kiyomasa : Ore wa omae no meirei ni wa shitagawanai. Saraba da, Mitsunari. 'aku takkan mau menerima perintah dari orang sepertimu. Selamat tinggal, Mitsunari.'

\begin{tabular}{|c|c|}
\hline 㛝 & : き...清正? \\
\hline & $\begin{array}{l}\text { :Ki... Kiyomasa ? Jyaana. } \\
\text { 'Ki... Kiyomasa? Sampai jumpa.' }\end{array}$ \\
\hline
\end{tabular}

(Sengoku Musou episode 2, menit 09:59-10:08)

Pada potongan dialog (2), Mitsunari selaku panglima dari klan Toyotomi memerintahkan sahabatnya yaitu Kiyomasa dan Masanori untuk pergi menjaga Kyushu. Merasa sikap Mitsunari berubah dan terlihat tidak peduli terhadap klan Toyotomi, Kiyomasa menolak perintah dari Mitsunari diikuti oleh Masanori. Hal tersebut terlihat pada dialog Kiyomasa「おれはお前の命 令にはしたがわない。さらばだ、三成。」 yang 
berarti "Aku takkan mau menerima perintah dari orang sepertimu. Selamat tinggal, Mitsunari", dan pada dialog Masanori 「き...清正? じゃあな。

$」$ yang berarti "Ki...Kiyomasa? Dah." kemudian mereka meninggalkan Mitsunari dan kawankawannya. Sikap tersebut merupakan sikap melawan perintah seorang pemimpin dan sikap tersebut tidak sesuai dengan nilai chuugi.

Berdasarkan kajian dialog (1) dan (2), penulis tertarik untuk mengkaji implementasi dan penyimpangan dari nilai bushido terutama terhadap nilai chuugi. Film yang akan dianalisis yaitu Sengoku Musou karya Kojin Ochi. Penulis memilih Sengoku Musou dikarenakan pada film ini terdapat implementasi dan penyimpangan dari nilai chuugi. Dengan penelitian ini, diharapkan pembaca, khususnya bagi pembelajar kebudayaan Jepang, dapat memahami bahwa selain keberadaan nilai chuugi, terdapat pula penyimpangan dari nilai tersebut.

\section{KAJIAN TEORI}

\section{Budaya}

Menurut ilmu antropologi, kebudayaan merupakan keseluruhan sistem gagasan, tindakan dan hasil karya dari manusia dalam bermasyarakat yang kemudian dijadikan miliknya sendiri dengan proses belajar (Widyosiswoyo, 2004).

Koentjaraningrat menyatakan bahwa budaya merupakan keseluruhan manusia dari kelakuan dan hasil kelakuan yang teratur oleh tata kelakuan yang harus didapatkannya dengan belajar dan yang semuanya tersusun dalam kehidupan masyarakat (dalam Widagdho, 2010). Selain itu Linton menyatakan bahwa budaya merupakan konfigurasi dari tingkah laku dan hasil laku, yang unsur-unsur pembentuknya didukung serta diteruskan oleh anggota masyarakat tertentu (dalam Widagdho, 2010). Sehingga dapat disimpulkan bahwa budaya merupakan segala sesuatu hal yang didasari oleh gagasan, karya, dan hasil karya dari manusia yang diperoleh dari proses belajar di masyarakat dan diturunkan ke anggota masyarakat tertentu.

\section{Konsep Perilaku}

Perilaku apabila dilihat dari segi biologis merupakan suatu bentuk kegiatan atau aktivitas organisme yang bersangkutan. Jadi, perilaku manusia pada hakekatnya merupakan suatu aktivitas pada diri manusia tersebut. Oleh karena itu, perilaku manusia memiliki bentangan yang luas, mencakup berjalan, berbicara, bereaksi, bahkan kegiatan internal, seperti berpikir, persepsi, dan emosi. Jadi secara garis besar, perilaku merupakan apa yang dikerjakan oleh organisme, baik yang dapat diamati secara langsung atau pun yang dapat diamati secara tidak langsung (Notoatmodjo, 1993).

Kemudian menurut Freud (dalam Notoatmodjo, 2010), perilaku dari sudut pandang psikoanalisis dibentuk oleh 3 aspek, yaitu:

(1) Das es (the id), merupakan aspek kepribadian yang berkaitan dengan aspek biologis.

(2) Das ich (the ego), merupakan aspek psikologi kepribadian yang berkaitan dengan realitas (dunia luar).

(3) Das uber ich (the super-ego), merupakan aspek sosiologis kepribadian yang berhubungan dengan nilai-nilai moral.

Dari uraian tersebut, dapat diambil kesimpulan bahwa perilaku merupakan kegiatan dari manusia, seperti berjalan, berpikir, dan seterusnya, yang dikendalikan oleh kepribadiannya. Kepribadian manusia ditentukan oleh prinsip mencari kenikmatan dan menghindari ketidaknikmatan (das es), dan dalam mencapai kenikmatan dan menghindari kenikmatan, disesuaikan dengan kondisi realitas yang ada (das ich), serta dikendalikan oleh norma-norma sosial dan hati nurani manusia (das uber ich).

\section{Bushido}

Agustian (2010) mengungkapkan makna bushido sebagai sikap rela berkorban untuk pemimpin atau negara. Segala aspek kehidupan samurai dikendalikan oleh bushido. Hal utama bagi samurai dalam bushido adalah mereka harus mengembangkan keahlian olah pedang dan berbagai senjata lain, berpakaian dan berprilaku khusus, serta mempersiapkan kematian yang bisa terjadi sewaktu-waktu ketika melayani tuannya. Mereka mengabdikan kesetiaan itu sebagai standar moral tinggi untuk semua tindakan dalam kehidupan.

Bushido sendiri tidak hanya sebagai aturan dan cara berperang. Akan tetapi juga terkandung ajaran-ajaran moral pada bushido. Nitobe menjelaskan, 
"Bushido, then, is the code of moral principles which the knights were required or instructed to observe. It is not a written code; at best it consists of a few maxims handed down from mouth to mouth or coming from the pen of some well-known warrior or savant. More frequently it is a code unuttered and unwritten, possessing all the more the powerful sanction of veritable deed, and of a law written on the fleshly tablets of the heart." (1908:4)

"Bushido, kemudian, merupakan kode prinsipprinsip moral yang ksatria diminta atau diperintahkan untuk diamati. Ini bukan kode tertulis; terdiri dari beberapa pepatah yang diturunkan dari mulut ke mulut atau berasal dari pena dari beberapa pejuang terkenal atau cendekiawan. Lebih tepatnya adalah kode yang tidak ditulis dan tidak tertulis, memiliki semua sanksi yang lebih kuat dari perbuatan yang benar, dan hukum yang tertulis di lubuk hati." (1908:4)

Bushido terbentuk atas pengaruh dari tiga ajaran. Tiga ajaran tersebut yaitu Konfusius, Zen Buddhisme dan Shintoisme. Ketiga ajaran tersebut mempengaruhi munculnya nilai-nilai pada konsep bushido yang berlaku di kalangan samurai. Terdapat tujuh nilai yang terkandung dalam konsep bushido sebagai berikut.

\section{(1) $G i$ (義 - Kebenaran)}

Kebenaran bagaikan tulang yang menopang tubuh. Tanpa tulang, tubuh tidak akan bisa berdiri tegak, bergerak dan berjalan. Tanpa adanya kebenaran, tidak dapat membuat seseorang menjadi sosok seorang samurai. Para samurai selalu mempertahankan etika, moral dan kebenaran. Menurut Nitobe, kebenaran dijelaskan sebagai berikut.

"Rectitude is the power of deciding upon a certain course of conduct in accordance with reason, without wavering; -to die when it's right to die, to strike when it's right to strike is right." (1908: 20)

"Kebenaran adalah kekuatan untuk membuat keputusan tanpa ragu dengan didasarkan alasan-alasan yang kuat dan rasional- untuk mati apabila memang harus mati dan untuk menebas apabila harus menebas." (1908: 20)

(2) Yuu (勇 - Keberanian)

Dengan keberanian, samurai dapat bertahan dari berbagai kesulitan untuk menjaga prinsip kebenaran yang dipercaya dan diyakininya. Keberanian merupakan ciri yang amat melekat pada samurai, dan dengan resiko apapun samurai siap mempertaruhkan nyawanya untuk memperjuangkan prinsip kebenaran yang dipercaya dan diyakininya. Nitobe mengemukakan:

"Courage is doing what is right. To run all kinds of hazards, to jeopardize one's self, to rush into the jaws of death these are too often identified with Valor, and in the profession of arms such rashness of conduct what Shakespeare calls, "valor misbegot" is unjustly applauded; but not so in the Precepts of Knighthood." (1908:25-26)

"Keberanian melakukan apa yang benar. Untuk menjalankan semua jenis bahaya, untuk membahayakan diri sendiri, untuk bergegas menantang maut, ini terlalu sering disebut dengan keberanian, dan perilaku gegabah dalam militer yang Shakespeare sebut sebagai valor misbegot tidak diapresiasi secara adil; tetapi tidak demikian dalam Persepsi Ksatria." (1908:25-26)

\section{(3) $\operatorname{Jin}($ 仁 - Kebajikan)}

Cinta, kebesaran jiwa, kasih sayang kepada sesama manusia, simpati dan rasa iba selalu dikenai sebagai kebajikan mulia dan merupakan sifat luhur yang paling utama diantara sifat-sifat pada jiwa manusia (Nitobe, 1908). Meski berlatih ilmu pedang dan strategi berperang, para samurai harus memiliki sifat mencintai sesama, kasih sayang, dan peduli. Aspek keseimbangan bushido terdiri dari dua aspek yaitu maskulin (yin) yang diwakili oleh gi dan feminim (yan) yang diwakili oleh jin. Apabila penerapan jin bersamaan dengan penerapan gi, samurai bisa meredam sifat sombong dalam dirinya dan keinginan untuk mendominasi orang lain. Kemurahan hati juga ditunjukkan dalam hal memaafkan. Akan tetapi, para samurai harus membatasi perasaan ini agar tak berlebihan yang bisa membuat samurai menjadi lemah. Masamune mengungkapkan dengan pepatah pendek sebagai berikut.

"Rectitude carried to excess hardens into stiffness, Benelovence indulged beyond measure sinks into weakness." (Nitobe, 1908: 37-38)

"Kebenaran mencegah kekejaman yang kaku, kebajikan yang selalu dituruti akan berubah menjadi kelemahan." (Nitobe, 1908: 37-38)

Jin merupakan "Bushi no nasake", seperti yang dijelaskan Nitobe sebagai berikut. 
"Bushi no nasake, the tenderness of a warrior had a sound which appealed at once to whatever was noble in us; not that the mercy of a samurai was generically different from the mercy of any other being, but because it implied mercy where mercy was not a blind impulse, but where it recognized due regard to justice, and where mercy did not remain merely a certain state of mind, but where it was backed with power to save or kill." (Nitobe, 1908: 38)

"Bushi no nasake, kelembutan seorang pejuang memiliki hal yang menarik sekaligus untuk apa pun yang mulia dalam diri kita; bahwa belas kasih seorang samurai secara umum berbeda dari belas kasih makhluk lain, karena ia menyiratkan belas kasih yang bukan sekedar dorongan buta, tetapi ia mengakuinya karena keadilan, dan di mana belas kasih tidak hanya tentang kondisi pikiran, tetapi di mana ia didukung dengan kekuatan untuk menyelamatkan atau membunuh." (Nitobe, 1908: 38)

\section{(4) Rei (礼 - Sopan santun)}

Seorang samurai diharuskan untuk memiliki rasa sopan santun yang tinggi. Karena kesopanan merupakan bentuk penghormatan terhadap perasaan orang lain. Hal tersebut selaras dengan yang dikemukakan Nitobe sebagai berikut.

"Politeness is a poor virtue, if it is actuated only by a fear of offending good taste, whereas it should be the outward manifestation of a sympathetic regard for the feelings of others. It also implies a due regard for the fitness of things, therefore due respect to social positions; for these latter express no plutocratic distinctions, but were originally distinctions for actual merit." (1908: 45-46)

"Sopan santun akan menjadi kebajikan yang buruk, jika hanya digerakkan oleh rasa takut menyinggung perasaan, padahal itu harus menjadi manifestasi luar dari rasa simpati terhadap perasaan orang lain. Ini juga menyiratkan suatu hal yang pantas, oleh karena itu menghormati posisi sosial; karena yang terakhir ini menyatakan tidak ada perbedaan plutokratis, tetapi pada mulanya adalah perbedaan untuk kebajikan yang sebenarnya." (1908: 45-46)

Dalam bentuk tertingginya, sopan santun bisa berubah menjadi kasih sayang. Bahkan dapat menjadi apa yang sudah kita ketahui seperti seorang samurai akan memilih menderita lebih lama dalam hal kebaikan, berperilaku sepantasnya, tidak mudah terprovokasi, dan tidak menampilkan kebencian. Sopan santun sendiri apabila ditelaah kembali, akan memiliki hubungan terhadap tingkah laku seseorang sesuai dengan pangkatnya dalam kemiliteran, di mana seseorang akan menghormati orang yang memiliki pangkat yang lebih tinggi darinya.

(5) Shin (信 - Kejujuran)

Samurai dituntun untuk memegang teguh akan kejujuran. Dalam hal ini, setiap kata dan setiap kalimat yang dikeluarkan oleh seorang samurai harus bernilai sebuah kejujuran dan dapat dipegang perkataannya oleh orang lain. Hal tersebut selaras dengan pernyataan Nitobe sebagai berikut:

"Bushi no ichi gon, word of a samurai or in exact German equivalent ein Rittenvort was sufficient guaranty of the truthfulness of an assertion. His word carried such weight with it that promises were generally made and fulfilled without a written pledge, which would have been deemed quite beneath his dignity. Many thrilling anecdotes were told of those who atoned by death for ni gon a double tongue." (1908: 57)

"Bushi no ichi gon, kata samurai atau dalam bahasa Jerman yaitu ein Rittenvort, cukup menjamin kebenaran suatu pernyataan. Katakatanya membawa beban sedemikian rupa sehingga janji-janji umumnya dibuat dan digenapi tanpa janji tertulis, yang akan dianggap cukup di dalam harga dirinya. Banyak anekdot yang menceritakan tentang mereka yang berlidah ganda atau ni gon harus menghadapi hukuman mati." (1908: 57)

(6) Meiyo (名誉 - Harga diri)

Para samurai selalu menjalankan kode etik bushido dengan konsisten dan tak pernah sekalipun melanggar kode etik tersebut dengan mengambil jalan pintas. Harga diri para samurai mereka jaga sedemikian rupa melalui perilaku terhormat. Cara mereka menjaga harga diri, salah satunya tidak membuang-buang waktu dengan percuma dan tidak berperilaku atau melakukan hal yang tidak berguna. Dalam hal ini Nitobe mengemukakan bahwa:

"The sense of honor, implying a vivid consciousness
of personal dignity and worth, could not fail to
characterize the samurai, born and bred to value the
duties and privileges of their profession. Though the
word ordinarily given nowadays as the translation of 
Honor was not used freely, yet the idea was conveyed by such terms as na (name) men-moku (countenance), guaibun (outside hearing), reminding us respectively of the biblical use of "name", of the evolution of the term "personality" from the Greek mask, and of "fame."” (1908: 65-66)

"Rasa hormat, menyiratkan kesadaran yang jelas tentang martabat dan harga diri, berhasil mengarakterisasi samurai, lahir dan dibesarkan untuk menilai tugas dan hak istimewa dari profesi mereka. Meskipun kata yang biasanya diberikan saat ini sebagai terjemahan "kehormatan" tidak digunakan secara bebas, namun gagasan itu disampaikan dengan istilah seperti na (nama), menmoku (wajah), guaibun (pendengaran luar), mengingatkan kita masingmasing dari penggunaan kata "nama", dari evolusi istilah "kepribadian" menurut istilah Yunani, dan "ketenaran." (1908: 65-66)

Bagi samurai, kehormatan merupakan salah satu hal yang penting. Apabila seorang samurai kehilangan kehormatannya, maka akan meninggalkan luka yang sangat dalam bagi dirinya dan orang-orang terdekatnya. Hal tersebut selaras dengan pernyataan sebagai berikut:

"That samurai was right who refused to compromise his character by a slight humiliation in his youth; "because," he said, "dishonor is like a scar on a tree, which time, instead of effacing, only helps to enlarge." (Nitobe, 1908: 67-68)

"Samurai itu benar yang menolak untuk mengkompromikan karakternya dengan sedikit penghinaan di masa mudanya; "Karena," katanya, "aib itu seperti bekas luka di pohon, di mana waktu, bukan hanya menempel, tetapi membantu memperbesar." (Nitobe, 1908: 6768)

\section{(7) Chuugi(忠義 - Kesetiaan)}

Seorang samurai harus patuh dan setia terhadap seorang pemimpin. Tidak dipungkiri bahwa pada masanya, seorang samurai cenderung akan lebih memilih mengikuti satu orang pemimpin dan tidak berpindah pada yang lainnya. Dalam hal ini Nitobe mengemukakan:

"Other virtues feudal morality shares in common with other systems of ethics, with other classes of people, but this virtue homage and fealty to a superior is its distinctive feature. I am aware that personal fidelity is a moral adhesion existing among all sorts and conditions of men, a gang of pickpockets owe allegiance to a Fagin; but it is only in the code of chivalrous honor that Loyalty assumes paramount importance." (1908: 74)

"Keutamaan lain moralitas feodal berbagi kesamaan dengan sistem etika lainnya, dengan kelas orang lain, tetapi penghormatan, kebajikan, dan kesetiaan kepada atasan adalah ciri khasnya. Saya sadar bahwa kesetiaan pribadi adalah adhesi moral yang ada di antara segala macam dan kondisi manusia, sekelompok pencopet berutang kesetiaan kepada seorang Fagin; tetapi hanya dalam kode kesetiaan yang penting." (1908: 74)

\section{Chuugi}

Chuugi dalam kamus kanji Bahasa Jepang dituliskan dengan kanji 忠義 yang memiliki arti 'kesetiaan'. Kanji chuugi terdiri atas dua kanji, yaitu kanji 忠 (chuu) yang memiliki arti 'setia' serta kanji 義 ( $g i$ ) yang memiliki arti 'kebenaran'. Chuugi dapat diartikan kesetiaan dalam bertugas walaupun nyawa sebagai taruhannya (Agustian, 2010; Seruni, 2018). Nilai chuugi dalam bushido mengatur seorang samurai untuk menjalankan tugasnya yaitu setia terhadap pemimpin/atasannya. Kesetiaan ditunjukkan dengan dedikasi tinggi seseorang dalam melaksanakan tugas. Kesetiaan seorang ksatria tidak hanya saat pemimpinnya dalam keadaan sukses dan berkembang. Bahkan dalam situasi yang tidak diharapkan terjadi, misalnya pimpinan mengalami banyak beban permasalahan, seorang ksatria tetap setia pada pimpinannya dan tidak meninggalkannya. Puncak kehormatan seorang samurai adalah mati dalam menjalankan tugas dan perjuangan (Rahmah, 2018).

Kesetiaan seorang samurai tidak hanya ditujukan pada seorang pimpinan/atasannya saja, karena keluarga yang merupakan elemen terdekat dari seorang samurai pun berhak atas kesetiaanya. Nitobe (1908, dalam Wulandari, 2018) menyebutkan bahwa kesetiaan/Chuugi (忠義) dalam Bushido berpegang teguh bahwa kepentingan keluarga dan anggota-anggotanya merupakan satu kesatuan utuh dan tidak dapat dipisahkan. Kepentingan tersebut diikat dengan rasa kasih sayang yang alami, yang keluar dari hati nurani. Oleh karena itu, samurai mati untuk seseorang yang dicintai, dan bushido harus hidup dan mati untuk negara atau bagi yang memegang kekuasaan secara sah. Ikatan kesetiaan dari tuan yang satu kepada tuan yang lain tanpa 
mengkhianati kedua-duanya. Nitobe menambahkan:

"Griffis (religions of Japan) was quite right in stating that whereas in China Confucian ethics made obedience to parents the primary human duty, in Japan precedence was given to Loyalty. " (1908: 76) "Griffis (agama-agama Jepang) cukup benar dalam menyatakan bahwa etika Konfusius Cina membuat kepatuhan terhadap orang tua sebagai tugas utama manusia, kemudian di Jepang diutamakan kepada Loyalitas" (1908: 76)

Menurut Nitobe, kepatuhan seorang anak kepada orang tuanya dalam paham etika Konfusius Cina memiliki kesamaan dalam konsep chuugi dalam bushido Jepang. Artinya kepatuhan merupakan hal yang penting dalam kesetiaan.

Seorang samurai pun diharuskan untuk mengedepankan kepentingan kelompoknya. Lafayette (dalam Rahayuningtyas, 2016) menyebutkan bahwa prioritas seorang samurai adalah menempatkan kepentingan kelompok, serta tidak membuat keputusan secara individu atau sewenang-wenang, dan mengkonsultasikan segala sesuatu sesuai adat social orang Jepang.

Seorang samurai dituntut untuk mengesampingkan kepentingan pribadinya, sehingga ia harus merelakan segalanya untuk kepentingan pemimpin/atasannya. Dalam hal ini, Nitobe mengatakan:

"If I be loyal, my father must be undone; if I obey my father, my duty to my sovereign must go amiss." (Nitobe, 1908: 80)

"Apabila aku setia, aku harus menghentikan ayahku; apabila aku menuruti ayahku, aku tidak melaksanakan tugas dari tuanku dengan benar" (Nitobe, 1908:80)

\section{Faktor Penyebab Penyimpangan Perilaku Chuugi}

Setiadi (2011: 215-227) mengemukakan bahwa terdapat beberapa faktor yang dapat menyebabkan terjadinya penyimpangan perilaku, yang dalam hal ini akan dijadikan dasar untuk menganalisis penyebab penyimpangan perilaku chuugi. Faktorfaktor penyebab penyimpangan tersebut yaitu:

(1) Sikap mental yang tidak sehat,

(2) Ketidak harmonisan dalam rumah tangga,

(3) Pelampiasan rasa kecewa,
(4) Dorongan kebutuhan ekonomi,

(5) Pengaruh lingkungan dan media massa,

(6) Keinginan untuk dipuji,

(7) Proses belajar yang menyimpang,

(8) Ketidaksanggupan menyerap norma,

(9) Proses sosialisasi nilai-nilai subkultur menyimpang,

(10) Kegagalan dalam proses sosialisasi,

(11) Adanya ikatan sosial yang berlainan.

\section{METODOLOGI PENELITIAN}

Sumber data dalam penelitian ini berupa dialog yang dikaji secara kualitatif. Menurut Moleong (2010), penelitian kualitatif merupakan penelitian yang bermaksud untuk memahami fenomena tentang apa yang dialami oleh subjek penelitian misalnya perilaku, persepsi, motivasi, tindakan, dll. secara holistik, dan dengan cara deskripsi dalam bentuk kata-kata dan bahasa, pada suatu konteks khusus yang alamiah dan dengan memanfaatkan berbagai metode alamiah. Penelitian ini juga bertujuan untuk mendeskripsikan tindakan yang mencerminkan chuugi dan yang menyimpang dari chuugi dalam 25 data dialog. Sumber data penelitian ini diambil dari dialog yang terdapat pada film animasi Sengoku Musou episode 1 hingga episode 5.

\section{HASIL DAN PEMBAHASAN}

Berdasarkan hasil penelitian ini, ditemukan 25 data dialog yang diklasifikasikan menjadi 2, yaitu; nilai chuugi pada film animasi Sengoku Musou, serta penyimpangan nilai chuugi pada film animasi Sengoku Musou.

\section{Nilai Chungi pada Film Animasi Sengoku Musou}

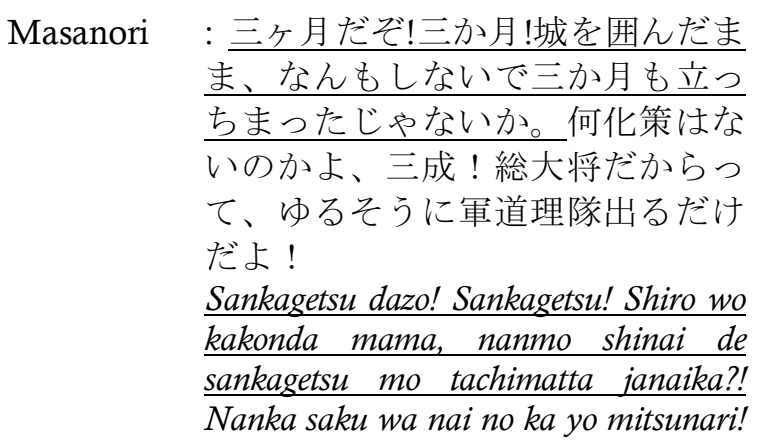


Soudaisho dakara tte, yurusou ni gundoritai deru dake da yo!

'Sudah tiga bulan! Tiga bulan! Kita telah mengepung kastil dan tidak melakukan apapun selama tiga bulan! Apakah tidak ada yang bisa kita lakukan? Mitsunari, jangan hanya duduk di situ hanya karena kau komandan tertinggi!'

Kiyomasa : 落ち着け、正則。

Ochitsuke Masanori.

'Tenangkan dirimu, Masanori.'

Masanori : あの頭で勝つには戦ってもんが割 ってないんだよ! 最初の戦で域に 攻めを落とすしだら。

Ano atama dekazu ni wa ikusa tte mon ga wakatte naindayo! Saisho no ikusa de iki ni seme wo otosu shitara.

'Dia tak paham masalah perang! Kalau saja kita bisa mengambil alih kasti pada serangan pertama.'

(SM: Ep. 1, 04.41 - 05.02)

Pada keluhan Masanori, terutama pada kalimat「三ヶ月だぞ!三か月!城を囲んだまま、 なんもしないで三か月も立っちまったじやない か。」 yang berarti "Sudah tiga bulan! Tiga bulan! Kita telah mengepung kastil dan tidak melakukan apapun selama tiga bulan!", dapat diketahui bahwa pasukan di bawah komando Mitsunari diperintahkan untuk tidak melakukan penyerangan dengan tidak melakukan apapun setelah mengepung kastil. Secara tidak langsung, pasukan yang dikomandoi Mitsunari menjalankan apa yang diperintahkan oleh Mitsunari, termasuk Masanori sendiri. Sebagai seorang prajurit, mematuhi perintah sang pemimpin adalah hal wajib, sehingga kepatuhan yang dilakukan Masanori dan pasukan lainnya sesuai dengan nilai chuugi.

$\begin{array}{ll}\text { Yukimura } & \text { : 清正どのと正則どのは城を出られ } \\ & \text { たそうです。 } \\ & \text { Kiyomasa dono to Masanori dono wa } \\ & \text { shiro wo derareta sou desu. } \\ & \text { 'Sepertinya tuan Kiyomasa dan tuan } \\ & \text { Masanori sudah meninggalkan } \\ & \text { kastil.' } \\ \text { Kanetsugu } & \text { : そうか。三成は、秀吉様の死よ誰 } \\ & \text { より悲しんでいる。 } \\ & \text { Souka. Mitsunariwa Hideoyshi sama no } \\ & \text { shiyo dare yori kanashinde iru. }\end{array}$

'Begitu ya? Mitsunari lebih terpukul dengan kematian tuan Hideyoshi dibanding yang lainnya.'

Yukimura : はい。且つつて、われらが仕えた 武田家は親方さまの死とともに滅 びました。三成どのは豊臣を操作 せぬために力を尽くされているの ですね。

'Hai. Katsu tte warera ga tsukaeta takedake wa oyakata sama no shito tomoni horobimashita. Mitsunari dono wa toyotomi wo sou sasenu tameni chikara wo tsukusarete iru no desune.' 'Benar. Dulu, klan Takeda yang kami layani, hancur bersama dengan meninggalnya tuan kami. Tuan Mitsunari pasti sedang memikirkan cara agar hal serupa tidak terjadi pada klan Toyotomi.'

(SM: Ep. 2, 11.58-12.19)

Pada pernyataan Yukimura, terutama pada kalimat「三成どのは豊臣を操作せぬために力 を尽くされているのですね。」 yang berarti "Tuan Mitsunari pasti sedang memikirkan cara agar hal serupa tidak terjadi pada klan Toyotomi", disebutkan secara tersirat bahwa Mitsunari sedang mencari cara untuk mempertahankan klan Toyotomi untuk memenuhi wasiat mendiang Hideyoshi. Dalam hal ini, tindakan Mitsunari menggambarkan prajurit yang berusaha memenuhi perintah dari sang pimpinan, sehingga hal tersebut sejalan dengan nilai chuugi.

Kanetsugu : 三成は一人で豊臣を背負う覚悟だ。 一人で背負うには重過ぎるにだ。

Mitsunari wa hitori de Toyotomi wo seo kakugo da. Hitori de seo ni wa omosugiru ni da.

'Mitsunari sudah siap untuk menanggung semua beban klan Toyotomi sendirian. Namun, menanggungnya sendiri akan terlalu berat baginya.'

Yukimura : 三成殿一人に、背負わせません。 Mitsunari dono hitori ni wo seo wasemasen.

'Aku tak akan membiarkan tuan Mitsunari menanggungnya sendiri.'

(SM: Ep. 2, 12.20-12.32)

Pada pernyataan 「三成殿一人に、背負わせ ません。」 yang berarti “Aku tak akan 
membiarkan tuan Mitsunari menanggungnya sendiri", dapat diketahui bahwa Yukimura mengetahui beban yang dipikul oleh Mitsunari. Sebagai bawahan dari klan Toyotomi dan sebagai orang yang dekat dengan Mitsunari, Yukimura berusaha untuk tidak membiarkan Mitsunari memikul beban tersebut sendirian. Hal tersebut menggambarkan prajurit yang berusaha berada di sisi sang pimpinan apapun yang terjadi, sehingga pernyataan Yukimura sejalan dengan nilai chuugi.

\section{Penyimpangan Nilai Chuugi pada Film Animasi Sengoku Musou}

\begin{tabular}{|c|c|}
\hline Yukimura & : 共に参りましょう、兄上。 \\
\hline & Tomo ni mairimashou, ani ue. \\
\hline & 'Ayo kita bertarung bersama, kakak.' \\
\hline Nobuyuki & :その書状は受け取れぬ。 \\
\hline & Sono shojou wa uketorenu. \\
\hline & 'Aku tak bisa menerima surat itu.' \\
\hline Yukimura & : 兄上。 \\
\hline & Ani uе. \\
\hline & 'Kakak.' \\
\hline Nobuyuki & : 幸村、私は徳川につく。 \\
\hline & Yukimura, watashi wa Tokugawa ni \\
\hline & tsuku. \\
\hline & 'Yukimura, aku memilih berpihak \\
\hline Yukimura & $\begin{array}{l}\text { pada klan 10Kugawa. } \\
\text { :なぜ?なぜです、兄上？！ }\end{array}$ \\
\hline & Naze? Naze desu, ani ue?! \\
\hline & Kenapa, kaka \\
\hline
\end{tabular}

(SM: Ep. 2, 19.25-19.48)

Pada pernyataan「幸村、私は徳川につく。 \lrcorner yang berarti "Yukimura, aku memilih berpihak pada klan Tokugawa", dapat diketahui bahwa Nobuyuki secara langsung mengatakan bahwa dirinya memihak klan Tokugawa, bukan kepada klan Toyotomi. Sebagai seorang prajurit, memihak kepada lawan adalah hal yang tabu. Dalam hal ini, Nobuyuki yang sebelumnya merupakan bawahan dari klan Toyotomi, memilih untuk memihak kepada klan Tokugawa, sehingga pernyataan Nobuyuki dianggap menyimpang dari nilai chuugi. Faktor depresi atas kehilangan sosok Shingen Takeda membuatnya memilih untuk membela kubu Tokugawa yang masih memiliki sosok penting, yaitu Ieyasu.

\footnotetext{
Nobuyuki ：上田城攻め入るというのは誠でご ざいますか?

Ueda jou seimeiru to iu no wa makoto de gozaimasuka?
}

'Apakah benar anda akan menyerang kastil Ueda?'

Hidetada : ${ }^{*} \mathrm{hmph}^{*}$

Nobuyuki : 今一度を考え直しよ。われらの任 務は被告も早く関ヶ原に到着する こと。上田城を卯攻め入ることで はございません。

Ima ichido wo kangae naoshiyo. Warera no ninmu wa hikoku mo hayaku Sekigahara ni tochaku suru koto. Ueada jou wo seimeiru koto dewa gozaimasen.

'Tolong pertimbangkan sekali lagi. Misi kita adalah agar sampai di Sekigahara secepat mungkin. Bukan menyerang kastil Ueda.'

Hidetada : お前は弟かばっているだけでやろ う。

'Omae wa otouto kabatte iru dake de yarou.'

'Kau hanya ingin melindungi adikmu saja.'

(SM: Ep. 3, 07.00 - 07.23)

Pada pernyataan「われらの任務は被告も早 く関ヶ原に到着すること。上田城を卯攻め入る ことではございません。」 yang berarti “Misi kita adalah agar sampai di Sekigahara secepat mungkin. Bukan menyerang kastil Ueda", dapat diketahui bahwa Hidetada ditugaskan memimpin pasukan untuk secepatnya menuju Sekigahara, bukan untuk menyerang Kastil Ueda. Dalam pernyataan Nobuyuki, Hidetada dirasa lalai dalam melaksanakan tugasnya. Melalaikan tugas merupakan tindakan tidak patuh terhadap pemimpin. Hal tersebut merupakan penyimpangan dari nilai chuugi. Seharusnya seorang prajurit harus mengedepankan tugas yang ia terima sebagai bentuk kesetiaan. Faktor psikopati dimana kebenciannya terhadap klan Sanada mendorong keinginannya untuk menyerang kastil Ueda.

Nobuyuki : 秀忠さま、おやめください。家康 様よりお扱いしている大臣な武器 代役です。

Hidetada sama, oyame kudasai. Ieyasu sama yori oatsukare shiteiru daijinna buki dain yaku desu.

'Tuan Hidetada, tolong hentikan ini. Tuan Ieyasu mempercayakan senjata dan amunisi yang berharga pada kita.' 
Hidetada : あの手どの城を落とすのに対して そう思わせぬ。お前は口を出すな。 Ano te dono shiro wo otosu noni taishite sou omowasenu. Omae wa kuchi wo dasu na.

'Aku tak menggunakannya secara berlebihan hanya untuk sebuah kastil seperti itu. Lebih baik kau diam saja.'

(SM: Ep. 320.21 - 20.36)

Pada pernyataan Nobuyuki「秀忠さま、おや めください。家康様よりお扱いしている大臣な 武器代役です。」 yang berarti “Tuan Hidetada, tolong hentikan ini. Tuan Ieyasu mempercayakan senjata dan amunisi yang berharga pada kita", dapat diketahui bahwa Hidetada menggunakan persenjataan yang Ieyasu percayakan kepadanya. Penggunaan senjata tersebut juga tanpa sepengetahuan Ieyasu dan Hidetada sudah menyalahi tugasnya yaitu membawa persenjataan menuju Sekigahara. Hidetada dianggap tidak mengedepankan tugas yang diberikan oleh Ieyasu selaku pimpinan, sehingga hal tersebut dianggap menyimpang dari nilai chuugi. Faktor mencari pelampiasan rasa kecewa karena tidak bisa menembus Kastil Ueda mendorong Hidetada untuk melakukan penyimpangan tersebut.

\section{KESIMPULAN}

Kesimpulan mengenai nilai chuugi pada film animasi Sengoku Musou dapat diketahui dari sikap yang tercermin pada potongan dialog dari beberapa karakter. Terdapat 20 data dialog yang menunjukkan sikap chuugi pada film animasi Sengoku Musou. Diketahui adanya 3 aspek yang mencerminkan nilai chuugi, yaitu: aspek kepatuhan terhadap perintah tuannya, tetap bersama dengan tuannya apapun yang terjadi dan rela mengorbankan segalanya untuk tuannya. Selain itu, ditemukan pula 5 data yang menunjukkan penyimpangan nilai chuugi pada film animasi Sengoku Musou. Tindakan penyimpangan tersebut terlihat dari aspek ketidak-patuhan terhadap perintah tuannya dan pengkhianatan terhadapat tuannya. Penyimpangan tersebut terjadi dikarenakan beberapa faktor yaitu faktor ekonomi, faktor depresi, faktor psikopati, faktor mencari pelampiasan rasa kecewa dan faktor ikatan sosial yang berlawanan.

\section{DAFTAR PUSTAKA}

Agustian, A.G. (2010). Spiritual Samurai. Arga Tilanta: Jakarta.

Moleong, L. J. (2010). Metodologi Penelitian Kualitatif. Remaja Rosdakarya: Bandung.

Nitobe, I. (1908). Bushido: The Soul of Japan. Teibi Publishing Company: Tokyo.

Notoatmodjo, S. (1993). Pengantar Pendidikan Kesehatan dan Ilmu Perilaku Kesehatan. Andi Offset: Yogyakarta.

Notoatmodjo, S. (2010). Ilmu Perilaku Kesehatan. Rineka Cipta: Jakarta.

Rahayuningtyas, P. (2016). Bentuk Nilai Bushido Dalam Novel Saga No Gabai Baachan Karya Shimada Yoshichi. Jurnal Diglossia, 7(2), 50-60. https://doi.org/10.26594/diglossia.v7i2.568

Rahmah, Y. (2018). Nilai-Nilai Bushido Dalam Minwa. Jurnal Kiryoku, 2(1), 1-10. https://doi.org/10.14710/kiryoku.v2i1.1-10

Seruni, A. P. (2018). Kajian Sosiologi Sastra Nilai-Nilai Bushido Tokoh Utama pada Novel Toyotomi Hideyoshi no Keieijyuku Karya Kitami Masao. Jurnal Bahtera-Jurnal Pendidikan Bahasa, Sastra dan Budaya, 5(9), 248-271. https://doi.org/10.37729/btr.v5i9.4820

Setiadi, E. M. \& Usman, K. (2010). Pengantar Sosiologi; Pemahaman Fakta dan Gejala Sosial, Teori, Aplikasi, dan Pemecahannya. Kencana Prenada Media: Jakarta.

Sulaeman, M. M. (1998). Ilmu Budaya Dasar: Suatu Pengantar. Refika Aditama: Jakarta.

Widagdho, D. (2010). Ilmu Budaya Dasar. Bumi Aksara: Jakarta.

Widyosiswoyo, S. (2004). Ilmu Budaya Dasar. Ghalia Indonesia: Bogor.

Wulandari, S. (2017). Moral Bushido Dalam Karya Masaoka Shiki. Ayumi: Jurnal Budaya, Bahasa, Dan Sastra, 4(1), 46-62. doi: http://dx.doi.org/10.25139/ayumi.v4i1.546 


\title{
The Use of Japanese Personal Pronoun based on Gender in "Narcissu" by Tomo Kataoka
}

\author{
Hadiid Hideo Nusantara \\ Universitas Padjadjaran, Bandung, Indonesia \\ hadiidhideo8@gmail.com
}

\begin{abstract}
A B S T R A C T
This article discussed the difference of Japanese pronouns based on gender from literature point of view. The database of this study was a novel entitled "Narcissu" by Japanese author Tomo Kataoka. The research method used in this research was descriptive method. In analysing the novel, author used the morphology theories by Harumi Tanaka (1982). The findings of this study showed that the use of personal pronoun including first-person pronouns, second-person pronouns, and thirdperson pronouns in the novel were influenced greatly by gender. The difference in using these personal pronouns were caused by the difference in man and woman's perception. Based on the data, there were tendency that the speakers choose the best word to utter to their interlocutor based on their own perspective, influenced by the situation and the context. The findings of this study was expected to help foreign language learners to understand better about the use of Japanese personal pronoun based on gender, mainly in conversation.
\end{abstract}

Gender; Language variety; Morphology; Personal Pronoun

\section{K E Y W O R D S}

$\begin{array}{lrr} & \text { A R T I C L E I N F O } & \text { First received: } 18 \text { December } 2019 \\ \text { Final proof accepted: } 15 \text { May } 2020\end{array}$

Available online: 20 June 2020

\section{PENDAHULUAN}

Bahasa Jepang sangat dipengaruhi oleh faktorfaktor luar bahasa, seperti faktor situasional, sosial, stratifikasi, ekonomi, umur, dan gender. Faktor gender yang mengakibatkan terjadinya perbedaan variasi bahasa yang terlihat di dalam penutur pria dan penutur wanita. Gender pada penelitian ini merujuk kepada bahasa yang khusus digunakan oleh pria yang disebut "danseigo" (男性語) dan bahasa yang khusus digunakan oleh wanita yang disebut "joseigo" (女性語). Hal ini disebabkan karena pada kenyataannya, bahasa Jepang tidaklah memiliki sistem gender dalam kategori gramatikal seperti halnya bahasa Perancis maupun bahasa sejenis lainnya.

Nomina, atau dalam bahasa Jepang disebut meishi (名詞), adalah kategori yang secara sintaktis tidak dapat bergabung dengan morfem "tidak", tetapi dapat didahului oleh "dari", dan dari segi semantis, nomina adalah kata yang merujuk pada nama seseorang, tempat, atau semua benda dan segala yang dibendakan (Kridalaksana, 1992). 
Menurut Sudjianto dan Dahidi (2012), nomina terbagi atas lima kelompok, yaitu:

1. Nomina umum (Futsuumeishi) merupakan nomina yang menyatakan nama-nama benda, barang, peristiwa, dan sebagainya yang bersifat umum. Misalnya 山 (yama) 'gunung', 本 (hon) 'buku', 学校 (gakkou) 'sekolah', 世界 (sekai) 'dunia', dan 星 (hoshi) 'bintang'.

2. Nomina diri (Koyuumeishi) merupakan nomina yang menyatakan nama-nama yang menunjukkan benda secara khusus seperti nama-nama daerah, nama-nama negara, nama orang, nama buku, dan sebagainya. Misalnya 太平洋 (Taiheiyou) 'Samudera Pasifik', インド ネシア (Indonesia), 日本 (Nihon) 'Jepang', 富 士山 (Fujisan) 'Gunung Fuji', 韓国 (Kankoku) 'Korea'.

3. Nomina formal (Keishikimeishi) merupakan nomina yang menerangkan fungsinya secara formalitas tanpa memiliki hakekat atau arti yang sebenarnya sebagai sebuah nomina. Menurut Murata (dalam Rini, 2018), keishiki meishi adalah nomina yang digunakan untuk memodifikasi kata yang lain dan nomina yang hampir tidak digunakan secara tunggal yang memiliki arti substansial, misalnya: こと (koto), ため (tame), わけ (wake), はず (hazu), まま (mama), とおり (toori), 場合 (baai), dan sebagainya.

4. Nomina numeral (Suushi) merupakan nomina yang menyatakan bilangan, jumlah, kuantitas, urutan dan sebagainya. Misalnya 三つ (mitsu) 'tiga', 七人 (shichi nin) 'tujuh orang', 第一 (daiichi) 'pertama', 五本 (gohon) 'lima batang'.

5. Pronomina (Daimeishi) merupakan nomina yang menunjukkan sesuatu tanpa menyebutkan nama orang, benda, barang, perkara, arah, tempat, dan sebagainya. Katakata yang dipakai untuk menunjukkan orang disebut dengan ninshou daimeishi (pronomina persona), sedangkan kata-kata yang dipakai untuk menunjukkan benda, barang, perkara, arah, dan tempat disebut dengan shiji daimeishi (pronomina penunjuk). Misalnya この (kono) 'ini', その (sono) 'itu', あの (ano) 'itu', これ (kore) 'ini', それ (sore) 'itu', あれ (are) 'itu', ここ (koko) 'di sini'，そこ (soko) 'di situ'，あそこ (asoko) 'di sana', あなた (anata) 'kamu', わたし (watashi) 'saya', かのじょ (kanojo) 'dia', dan sebagainya.
Akan tetapi, ada sedikit tambahan jenis kata nomina yang ada pada bahasa Jepang, yaitu:

1. Nomina Abstrak (Chuushoumeishi) di mana nomina bersifat abstrak seperti 命 (inochi) 'jiwa', 平和 (heiwa) 'kedamaian', dan sebagainya.

2. Nomina keterangan (Tenseimeishi) di mana kelas kata lain selain nomina diproses menjadi nomina (nominalisasi), contohnya adalah 滅び (horobi) 'kehancuran', 嬉 しさ (ureshisa) 'kesenangan', dan sebagainya.

Alwi, Soenjono, Lapoliwa, dan Moeliono (2003) menyebutkan bahwa sebagian besar pronomina persona bahasa Indonesia memiliki lebih dari dua wujud. Hal ini disebabkan oleh adanya budaya bangsa kita yang sangat memperhatikan hubungan sosial antar manusia. Tata krama dalam kehidupan bermasyarakat kita menuntut adanya aturan yang serasi dan sesuai dengan martabat masing-masing. Berbagai jenis Pronomina Persona adalah sebagai berikut.

1. Persona Pertama

Pronomina persona pertama adalah pronomina yang mengacu pada diri sendiri. $\mathrm{Di}$ samping pronomina persona pertama tunggal juga ada pronomina persona pertama jamak.

2. Persona Kedua

Pronomina persona kedua adalah pronomina yang mengacu pada orang yang diajak bicara. Pronomina persona kedua ini ada yang mengacu pada banyak orang dan ada yang mengacu pada hanya satu orang. Pronomina persona yang mengacu pada satu orang disebut dengan pronominal persona kedua tunggal, dan pronomina persona kedua yang mengacu pada banyak orang disebut dengan pronomina persona kedua jamak.

3. Persona Ketiga

Pronomina persona ketiga adalah pronomina yang mengacu pada orang yang dibicarakan. Pronomina persona ketiga ini juga ada yang mengacu pada banyak orang dan ada yang mengacu pada hanya satu orang. Pronomina persona yang mengacu pada satu orang disebut dengan pronomina persona ketiga tunggal. Pronomina persona ketiga yang mengacu pada banyak orang disebut dengan pronomina persona ketiga jamak.

Sama seperti bahasa Indonesia, pronomina persona dalam bahasa Jepang juga terbagi ke dalam tiga jenis, yaitu kata ganti orang pertama 
yang disebut ichininshou daimeishi, kedua yang disebut nininshou daimeishi dan ketiga yang disebut sanninshou daimeishi. kata ganti orang pertama yaitu, saya (watashi/ washi/ware), aku (ore/boku) (singularis), kami (watashitachi/bokura/wareware) (pluralis), dan kita (pluralis: orang kedua ikut serta) (bahasa Jepang tidak membedakan antara "kami" dan "kita"); kata ganti orang kedua, yaitu "anda" (anata/nanji), "kamu" (omae), "engkau" (kimi) (singularis), dan "kalian" (anatatachi/omaera) (pluralis); serta kata ganti orang ketiga, yaitu "orang itu" (ano hito), "dia (laki-laki/perempuan)" (kare/kanojo) (singularis), dan "mereka" (anohitotachi/karera) (pluralis).

Tanaka (1982) membagi kosa kata yang digunakan berdasarkan gender ke dalam 4 bagian, yaitu joseigo (Bahasa Perempuan), danseigo (Bahasa Laki-laki), tsuuseigo (Bahasa Umum), dan chuuseigo (Bahasa Netral). Namun dalam bahasa Jepang tidak ada bahasa netral. Pembentukkan kata gender pun pada umumnya bukan karena adanya makna leksikal melainkan karena adanya makna gramatikal.

Jorden (dalam Sudjianto \& Dahidi, 2004) menyatakan bahwa bahasa Jepang memiliki karakteristik berupa adanya gaya bahasa yang secara tegas membedakan jenis kelamin. Danseigo merupakan ragam bahasa yang secara khusus digunakan oleh laki-laki. Misalnya ore (aku) dan omae (kamu). Sedangkan joseigo adalah ragam bahasa yang secara khusus digunakan oleh kaum wanita. Akan tetapi menurut Takamizawa (dalam Sudjianto \& Dahidi, 2004), pada situasi formal hampir tidak ada perbedaan antara laki-laki dan wanita.

Penelitian yang dilakukan oleh Yuana (2018) mengenai perbedaan pronomina persona pertama berdasarkan gender memberikan banyak contoh penggunaan pronomina yang ada pada bahasa Jepang. Salah satunya seperti contoh berikut.

\section{私は自動車に泥水をかけられた。}

Watashi wa jidousha ni doromizu o kakerareta.

'Saya tersiram genangan air kotor oleh mobil lewat.

(Yukiko, 1989, hal.21 dalam Yuana, 2018)

Pada contoh kalimat di atas, watashi digunakan untuk menunjuk dirinya sendiri tanpa bermaksud untuk merendahkan diri atau meninggikan orang lain, karena kata watashi bersifat umum dan lazim digunakan dalam semua situasi, baik situasi formal maupun informal, dan bisa digunakan pada semua kalimat baik kalimat tanya, kalimat berita dan sebagainya.

Penelitian di atas sangat membantu dalam mempelajari penggunaan kalimat bahasa Jepang bagi penutur asing. Tetapi, penelitian tersebut hanya memberikan penjelasan terhadap pronominal persona pertama saja, sedangkan dalam bahasa Jepang pronomina persona terbagi atas tiga sudut pandang. Maka dari itu, penelitian ini diharapkan dapat mengisi kekosongan yang ada di penelitian terdahulu, agar dapat meningkatkan penelitian dalam bidang kebahasaan ke jenjang yang lebih tinggi.

Penelitian ini menggunakan novel sebagai data primer. Penggunaan novel sebagai data disebabkan oleh kerelevansian yang tercerminkan oleh novel, sangat berkaitan dengan dunia nyata. Menurut Luxemburg (1989) dalam Artika (2015) karya sastra bisa mencerminkan kenyataan, sastra sering juga dituntut agar mencerminkan atau merepresentasikan kenyataan. Paparan tersebut menunjukkan bahwa karya sastra merupakan cerminan fenomena sosial yang terjadi karena proses pembuatannya tidak terlepas dari referensireferensi sosial yang ditemui pengarangnya di dunia nyata dan dituangkannya dalam karya tersebut.

Light novel karya Tomo Kataoka yang berjudul "Narcissu" adalah sebuah novel ringan yang menceritakan dua orang pasien rumah sakit yaitu Yuu Atou dan Setsumi Sakura yang telah masuk ke L7 (lantai 7) sebuah rumah sakit, dan diketahui bahwa hidup mereka tidak akan lama lagi. Setsumi tidak ingin mengakhiri hidupnya di rumah sakit maupun di rumahnya sendiri. Salah satu contoh yang menarik perhatian peneliti terhadap novel ini adalah banyaknya penggunaan pronomina persona yang tercermin di dalam teks novel tersebut. Salah satunya pada contoh berikut.

\footnotetext{
俺の名前や血液型が記載された、そのいろが青か ら白へと変わった。

Ore no namae ya ketsueki ga kisai sareta, sono iro ga ao kara shiro e to kawatta.
}

(Kataoka, 2008, hal. 28)

俺/の/名前/や/血液型/が/記載された、/その いろ/が/青/から/白/へと/変わった。

Saya/ par/ nama/ dan/ gol.darah/ par/ dicatat/ warna itu/ Par/ biru/ par (dari)/ putih/ par (ke)/ berubah

'Nama dan gol. Darah saya dicatat, warna (gelangnya) berubah dari biru ke putih.'

(Kataoka, 2015, hal. 23) 
Kalimat ini merupakan monolog Yuu pada pembukaan cerita (prolog) yang menceritakan bahwa setelah kepindahannya ke Rumah Sakit, banyak hal yang mulai berubah pada dirinya. Akhirnya setelah didiagnosis bahwa dia harus pindah ke RS yang lebih modern agar kasusnya dapat ditangani dengan lebih baik. Gelang identitas yang ia gunakan pun berbeda dengan yang biasa ia gunakan sebelumnya.

Pada kalimat ini, Yuu menggunakan ore. Kata ganti orang pertama ini terkesan kasar dan menampilkan keakraban yang umumnya digunakan oleh pria usia remaja hingga orang tua terhadap teman atau terhadap orang yang statusnya lebih rendah.

Dari contoh kalimat di atas, kita dapat melihat bahwa gender merupakan salah satu faktor dominan dalam pemilihan kata pronomina persona. Dengan adanya penelitian terdahulu oleh Yuana (2018) mengenai perbedaan pronomina persona pertama berdasarkan gender dan penelitian Hermawan dan Rosliana (2013) mengenai penggunaan pronomina persona dalam bahasa Jepang, peneliti ingin memberikan khasanah yang lebih mendalam dalam penelitian linguistik morfologi yang fokus kepada cerminan percakapan sehari-hari masyarakat Jepang dalam sebuah karya sastra. Ini yang menjadi daya tarik bagi peneliti untuk melihat bagaimana fenomena variasi pronomina persona ini digambarkan dalam novel.

\section{METODE PENELITIAN}

Penelitian ini merupakan penelitian pustaka. Data yang digunakan berupa data primer dari novel "Narcissu" karya Tomo Kataoka berupa penggalan kalimat yang menggunakan kelas kata pronomina persona pada setiap percakapan maupun monolog pada novel. Novel tersebut dianalisis menggunakan metode deskriptif kualitatif dengan pendekatan morfologi, di mana tiap-tiap kata dipusatkan dan diperhatikan pada prinsip-prinsip umum yang mendasari perwujudan satuan-satuan gejala yang ada. Teknik yang digunakan dalam proses analisis adalah mencatat keterangan-keterangan melalui hasil pembacaan novel yang menunjukkan fenomena penghilangan pronomina agar munculnya percakapan yang implisit. Teori yang digunakan sebagai landasan dalam menganalisis adalah teori morfologi sebagai jembatan dalam pengkategorian kata dalam struktur kalimat, agar dapat mengkaji lebih lanjut mengenai terjadinya penghilangan atau pergeseran yang terjadi pada bahasa Jepang dengan hasil dari terjemahan bahasa Indonesia.

\section{HASIL DAN PEMBAHASAN}

\section{Kata Ganti Orang Pertama (Ichininshou Daimeishi)}

Penggunaan kata ganti orang pertama biasa digunakan untuk menunjuk pembicara yang menuturkan kalimat mereka. Penggunaan kata ganti ini merujuk kepada kata "aku", "saya" dan lainnya untuk menunjukkan identitas subjek dari kalimat yang dituturkan. Sebagai contohnya:

Data 1:

こんな時こそ、わたしも笑顔を向け、明るく振る 舞うべきかも知れないけど.......本当はあまり好き じゃなかったポテトを黙って食べるぐらいしかで きなかった。

Konna toki koso, watashi mau egao wo muke, akaruku maubeki kamo shirenai kedo... hontou wa amari suki janakatta poteto wo damatte taberu gurai shika dekinakatta.

(Kataoka, 2008:16)

こんな/時/こそ、/わたし/も/笑顔/を/向け、/ 明るく/振る舞う/べき/かも知れない/けじ....../ 本当/は/あまり/好き/じやな/かった/ポテト/を /黙って/食べる/ぐらい/しか/できな/かった。

Seperti ini/ waktu/ pastinya/ aku/ par/ senyum/ par/ menunjuk/ ceria/ bersikap/ harus/ mungkin/ tetapi/ benar/ par/ terlalu/ suka/ tidak/ telah/ kentang/ par/ diam/ makan/ hanya/ selain/ tidak bisa/ telah

'Pada saat makan malam yang seperti itu pun, diriku tetap saja berusaha untuk tertawa dan bersikap ceria... Namun, sebenarnya aku hanya bisa diam dan memakan kentang yang tidak begitu kusukai.'

(Kataoka, 2015, hal. 11)

Data 1 di atas merupakan monolog Setsumi saat sedang makan malam bersama kedua orangtuanya di rumah baru. Setsumi yang baru saja didiagnosa bahwa dia memiliki penyakit yang tidak dapat disembuhkan merasa hanya menjadi beban hidup bagi keluarganya. Dia yang ingin dimarahi atas ketidakmampuannya merasa depresi karena tidak dapat melakukan apa-apa. Pada akhirnya dia menyerah dan hanya dapat tersenyum untuk orang tuanya.

Kalimat data ini memiliki kesan feminim dengan penggunaan kata “わたし (watashi)” yang 
memiliki arti 'saya', dan terkesan lebih mendekati joseigo. Penggunaan kata ini memang dapat digunakan oleh kaum pria, tetapi penggunaan kata ini lebih digunakan oleh kaum wanita untuk menunjukkan keformalitasan. Sedangkan kata ganti yang sering digunakan oleh pria untuk menunjukkan keformalitasan adalah “ぼく (boku)". Penggunaan kata feminim lainnya untuk menggantikan orang pertama adalah “わたくし (watakushi)" di mana penggunaan kanjinya sama dengan kata “わたし (watashi)”, yaitu “私”、dan juga kata “あたし (atashi)” sebagai joseigo yang sering digunakan dalam bahasa nonformal. Dengan melihat pronomina persona yang digambarkan, maka kita dapat mengkonfirmasikan bahwa penutur dialog tersebut merupakan orang dengan gender wanita, yaitu Setsumi. Hal ini sesuai dengan situasi yang digambarkan bahwa kalimat ini memang merupakan bagian dari monolog Setsumi.

Pada penelitian Yuana (2018), terdapat penjelasan yang membenarkan hal di atas, bahwa watashi digunakan untuk menunjuk dirinya sendiri tanpa bermaksud untuk merendahkan diri atau meninggikan orang lain, karena kata watashi bersifat umum dan lazim digunakan dalam semua situasi, baik situasi formal maupun informal. Terkait dengan penjelasan tersebut, Yuana (2018) menggunakan contoh sebagai berikut.

Data 2.

私は自動車に泥水をかけられた。

Watashi wa jidousha ni doromizu o kakerareta.

'Saya tersiram genangan air kotor oleh mobil lewat.'

(Yukiko, 1989, hal. 21 dalam Yuana, 2018)

Data 3 di atas menunjuk kepada pemeran wanita yang memanggil dirinya dengan sebutan "watashi" dengan konteks formalitas terhadap lawan bicara yang lebih tinggi kedudukannya. pada contoh tersebut, Yuana (2018) mengungkapkan bahwa watashi biasanya digunakan oleh pria maupun wanita dengan maksud sedikit lebih akrab atau sedikit informal, dan merupakan kata ganti orang pertama tunggal untuk menunjukkan diri sendiri. Tetapi peneliti menganggap bahwa pernyataan tersebut kurang tepat, karena data yang digunakan berkontradiksi dengan pernyataan bahwa kata ini memiliki maksud sedikit lebih akrab. Jika dilihat pada data yang telah diteliti, terlihat bahwa penyebutan watashi di sini memiliki jarak antara penutur dan lawan bicara, sehingga terjadi keformalan di dalam kalimatnya.
Pada contoh selanjutnya kita juga akan melihat bagaimana penggunaan pronomina persona pertama digunakan oleh pria.

Data 3.

俺も他のみんなと同じように、自分のナンバーを 目で追う。

Ore mo hoka no minna to onaji youni, jibun no nambaa wo me de ou.

(Kataoka, 2008, hal. 18)

俺/も/他/の/みんな/と/同じ/ように/自分/の/ ナンバー/を/目/で/追う。

Aku/ par/ lain/ par/ semua/ par/ sama/ seperti/ diri sendiri/ par/ angka/ par/ mata/ par/ mengejar 'Sama seperti orang-orang lainnya, aku pun mulai mencari-cari nomor ujianku.'

(Kataoka, 2015, hal. 13)

Data 3 di atas merupakan monolog Yuu pada saat dia bersama temannya hendak melihat papan buletin ujian mengemudi. Selain Yuu dan temannya, banyak peserta lain yang ikut untuk mencari nomor peserta ujian mereka di papan elektronik yang terpampang. Yuu yang mengikuti ujian mengemudi demi mendapatkan surat izin mengemudinya merasa senang karena dia dan temannya dapat lulus dalam waktu yang bersamaan.

Kalimat data ini memiliki kesan maskulin dengan penggunaan kata “おれ (ore)” yang terkesan lebih mendekati danseigo. Penggunaan kata ini terkesan maskulin karena lebih sering digunakan oleh gender dengan sifat maskulin. Biasanya kaum pria menggunakan kata ini dalam penggunaan bahasa nonformal. Penggunaan kata maskulin lainnya untuk menggantikan orang pertama adalah “ぼく(boku)" yang menggunakan kanji “僕”、kata “わがはい (wagahai)” dengan kanji “吾輩”, “わし (washi)” dengan kanji “儂” sebagai danseigo yang sering digunakan dalam bahasa nonformal, dan”われ (ware)" dengan kanji “我” sebagai danseigo yang sering digunakan dalam bahasa formal. Dapat dipastikan bahwa penutur dialog tersebut merupakan orang dengan gender maskulin, yaitu Yuu. Hal ini sesuai dengan situasi yang digambarkan bahwa kalimat ini memang merupakan bagian dari monolog Yuu.

Penelitian Yuana (2018) juga menegaskan bahwa Ore adalah kata ganti orang pertama yang umumnya digunakan oleh pria usia remaja hingga orang tua terhadap teman sebaya, teman akrab, atau terhadap orang yang lebih rendah statusnya, 
serta memiliki kesan sangat akrab atau bahkan kasar.

\section{Kata Ganti Orang kedua (Nininshou Daimeishi)}

Penggunaan kata ganti orang kedua biasa digunakan untuk menunjuk lawan bicara yang menuturkan kalimat mereka. Penggunaan kata ganti ini merujuk kepada kata "kamu", "anda", "engkau" dan lain sebagainya untuk menunjukkan identitas subjek dari kalimat yang dituturkan.

Data 4.

マキエ、あなたもあの病院に勤めているなら噂く らい聞いたことあるでしょ?

Makie, anata mo ano byouin ni tsutomete iru nara uwasa kurai kiita koto aru desho?

(Kataoka, 2008, hal. 198)

マキエ/あなた/も/あの/病院/に/勤めている/な ら/噂/くらい/聞いた/こと/ある/でしょ

Makie/kamu/ par/ itu/ rumah sakit/ par/ bekerja/ kalau/ rumor/ Cuma/ dengar/ hal/ ada/ kan

'Makie, kalau kamu sudah lama bekerja di RS itu, kamu pasti sudah dengar gosipnya, kan?'

(Kataoka, 2015, hal. 196)

Data 4 merupakan dialog Yuka kepada Makie saat mereka sedang mengejar Yuu dan Setsumi sampai ke Shiga. Di perjalanan, Yuka menceritakan kisah pasien $L 7$ yang pernah kabur seperti Yuu dan Setsumi. Yuka membantu pelarian si pasien yang ternyata merupakan sahabatnya. Yuka menceritakan bahwa pada akhir hayatnya, sahabatnya memberikan mobil pelarian mereka kepadanya, dan mobil itu adalah mobil yang mereka tumpangi sekarang.

Kalimat data ini memiliki kesan feminim dengan penggunaan kata “あなた (anata)” yang terkesan lebih mendekati joseigo. Penggunaan kata ini terkesan feminim karena penggunaan kata ini lebih sering digunakan oleh gender dengan sifat feminim. Hermawan dan Rosliana (2013) mengatakan bahwa benar adanya jika penggunaan "anata" biasa digunakan oleh pria maupun wanita, namun kaum wanita lebih biasa menggunakan kata ini dalam bahasa formal. Bahkan kata ini dianggap lazim dan formal sebagai panggilan oleh kaum wanita kepada suaminya. Hermawan dan Rosliana (2013) juga menegaskan bahwa pronomina anata hanya dapat dipakai saat pertama kali bertemu dengan lawan bicara dalam situasi formal. Berdasarkan paparan tersebut, maka dapat dipastikan bahwa penutur dialog tersebut merupakan orang dengan gender feminim, yaitu Yuka atau Makie. Hal ini sesuai dengan referensi yang telah disampaikan setelah membaca kalimat di atas bahwa penutur merupakan lawan bicara dari Makie, yaitu Yuka.

Pada contoh selanjutnya kita juga akan melihat bagaimana penggunaan pronomina persona kedua digunakan oleh pria.

Data 5.

なあ、お前.......そのテレビ面白いか?

Naa, omae... sono terebi omoshiroi ka?

(Kataoka, 2008, hal. 30)

なあ/お前/その/テレビ/面白い/か

Nah/ kamu/ itu/televisi/ menarik/ par

'Hei, kau... Memangnya acara di TV itu menarik?'

(Kataoka, 2015, hal. 27)

Data 5 di atas merupakan dialog Yuu pada saat dia bertemu dengan Setsumi untuk pertama kalinya. Yuu yang baru saja mendapat kabar bahwa dia harus memasuki RS khusus penyakit kronis, merasa hidupnya telah hancur. Di sana, ia melihat seorang anak kecil terduduk memandangi televisi dengan tatapan kosong. Dia yang merasa harus menegur si gadis akhirnya melontarkan pertanyaan tersebut.

Kalimat data ini memiliki kesan maskulin dengan penggunaan kata “おまえ (omae)” yang terkesan lebih mendekati danseigo. Penggunaan kata ini terkesan maskulin karena penggunaan kata ini lebih sering digunakan oleh gender dengan sifat maskulin, karena biasanya kaum lelaki menggunakan kata ini dalam penggunaan bahasa nonformal. Penggunaan kata maskulin lainnya untuk menggantikan orang pertama adalah “てめ え (temee)” yang menggunakan kanji “手前”、kata “きさま (kisama)” dengan kanji “貴様” yang sering digunakan dalam bahasa nonformal, dan " なんじ (nanji)” dengan kanji “汝” sebagai danseigo yang sering digunakan dalam bahasa formal. Dapat dipastikan bahwa penutur dialog tersebut merupakan orang dengan gender maskulin, yaitu Yuu. Setelah melihat kalimat sebelumnya, “... Kanojo mo onaji tachiba dearu to iu [genjitsu] ga, me no mae ni tatakitsukerareta tame kamoshirenai", kalimat ini merupakan bagian dari monolog Yuu. Maka memang benar bahwa penutur merupakan Yuu yang mulai mengajak bicara gadis yang dimaksud. 


\section{Kata Ganti Orang Ketiga (Sanninshou Daimeishi)}

Penggunaan kata ganti orang ketiga biasa digunakan untuk menunjuk orang lain selain lawan bicara maupun pembicara yang menuturkan kalimat pada dialog mereka. Penggunaan kata ganti ini tidak harus merujuk kepada orang yang tampak oleh penutur maupun lawan bicaranya, melainkan merujuk kepada seseorang yang penutur maupun lawan bicara ketahui tanpa adanya makna abstrak. Penggunaan kata ganti ini merujuk kepada kata "dia", "beliau", penggunaan kata tunjuk terhadap kata benda dengan kata "itu" maupun "ini", dan lain sebagainya untuk menunjukkan identitas subjek dari kalimat yang dituturkan

Data 6.

佐倉さん......あなたはご自分のお娘さんが心配で はないのですか?

Sakura san... anata wa gojibun no omusume san ga shinpai dewa nai no desu ka?

(Kataoka, 2008, hal. 95)

佐倉さん/あなた/は/ご自分/の/お娘さん/が/心 配/ではない/の/です/か

Ibu Sakura/ kamu/ par/ diri sendiri/ par/ anak perempuan/ par/ khawatir/ tidak/ par/ apakah 'Ibu Sakura... Anda nggak mengkhawatirkan putri anda, ya?'

(Kataoka, 2015, hal. 92)

Data 6 di atas merupakan dialog antara Makie dan ibu Setsumi. Makie merasa ibu Setsumi kelihatan tak acuh terhadap anaknya yang hilang bersama dengan Yuu. Makie merasa ibu Setsumi sama dengan ayahnya Yuu yang hanya memikirkan dirinya sendiri, tanpa peduli apa yang terjadi kepada anaknya. Karenanya Makie memberanikan diri untuk melontarkan pertanyaan tersebut.

Kalimat data ini memiliki kesan feminim dengan penggunaan kata “お娘さん (omusumesan)" yang terkesan lebih mendekati joseigo. Penggunaan kata ini terkesan feminim karena lebih sering digunakan oleh Gender dengan sifat feminim. Biasanya kaum wanita menggunakan kata ini dalam penggunaan bahasa formal. Penggunaan kata feminim lainnya juga terlihat pada kata “ご自分 (gojibun)” dan “のです か (no desu ka)" yang sering digunakan dalam joseigo pada bahasa formal. Maka dapat dipastikan bahwa penutur dialog tersebut merupakan orang dengan gender feminim, yaitu Makie dan ibu Setsumi. Hal ini sesuai situasi yang digambarkan di mana kalimat ini memang merupakan bagian dari dialog yang dilontarkan kepada ibu Setsumi oleh Makie. Hal ini diperkuat oleh data penelitian oleh Yuana (2018), bahwa penggunaan prefiks " $O$ " dan "Go" biasa digunakan oleh kaum wanita, memiliki keformalitasan dan tidak terlepas dari sufiks -san yang terkesan formal pula.

Pada contoh 7 kita juga akan melihat bagaimana penggunaan pronomina persona ketiga digunakan oleh pria.

Data 7

ならば頃合いまでどこかで時間を潰している可能 性が高い。

Naraba koroai made dokoka de jikan wo tsubushiteiru kanousei ga takai.

(Kataoka, 2008, hal. 76)

ならば/頃合い/まで/どこか/で/時間/を/潰 している/可能性/が/高い

Maka/ jam pas/ par/ di mana/ par/ di jam/ par/ sedang menghabiskan/ kemugkinannya/ par/ besar 'Kalau begitu, kemungkinan besar pengguna mesin cuci ini pergi ke suatu tempat untuk menghabiskan waktu sampai waktu pengeringan selesai.'

(Kataoka, 2015, hal. 71)

Data 7 merupakan monolog Yuu saat mendatangi area laundry yang dia temukan di pinggir jalan. Yuu sedang melihat keadaan sekitar dan juga bagian dalam toko untuk mengetahui apakah ada orang atau tidak. Dia ingin mengetahui hal ini agar bisa mengetahui apakah rencananya untuk mencuri beberapa pakaian untuk dia dan Setsumi pakai akan berhasil atau sebaliknya. Setelah mengecek semuanya, dia berpendapat bahwa pemilik baju yang ada di dalam mesin cuci sedang tidak ada di tempat.

Kalimat data ini memiliki kesan maskulin dengan penggunaan kata “ならば (naraba)” yang terkesan danseigo. Penggunaan kata ini terkesan maskulin karena penggunaan kata ini bersifat nonformal. Bentuk formal atau yang lebih feminim dari kata tersebut bisa digantikan dengan kata “ですから (desukara)". Dapat dipastikan bahwa yang menuturkan monolog ini adalah orang dengan Gender maskulin, yaitu Yuu.

Dengan Yuu sebagai penutur, penggunaan kata “pengguna mesin cuci" dapat diganti dengan “彼 (kare)”. Penggunaan “彼 (kare)” dianggap lebih tepat karena berdasarkan referensi yang ada, si penutur terbiasa mengunakan kata yang langsung 
menunjuk kepada orang yang dimaksud. Dibandingkan dengan menggunakan bahasa yang berbelit-belit seperti kata “これを使う人 (korewo tsukau hito)" atau “この洗濯機を使う人 (kono sentakuki wo tsukau hito)", Yuu lebih sering terlihat menggunakan kata langsung yang lebih menujukan kepada lawan bicara. Sebagai contoh, "naa, omae... sono terebi omoshiroika?". Dengan referensi tersebut, dapat dikonfirmasikan bahwa kata ganti orang pertama yang akan dituturkan oleh Yuu untuk pengganti kata "pengguna mesin cuci" adalah kare(彼).

Hal ini juga diperkuat dengan penelitian Hermawan dan Rosliana (2018) yang mengatakan bahwa pronomina kare mengacu orang lain yang dibicarakan yaitu pria. Selain itu bisa juga digunakan untuk menyebut kekasih (pria), meskipun bentuk yang lebih lazim digunakan adalah kareshi.

\section{SIMPULAN}

Dengan adanya perbedaan bahasa laki-laki dan perempuan pada contoh kalimat yang telah ditunjukkan, kita dapat menyimpulkan bahwa dalam penggunaan kata ganti orang pertama, kedua, dan ketiga, kata yang digunakan berbeda sesuai gender sang penutur. Kaum wanita terlihat lebih menggunakan kosakata yang lebih halus dibanding kaum pria pada umumnya. Pada pronomina persona pertama dan kedua kaum pria cenderung memilih dan menggunakan kosakata yang terkesan lebih kasar, sedangkan kaum wanita cenderung memilih dan menggunakan kosakata yang terkesan lebih halus. Pada pronomina persona ketiga, kaum wanita lebih cenderung menambahkan awalan " $O$ " atau "Go" di depan meishi yang dimaksudkan untuk menghormati lawan bicara, sedangkan kaum pria cenderung mengabaikan formalitas. Walaupun memiliki perbedaan, tiap-tiap penutur dapat saling memahami satu sama lain. Hal ini terjadi karena tiap gender dapat memahami siapa lawan bicara mereka, dan apa yang harus mereka ucapkan berdasarkan sisi referensi dan juga situasi sehingga mengetahui kata yang tepat untuk dituturkan terhadap lawan bicara dengan perspektif masingmasing. Penelitian ini diharapkan dapat membantu para penutur bahasa asing agar lebih memahami perubahan-perubahan yang terjadi pada pronomina persona pada bahasa Jepang, terutama dalam bahasa percakapan.

\section{REFERENSI}

Alwi, H., Soenjono, D., Lapoliwa, H., \& Moeliono, A. M. (2010). Tata Bahasa Baku Bahasa Indonesia. Jakarta: Balai Pustaka.

Artika, I. W. (2015). Teori dalam Pengajaran Sastra. Prasi: Jurnal Bahasa, Seni dan Pengajarannya, 10(19), 18-27. hhttp://dx.doi.org/10.23887/prasi.v10i19.8850

Hermawan, N., \& Rosliana, L. (2013). Pronomina Persona dalam Novel Naifu dan Terjemahannya dalam Bahasa Indonesia. Japanese Literature, 2(3), 111. Retrieved from eJournal Undip.

Kataoka, T. (2008). Narcissu. Tokyo: Kadokawa Corporation.

Kataoka, T. (2015). Narcissu. (D. Agung, Trans.). Jakarta: PT Eaststar Adhi Citra.

Kridalaksana, H. (1992). Pembentukan Kata dalam Bahasa Indonesia. Jakarta: PT Gramedia Pustaka Utama.

Rini, E. I. H. A. N. (2018). Konjungsi Baai dalam Kalimat Bahasa Jepang. Kiryoku: Jurnal Studi Kejepangan, 2(1), 33-40. https://doi.org/10.14710/kiryoku.v2i1.33-40

Sudjianto, S., \& Dahidi, A. (2012). Pengantar Linguistik Bahasa Jepang. Jakarta: Kesaint Blanc Publishing.

Tanaka, H. (1982). Gengogaku Enshuu. Tokyo: Taishukan Shoten.

Yuana, C. (2018). Perbedaan Ichininsho Daimeishi menurut Gender. Parafrase: Jurnal Kajian Kebahasaan \& Kesastraan, 18(2), 7-18. https://doi.org/10.30996/parafrase.v18i2.1717 

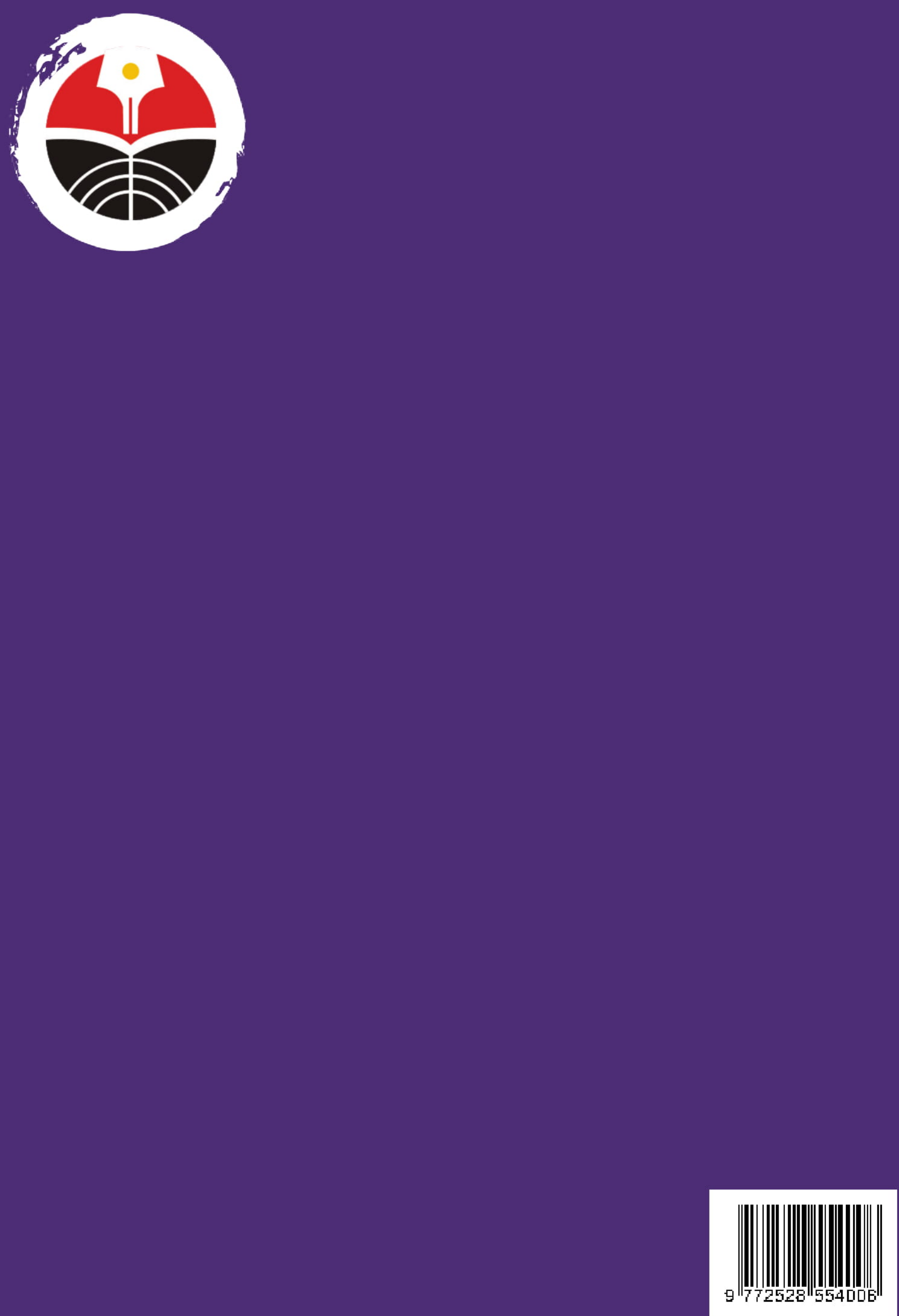